Prepared in cooperation with the Harris-Galveston Subsidence District, the Fort Bend Subsidence District, and the Lone Star Groundwater Conservation District

\title{
Hydrogeology and Simulation of Groundwater Flow and Land-Surface Subsidence in the Northern Part of the Gulf Coast Aquifer System, Texas, 1891-2009
}

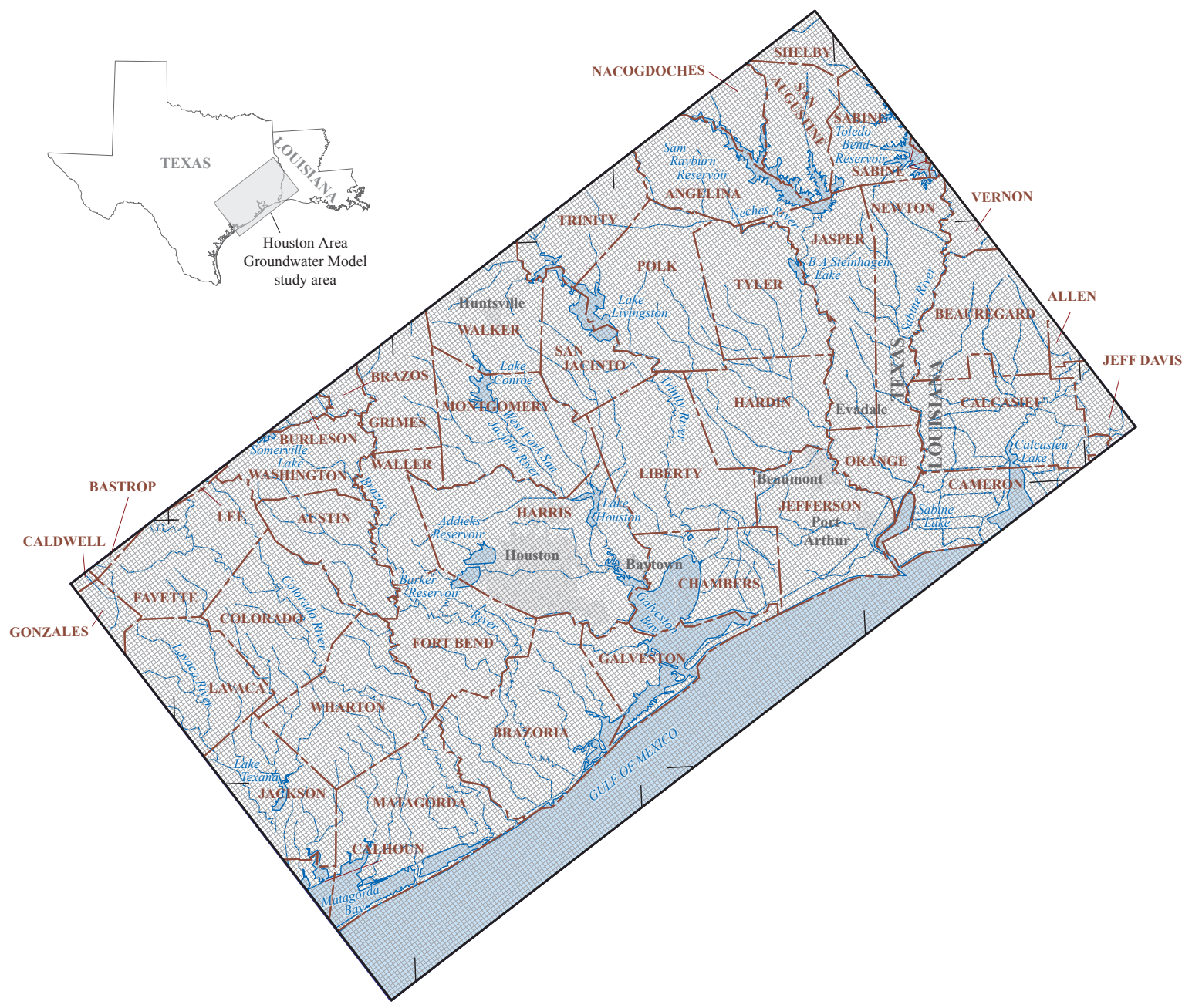

Scientific Investigations Report 2012-5154

Version 1.1, December 2013 



\section{Hydrogeology and Simulation of Groundwater Flow and Land-Surface Subsidence in the Northern Part of the Gulf Coast Aquifer System, Texas, 1891-2009}

By Mark C. Kasmarek

Prepared in cooperation with the Harris-Galveston Subsidence District, the Fort Bend Subsidence District, and the Lone Star Groundwater Conservation District

Scientific Investigations Report 2012-5154

Version 1.1, December 2013 


\title{
U.S. Department of the Interior SALLY JEWELL, Secretary
}

\section{U.S. Geological Survey Suzette M. Kimball, Acting Director}

\author{
U.S. Geological Survey, Reston, Virginia: 2012 \\ Revised: December 2013
}

\author{
This and other USGS information products are available at http://store.usgs.gov/ \\ U.S. Geological Survey \\ Box 25286, Denver Federal Center \\ Denver, CO 80225 \\ To learn about the USGS and its information products visit http://www.usgs.gov/ \\ 1-888-ASK-USGS
}

\begin{abstract}
Any use of trade, product, or firm names is for descriptive purposes only and does not imply endorsement by the U.S. Government.

Although this report is in the public domain, permission must be secured from the individual copyright owners to reproduce any copyrighted materials contained within this report.
\end{abstract}

Suggested citation:

Kasmarek, M.C., 2012, Hydrogeology and simulation of groundwater flow and land-surface subsidence in the northern part of the Gulf Coast aquifer system, Texas, 1891-2009 (ver. 1.1, December 2013): U.S. Geological Survey Scientific Investigations Report 2012-5154, 55 p., http://dx.doi.org/sir20125154.

ISSN 2328-0328 (online) 


\section{Acknowledgments}

The author thanks Robert Gabrycsh (U.S. Geological Survey, retired), Stan A. Leake (U.S. Geological Survey), and Michael J. Turco (formerly with the U.S. Geological Survey) for contributing their insights and expertise on modeling and the mechanism of land-surface subsidence, as well as Jeffery W. East, Michaela R. Johnson, and Barclay W. Shoemaker (U.S. Geological Survey) for assisting with computer programming, modeling, and geographic information system applications. Mike Reedy of Freese and Nichols Inc., John Siefert of LBG-Guyton Associates, and Scott Marr from Fugro-McClelland (Southwest), Inc., provided information pertaining to historical water use, subsidence-related data, and other information helpful during the modeling process. The author also recognizes the Harris-Galveston Subsidence District, the Fort Bend Subsidence District, the Lone Star Groundwater Conservation District, the Texas Water Development Board, and the San Jacinto River Authority for their updated water-use data used in the Houston Area Groundwater Model. Finally, the author would like to thank James Rumbaugh and Doug Rumbaugh of Environmental Simulations, Inc., for their timely updates and modification to their graphical user interface (Groundwater Vistas) used with the MODFLOW-2000 Subsidence and Aquifer-System Compaction package that made the calibration process more efficient. 



\section{Contents}

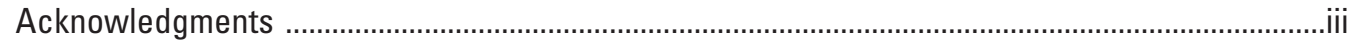

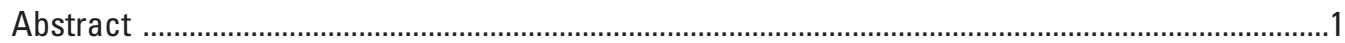

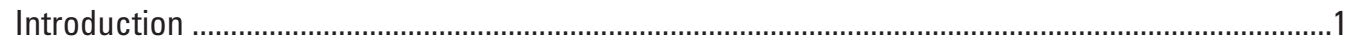

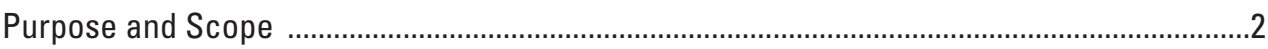

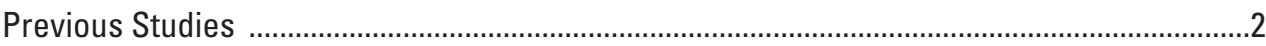

Description of Study Area for the Houston Area Groundwater Model ...................................2

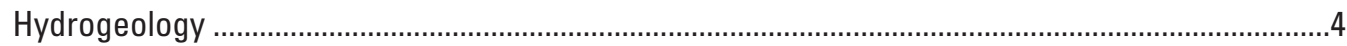

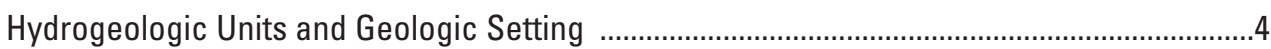

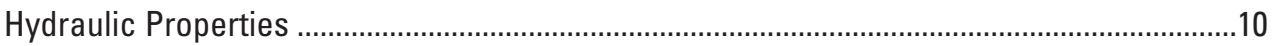

Groundwater Flow Conditions, Recharge, and Discharge ................................................12

Groundwater Development ..........................................................................................

Potentiometric Surfaces and Land-Surface Subsidence ................................................13

Simulation of Groundwater Flow and Land-Surface Subsidence ...............................................14

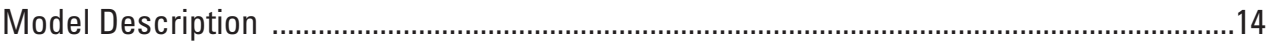

Mathematical Representation .................................................................................

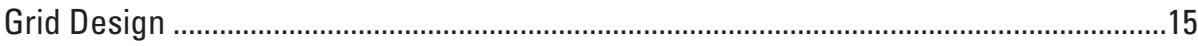

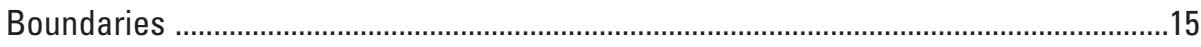

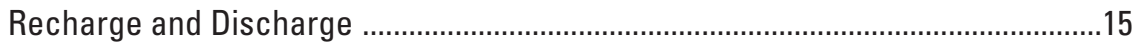

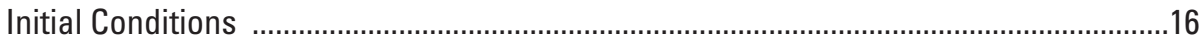

Land-Surface Subsidence and Storage in Clays ..................................................16

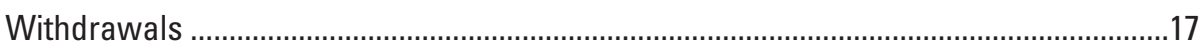

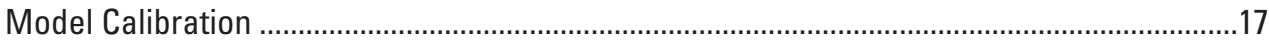

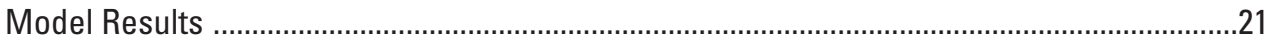

Simulated Hydraulic Properties Associated with Groundwater Flow and

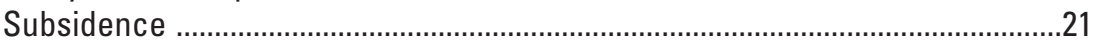

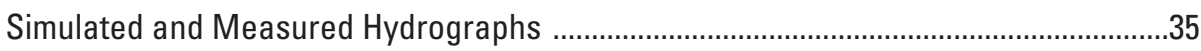

Simulated and Estimated Water-Budget Components ..................................................35

Simulated and Measured Land-Surface Subsidence .......................................................35

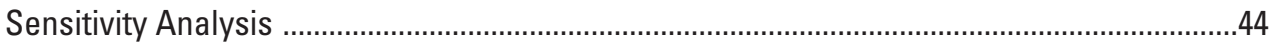

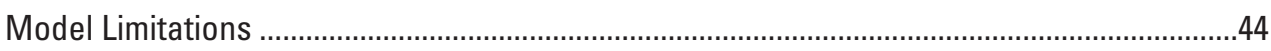

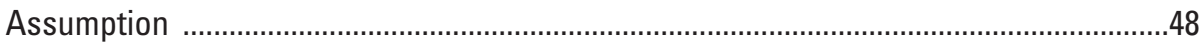

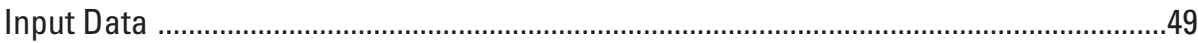

Scale of Application ..................................................................................................

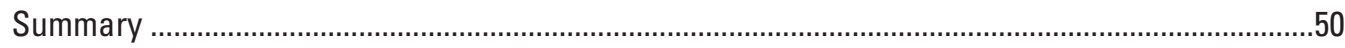

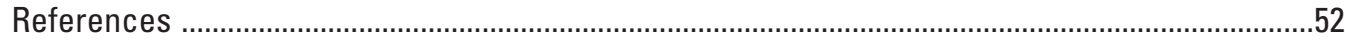

\section{Figures}

1. Map showing location of the Houston Area Groundwater Model study area and finite-difference grid, southeastern Texas and southwestern Louisiana

2. Hydrogeologic section of the Gulf Coast aquifer system in Harris County and adjacent counties, Texas 
3. Correlation of stratigraphic and hydrogeologic units in the Houston Area Groundwater Model study area

4. Map showing extent and outcrop area of the Chicot aquifer in the Houston Area Groundwater Model study area

5. Map showing extent, outcrop area, and subcrop area of the Evangeline aquifer in the Houston Area Groundwater Model study area .

6. Map showing extent, outcrop area, and subcrop area of the Burkeville confining unit in the Houston Area Groundwater Model study area

7. Map showing extent, outcrop area, and subcrop area of the Jasper aquifer in the Houston Area Groundwater Model study area

8. Graph showing total groundwater withdrawals used during transient Houston Area Groundwater Model simulations, by stress periods, 1891-2009

9. Map showing simulated hydraulic conductivity of the Chicot aquifer in the Houston Area Groundwater Model study area

10. Map showing simulated hydraulic conductivity of the Evangeline aquifer in Houston Area Groundwater Model study area

11. Map showing simulated hydraulic conductivity of the Jasper aquifer in the Houston Area Groundwater Model study area

12. Map showing simulated sand storativity of the Chicot aquifer in the Houston Area Groundwater Model study area

13. Map showing simulated sand storativity of the Evangeline aquifer in the Houston Area Groundwater Model study area

14. Map showing simulated sand storativity of the Jasper aquifer in the Houston Area Groundwater Model study area

15. Map showing simulated inelastic-clay storativity of the Chicot aquifer in the Houston Area Groundwater Model study area

16. Map showing simulated inelastic-clay storativity of the Evangeline aquifer in the Houston Area Groundwater Model study area

17. Map showing simulated inelastic-clay storativity of the Burkeville confining unit in the Houston Area Groundwater Model study area

18. Map showing simulated inelastic-clay storativity of the Jasper aquifer in the Houston Area Groundwater Model study area

19. Map showing simulated and measured potentiometric surfaces of the Chicot aquifer, 2009, and location of monitoring wells in the Houston Area Groundwater Model study area

20. Map showing simulated and measured potentiometric surfaces of the Evangeline aquifer, 2009, and location of monitoring wells in the Houston Area Groundwater Model study area

21. Map showing simulated and measured potentiometric surfaces of the Jasper aquifer, 2009, and location of monitoring wells in the Houston Area Groundwater Model study area

22. Graph showing relation between simulated and measured heads for the Chicot, Evangeline, and Jasper aquifers, 2009, in the Houston Area Groundwater Model study area

23. Map showing spatial distribution of water-level (head) residuals (measured minus simulated heads) for the Chicot aquifer, 2009, in the Houston Area Groundwater Model study area

24. Map showing spatial distribution of water-level (head) residuals (measured minus simulated heads) for the Evangeline aquifer, 2009, in the Houston Area Groundwater Model study area 
25. Map showing spatial distribution of water-level (head) residuals (measured minus simulated heads) for the Jasper aquifer, 2009, in the Houston Area Groundwater Model study area

26. Graph showing hydrographs showing simulated and measured water levels in selected observation wells screened in the Chicot aquifer in $A$, Brazoria, $B$, Galveston, $C$, Harris, and $D$, Fort Bend Counties in the Houston Area Groundwater Model study area

27. Graph showing hydrographs showing simulated and measured water levels in selected observation wells screened in the Evangeline aquifer in $A$, Brazoria, $B$, Fort Bend, and $C, D$, Harris Counties in the Houston Area Groundwater Model study area

28. Graph showing hydrographs showing simulated and measured water levels in selected observation wells screened in the Jasper aquifer in $A, B, C$, Harris and $D$, Montgomery Counties in the Houston Area Groundwater Model study area

29. Simulated 2009 water-budget components of the hydrogeologic units of the Houston Area Groundwater Model

30. Map showing simulated (1891-2000) and measured (1906-2000) land-surface subsidence in the Houston Area Groundwater Model study area

31. Map showing simulated (1891-2009) and measured (1906-2000) land-surface subsidence in the Houston Area Groundwater Model study area

32. Map showing predictions Relating Effective Stress to Subsidence (PRESS) model site locations and PRESS simulated land-surface subsidence, 1906-2000, and Houston Area Groundwater Model simulated land-surface subsidence (1891-2009) and measured land-surface subsidence (1906-2000) in the Houston Area Groundwater Model study area

33. Graph showing sensitivity of simulated water levels to changes in selected calibrated model input data of the Houston Area Groundwater Model

34. Graph showing sensitivity of simulated land-surface subsidence to changes in selected calibrated model input data of the Houston Area Groundwater Model

\section{Tables}

1. Groundwater withdrawal (stress) periods used in the Houston Area Groundwater Model

2. Comparison of calibrated-parameter values used in the Groundwater Availability Model (2004) and the Houston Area Groundwater Model

3. Number of water-level (head) measurements, root-mean-square errors of simulated head, and range of total simulated head in the Chicot, Evangeline, and Jasper aquifers, 2009

4. Volumetric budget for the Houston Area Groundwater Model at the end of stress period 78, 2009 


\section{Conversion Factors and Datums}

\section{Inch/Pound to SI}

\begin{tabular}{|c|c|c|}
\hline Multiply & By & To obtain \\
\hline \multicolumn{3}{|c|}{ Length } \\
\hline inch (in.) & 2.54 & centimeter $(\mathrm{cm})$ \\
\hline inch (in.) & 25.4 & millimeter (mm) \\
\hline foot $(\mathrm{ft})$ & 0.3048 & meter $(\mathrm{m})$ \\
\hline mile (mi) & 1.609 & kilometer (km) \\
\hline square mile $\left(\mathrm{mi}^{2}\right)$ & 259.0 & hectare (ha) \\
\hline square mile $\left(\mathrm{mi}^{2}\right)$ & 2.590 & square kilometer $\left(\mathrm{km}^{2}\right)$ \\
\hline \multicolumn{3}{|c|}{ Volume } \\
\hline gallon (gal) & 3.785 & liter (L) \\
\hline gallon (gal) & 0.003785 & cubic meter $\left(\mathrm{m}^{3}\right)$ \\
\hline million gallons (Mgal) & 3,785 & cubic meter $\left(\mathrm{m}^{3}\right)$ \\
\hline cubic foot $\left(\mathrm{ft}^{3}\right)$ & 0.02832 & cubic meter $\left(\mathrm{m}^{3}\right)$ \\
\hline cubic foot per second $\left(\mathrm{ft}^{3} / \mathrm{s}\right)$ & 0.02832 & cubic meter per second $\left(\mathrm{m}^{3} / \mathrm{s}\right)$ \\
\hline cubic foot per day $\left(\mathrm{ft}^{3} / \mathrm{d}\right)$ & 0.02832 & cubic meter per day $\left(\mathrm{m}^{3} / \mathrm{d}\right)$ \\
\hline million gallons per day (Mgal/d) & 0.04381 & cubic meter per second $\left(\mathrm{m}^{3} / \mathrm{s}\right)$ \\
\hline \multicolumn{3}{|c|}{ Flow rate } \\
\hline gallon per minute (gal/min) & 0.06309 & liter per second $(\mathrm{L} / \mathrm{s})$ \\
\hline \multicolumn{3}{|c|}{ Mass } \\
\hline pound, avoirdupois (lb) & 0.4536 & kilogram (kg) \\
\hline \multicolumn{3}{|c|}{ Pressure } \\
\hline pound per square foot $\left(\mathrm{lb} / \mathrm{ft}^{2}\right)$ & 0.04788 & kilopascal $(\mathrm{kPa})$ \\
\hline \multicolumn{3}{|c|}{ Density } \\
\hline pound per cubic foot $\left(\mathrm{lb} / \mathrm{ft}^{3}\right)$ & 16.02 & kilogram per cubic meter $\left(\mathrm{kg} / \mathrm{m}^{3}\right)$ \\
\hline pound per cubic foot $\left(\mathrm{lb} / \mathrm{ft}^{3}\right)$ & 0.01602 & gram per cubic centimeter $\left(\mathrm{g} / \mathrm{cm}^{3}\right)$ \\
\hline \multicolumn{3}{|c|}{ Hydraulic conductivity } \\
\hline foot per day (ft/d) & 0.3048 & meter per day $(\mathrm{m} / \mathrm{d})$ \\
\hline \multicolumn{3}{|c|}{ Hydraulic gradient } \\
\hline foot per mile (ft/mi) & 0.1894 & meter per kilometer $(\mathrm{m} / \mathrm{km})$ \\
\hline \multicolumn{3}{|c|}{ Transmissivity* } \\
\hline foot squared per day $\left(\mathrm{ft}^{2} / \mathrm{d}\right)$ & 0.09290 & meter squared per day $\left(\mathrm{m}^{2} / \mathrm{d}\right)$ \\
\hline
\end{tabular}




\section{SI to Inch/Pound}

\begin{tabular}{|c|c|c|}
\hline Multiply & By & To obtain \\
\hline \multicolumn{3}{|c|}{ Volume } \\
\hline liter (L) & 33.82 & ounce, fluid (fl. oz) \\
\hline liter $(\mathrm{L})$ & 2.113 & $\operatorname{pint}(\mathrm{pt})$ \\
\hline liter (L) & 1.057 & quart (qt) \\
\hline liter (L) & 0.2642 & gallon (gal) \\
\hline \multicolumn{3}{|c|}{ Mass } \\
\hline gram (g) & 0.03527 & ounce, avoirdupois (oz) \\
\hline
\end{tabular}

Temperature in degrees Fahrenheit $\left({ }^{\circ} \mathrm{F}\right)$ may be converted to degrees Celsius $\left({ }^{\circ} \mathrm{C}\right)$ as follows:

$$
{ }^{\circ} \mathrm{C}=\left({ }^{\circ} \mathrm{F}-32\right) / 1.8
$$

Vertical coordinate information is referenced to the North American Vertical Datum of 1988 (NAVD 88).

Horizontal coordinate information is referenced to the North American Datum of 1983 (NAD 83).

Altitude, as used in this report, refers to distance above or below the vertical datum.

*Transmissivity: The standard unit for transmissivity is cubic foot per day per square foot times foot of aquifer thickness [( $\left.\left.\mathrm{ft}^{3} / \mathrm{d}\right) / \mathrm{ft}^{2}\right] \mathrm{ft}$. In this report, the mathematically reduced form, foot squared per day $\left(\mathrm{ft}^{2} / \mathrm{d}\right)$, is used for convenience.

Concentrations of chemical constituents in water are given either in milligrams per liter (mg/L) or micrograms per liter ( $\mu \mathrm{g} / \mathrm{L})$. 



\title{
Hydrogeology and Simulation of Groundwater Flow and Land-Surface Subsidence in the Northern Part of the Gulf Coast Aquifer System, Texas, 1891-2009
}

\author{
By Mark C. Kasmarek
}

\begin{abstract}
In cooperation with the Harris-Galveston Subsidence District, Fort Bend Subsidence District, and Lone Star Groundwater Conservation District, the U.S. Geological Survey developed and calibrated the Houston Area Groundwater Model (HAGM), which simulates groundwater flow and land-surface subsidence in the northern part of the Gulf Coast aquifer system in Texas from predevelopment (before 1891) through 2009. Withdrawal of groundwater since development of the aquifer system has resulted in potentiometric surface (hydraulic head, or head) declines in the Gulf Coast aquifer system and land-surface subsidence (primarily in the Houston area) from depressurization and compaction of clay layers interbedded in the aquifer sediments.
\end{abstract}

The MODFLOW-2000 groundwater flow model described in this report comprises four layers, one for each of the hydrogeologic units of the aquifer system except the Catahoula confining system, the assumed no-flow base of the system. The HAGM is composed of 137 rows and 245 columns of 1-square-mile grid cells with lateral no-flow boundaries at the extent of each hydrogeologic unit to the northwest, at groundwater divides associated with large rivers to the southwest and northeast, and at the downdip limit of freshwater to the southeast. The model was calibrated within the specified criteria by using trial-and-error adjustment of selected model-input data in a series of transient simulations until the model output (potentiometric surfaces, land-surface subsidence, and selected water-budget components) acceptably reproduced field measured (or estimated) aquifer responses including water level and subsidence. The HAGM-simulated subsidence generally compared well to 26 Predictions Relating Effective Stress to Subsidence (PRESS) models in Harris, Galveston, and Fort Bend Counties. Simulated HAGM results indicate that as much as 10 feet (ft) of subsidence has occurred in southeastern Harris County. Measured subsidence and model results indicate that a larger geographic area encompassing this area of maximum subsidence and much of central to southeastern Harris County has subsided at least $6 \mathrm{ft}$. For the western part of the study area, the HAGM simulated as much as $3 \mathrm{ft}$ of subsidence in Wharton, Jackson, and Matagorda Counties. For the eastern part of the study area, the HAGM simulated as much as $3 \mathrm{ft}$ of subsidence at the boundary of Hardin and Jasper Counties. Additionally, in the southeastern part of the study area in Orange County, the HAGM simulated as much as $3 \mathrm{ft}$ of subsidence. Measured subsidence for these areas in the western and eastern parts of the HAGM has not been documented.

\section{Introduction}

The availability of groundwater for municipal, industrial, and agricultural uses, as well as the potential subsidence associated with groundwater use, has been of concern in the Houston, Texas, area for decades (Lang and Winslow, 1950; Doyel and Winslow, 1954; Wood, 1956; Wood and others, 1963; Wood and Gabrysch, 1965; Jorgenson, 1975; Gabrysch and Bonnett, 1975; Gabrysch, 1982). In 2004, in cooperation with Texas Water Development Board and Harris-Galveston Coastal Subsidence District (now known as the HarrisGalveston Subsidence District), the U.S. Geological Survey (USGS) developed a groundwater flow model referred to as the "Northern Gulf Coast Groundwater Availability Model" (GAM) (Kasmarek and Robinson, 2004), which simulated the potentiometric surface (hydraulic head, or head) and clay compaction in the main water-bearing units of the Gulf Coast aquifer system from 1891 to 2000. Because areal distribution of groundwater withdrawals has changed in the study area (and subsequently, areas undergoing land-surface subsidence as a result) since 2000, a need was identified by water managers in the greater Houston area to update the GAM (Kasmarek and Robinson, 2004) to more accurately reflect recent (2009) conditions. Accordingly, the USGS, in cooperation with the Harris-Galveston Subsidence District (HGSD), the Fort Bend Subsidence District (FBSD), and the Lone Star Groundwater Conservation District (LSGCD), prepared a groundwater model of the Houston area, referred to hereinafter as the Houston Area Groundwater Model (HAGM). The objective of the HAGM is to accurately simulate and provide reliable, timely data on groundwater 
availability and land-surface subsidence in the Houston area through 2009. Local and regional water managers can use the HAGM as a tool to simulate aquifer response (changes in water levels and clay compaction) to future estimated water demands. The previous model (GAM) simulated groundwater flow in the Chicot and Evangeline aquifers and in parts of the Burkeville confining unit and Jasper aquifer that contain freshwater (Kasmarek and Robinson, 2004, figs. 20 and 21) and simulated land-surface subsidence in the Chicot and Evangeline aquifers. Like the GAM, the HAGM simulates groundwater flow in the Chicot and Evangeline aquifers and parts of the Jasper aquifer and Burkeville confining unit, but unlike the GAM the HAGM also simulates subsidence in the Jasper aquifer and the Burkeville confining unit.

\section{Purpose and Scope}

The purpose of this report is to describe the hydrogeology and simulation of groundwater flow and landsurface subsidence in the northern part of the Gulf Coast aquifer system in the HAGM study area (fig. 1). Additionally, this report documents changes made to the previous model (GAM), the parent model of the HAGM. For this report, "predevelopment" refers to conditions prior to 1891, and "postdevelopment" refers to 1891-2009. The hydrogeologic units, hydraulic properties, flow conditions, and development (groundwater withdrawals) of the HAGM are based on available information and have been modified from the original GAM as necessary. The hydrogeologic units from land surface downward are the Chicot aquifer, Evangeline aquifer, Burkeville confining unit, Jasper aquifer, and Catahoula confining system. Little mention of the Catahoula confining system is included because it was not simulated in the model. Groundwater flow was simulated for parts of the hydrogeologic units that contain freshwater.

\section{Previous Studies}

The Gulf Coast aquifer system in the Houston region has been extensively studied. Nine previous groundwater-flowmodeling studies, including two that simulated land-surface subsidence, have been completed in all or parts of the HAGM study area. From the earliest to most recent, the models were authored by Wood and Gabrysch (1965); Jorgensen (1975); Meyer and Carr (1979); Trescott (1975); Espey, Huston and Associates, Inc. (1982); Carr and others (1985); LBGGuyton Associates (1997); Kasmarek and Strom (2002); and Kasmarek and Robinson (2004). LBG-Guyton Associates (1997) were the first to use the USGS groundwater-flow model MODFLOW to simulate water levels (heads) in the Houston area (McDonald and Harbaugh, 1988; Harbaugh and McDonald, 1996).

The first model to simulate land-surface subsidence is known as the Predictions Relating Effective Stress to Subsidence (PRESS) model, which uses a modified version of the compaction (COMPAC) code developed by Helm $(1975 ; 1976 a, b ; 1978)$. A model of land-surface subsidence (Fugro-McClelland [Southwest], Inc., 1997) was designed to be used with, but was not part of, the LBG-Guyton Associates (1997) groundwater-flow model. Similar to the model by Espey, Huston and Associates, Inc. (1982), the model by Fugro-McClelland (Southwest), Inc. (1997), used the PRESS code to simulate land-surface subsidence. The simulated water-level declines from the LBG-Guyton Associates (1997) groundwater-flow model were used as input data for PRESS models at 22 separate sites in the Houston area. Kasmarek and Strom (2002) and Kasmarek and Robinson (2004) used MODFLOW (Harbaugh and McDonald, 1996) to simulate groundwater flow in the Chicot and Evangeline aquifers of the Houston-Galveston region and the northern part of the Gulf Coast aquifer system, respectively, and the InterbedStorage (IBS) package (Leake and Prudic, 1991) was used to simulate clay compaction and storage in the aquifers. Additional summary information about the previous models described in this section is presented in Kasmarek and Robinson (2004).

\section{Description of Study Area for the Houston Area Groundwater Model}

The HAGM study area (fig. 1) includes all or parts of 38 counties in southeastern Texas. The HAGM area is a gently sloping coastal plain, and land-surface elevations are topographically highest along the northwestern boundary. The vegetation in the northern parts of the HAGM area generally is composed of hardwood and pine forests, but as land-surface altitude decreases toward the coast, the vegetation becomes increasingly dominated by shrubs and grasses. Numerous constructed lakes and reservoirs are in the HAGM area, but those surficial water bodies generally only influence the water table on a local scale. The Gulf of Mexico and Galveston Bay have a large effect on the downdip groundwater-flow system and climate of the area. Winters in the HAGM area are mild with few days of freezing temperatures. During winter, moisture-laden Pacific and Canadian air masses produce regionally extensive bands of moderate rainfall. Summers are hot with high relative humidity, and prevailing winds are from the south to southwest (Kasmarek and Robinson, 2004). During summer, atmospheric convective cells can produce rates of precipitation from light to extreme ( 0.01 inches [in.] per hour to 2.0 in. per hour or more) (Federal Aviation Agency, 2007). Infrequently, moisture-laden tropical air masses produce light to extreme rates of precipitation with a reported rate of $38.8 \mathrm{in}$. being recorded from June 5 to June 9, 2001, related to Tropical Storm Allison (National Oceanic and Atmospheric Administration, 2012a). The average annual rainfall for the greater Houston area is 47.84 in., and the average annual temperature is about 68.8 degrees Fahrenheit (National Oceanic and Atmospheric Administration, 2012). 


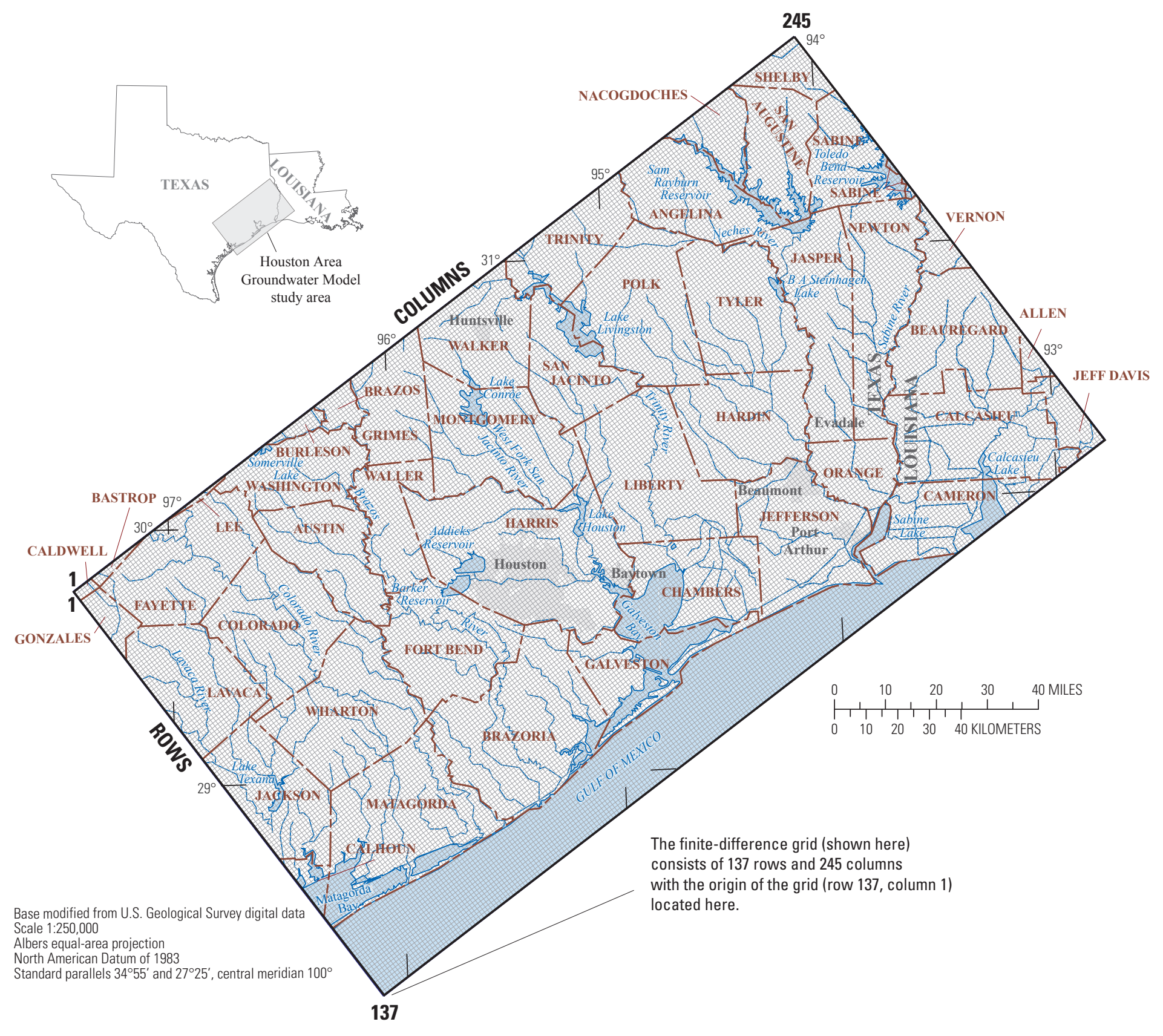

Figure 1. Location of the Houston Area Groundwater Model study area and finite-difference grid, southeastern Texas and southwestern Louisiana. 


\section{Hydrogeology}

In a generalized conceptual model of the Gulf Coast aquifer system, the fraction of precipitation that does not evaporate, transpire through plants, or run off the land surface to streams enters the groundwater-flow system in topographically high updip outcrop areas of the hydrogeologic units in the northwestern part of the system. Most precipitation infiltrating into the saturated zone flows relatively short distances through shallow zones and then discharges to streams. The remainder of the water flows to intermediate and deep zones of the system southeastward of the outcrop areas where it is discharged by wells (in the developed system) and by upward leakage in topographically low areas near or along the coast (in both predevelopment and postdevelopment, but appreciably less in postdevelopment). Near the coast and at depth, saline water is present. The saline water causes lessdense freshwater that has not been captured and discharged by wells to be redirected upward as diffuse leakage to shallow zones of the aquifer system and ultimately to be discharged to coastal water bodies. Because groundwater flow was simulated in the HAGM only as far as the downdip limit of freshwater, only the parts of the hydrogeologic units containing freshwater are described in this report (Kasmarek and Robinson, 2004).

\section{Hydrogeologic Units and Geologic Setting}

The thicknesses of the four stratigraphic units used in the HAGM coincide with the GAM of Kasmarek and Robinson (2004) and originated from Strom and others (2003c). From land surface downward, the Chicot aquifer, the Evangeline aquifer, the Burkeville confining unit, the Jasper aquifer, and the Catahoula confining system are the hydrogeologic units of the Gulf Coast aquifer system (fig. 2), as described by Baker (1979, 1986) and by Ashworth and Hopkins (1995). In general, where the hydrogeologic units crop out, they do so parallel to the coast and thicken downdip to the southeast with the older units having a greater dip angle (fig. 2). The correlation of hydrogeologic units with stratigraphic units is shown in figure 3. The Chicot aquifer comprises (youngest to oldest) the alluvium, Beaumont Formation, Montgomery Formation, Bentley Formation, and Willis Formation. The Evangeline aquifer comprises (youngest to oldest) the Goliad Sand and the upper part of the Fleming Formation. The Burkeville confining unit consists entirely of the Fleming Formation. The Jasper aquifer comprises (youngest to oldest) the lower part of the Fleming Formation throughout its subsurface extent and the upper part of the Catahoula Sandstone in its outcrop and updip parts (fig. 3). The basal unit for this report is the Catahoula confining system, which comprises the Catahoula Sandstone and, downdip, the Anahuac and Frio Formations (Kasmarek and Robinson, 2004).

The updip limit of the Chicot aquifer is an undulating boundary approximately parallel to the coast and extending as far north as Lavaca, Colorado, Austin, Waller, Grimes, Montgomery, San Jacinto, Polk, Tyler, Jasper, and Newton Counties (fig. 4). To the southeast, the freshwater part of the aquifer extends beneath the Gulf of Mexico. The altitude of the top of the Chicot aquifer in the HAGM study area approximates the land-surface altitude and ranges from the North American Vertical Datum of 1988 (NAVD 88, hereinafter, datum) at the coast to as much as 445 feet (ft) above datum at its updip limit (Kasmarek and Robinson, 2004, fig. 9). The altitude of the base of the Chicot aquifer in the HAGM study area (Kasmarek and Robinson, 2004, fig. 10) ranges from more than $1,500 \mathrm{ft}$ below Datum southeast of the coast to more than $420 \mathrm{ft}$ above Datum in the outcrop area and varies locally because of numerous salt domes in the study area (Kasmarek and Robinson, 2004, fig. 27). The altitude of the base of the Chicot aquifer was constructed from hydrogeologic digital data of Strom and others (2003a). The original cumulative clay thickness of the Chicot aquifer (Kasmarek and Robinson, 2004, fig. 12) was subtracted from aquifer thickness to construct cumulative sand thickness (Kasmarek and Robinson, 2004, fig. 13).

The updip limit of the Evangeline aquifer is an undulating boundary approximately parallel to the coast and extending as far north as Lavaca, Fayette, Austin, Washington, Grimes, Montgomery, Walker, San Jacinto, Polk, Tyler, Jasper, and Newton Counties (fig. 5). The downdip limit of freshwater is approximately coincident with the coast. The altitude of the top of the Evangeline aquifer in the HAGM study area ranges from more than 1,440 ft below datum to as much as $469 \mathrm{ft}$ above datum at its updip limit (Kasmarek and Robinson, 2004, fig. 15). The altitude of the base of the Evangeline aquifer in the HAGM study area (Kasmarek and Robinson, 2004, fig. 16) ranges from more than $5,300 \mathrm{ft}$ below datum at the coast to $430 \mathrm{ft}$ above datum in the outcrop area and varies locally because of numerous salt domes (Kasmarek and Robinson, 2004, fig. 27). The base of the Evangeline aquifer transgresses the stratigraphic boundary between the Goliad Sand and the Fleming Formation. (This transgression is not shown in the section depicted in figure 2 , as only outcropping stratigraphic units are shown.) The altitude of the base of the Evangeline aquifer is presented in Strom and others (2003b). The original cumulative clay thickness of the Evangeline aquifer (Kasmarek and Robinson, 2004, fig. 18) is from Gabrysch (1982, fig. 37) and was subtracted from aquifer thickness to construct cumulative sand thickness (Kasmarek and Robinson, 2004, fig. 19).

The updip limit of the Burkeville confining unit is an undulating boundary approximately parallel to the coast and extending as far north as Lavaca, Fayette, Austin, Washington, Grimes, Montgomery, Walker, San Jacinto, Polk, Tyler, Jasper, and Newton Counties (fig. 6). The Burkeville confining unit lies stratigraphically below the Evangeline aquifer and above the Jasper aquifer (fig. 2) and restricts flow between the Evangeline and Jasper aquifers because of its relatively large percentage of silt and clay compared to the percentages of the adjacent aquifers (Baker, 1979). Southeast of the 


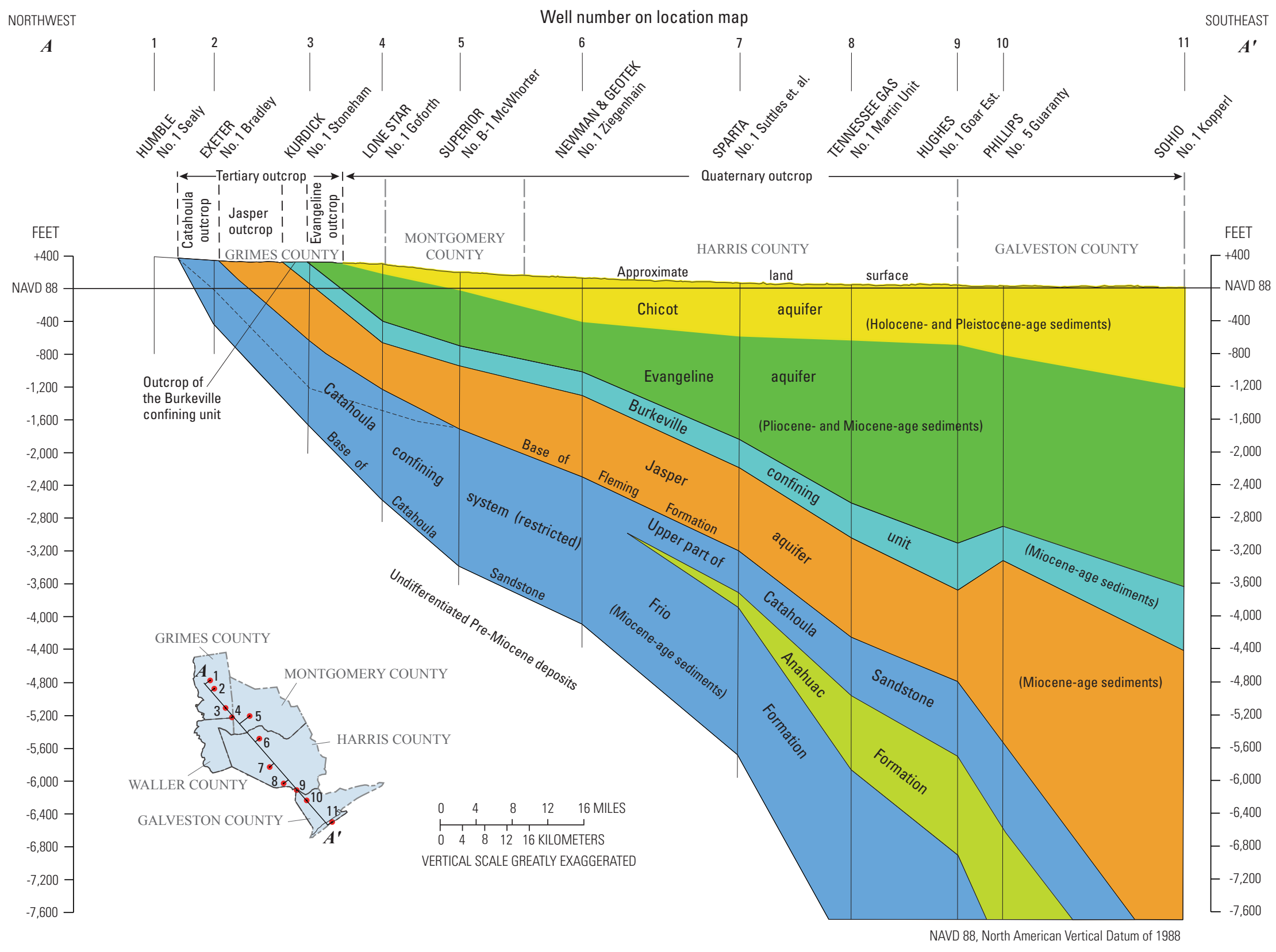

Figure 2. Hydrogeologic section of the Gulf Coast aquifer system in Harris County and adjacent counties, Texas. 


\begin{tabular}{|c|c|c|c|c|}
\hline \multicolumn{3}{|c|}{ Geologic (stratigraphic) units } & \multirow{2}{*}{$\begin{array}{c}\text { Hydrogeologic } \\
\text { units }\end{array}$} & \multirow{2}{*}{$\begin{array}{l}\text { Model } \\
\text { layer }\end{array}$} \\
\hline System & Series & Formation & & \\
\hline \multirow{5}{*}{ Quaternary } & Holocene & Alluvium & \multirow{5}{*}{$\begin{array}{l}\text { Chicot } \\
\text { aquifer }\end{array}$} & \multirow{5}{*}{1} \\
\hline & \multirow{4}{*}{ Pleistocene } & $\begin{array}{l}\text { Beaumont } \\
\text { Formation }\end{array}$ & & \\
\hline & & $\begin{array}{l}\text { Montgomery } \\
\text { Formation }\end{array}$ & & \\
\hline & & $\begin{array}{c}\text { Bentley } \\
\text { Formation }\end{array}$ & & \\
\hline & & Willis Formation & & \\
\hline \multirow{6}{*}{ Tertiary } & Pliocene & Goliad Sand & Evangeline & 2 \\
\hline & \multirow{5}{*}{ Miocene } & $\begin{array}{l}\text { Fleming } \\
\text { Formation }\end{array}$ & $\begin{array}{c}\text { Burkeville } \\
\text { confining } \\
\text { unit }\end{array}$ & 3 \\
\hline & & \begin{tabular}{|c|c} 
Oakville \\
Sandstone
\end{tabular} & $\begin{array}{l}\text { Jasper } \\
\text { Jaifer }\end{array}$ & \multirow{4}{*}{4} \\
\hline & & $\begin{array}{l}\text { Catahoula } \\
\text { Sandstone }\end{array}$ & & \\
\hline & & $\begin{array}{l}\text { Anahuac } \\
\text { Formation }\end{array}$ & & \\
\hline & & KFrio & $\begin{array}{l}\text { confining } \\
\text { system }\end{array}$ & \\
\hline
\end{tabular}

${ }^{1}$ Present only in subsurface.

Figure 3. Correlation of stratigraphic and hydrogeologic units in the Houston Area Groundwater Model study area.

downdip limit of freshwater (fig. 6), this unit is considered (for HAGM simulation purposes) a no-flow unit that prevents diffuse upward leakage of saline water from the Jasper aquifer. In updip areas of the Burkeville confining unit (fig. 6), the sediments are slightly more transmissive and thus able to supply small quantities of water for domestic use. In the outcrop area, the altitude of the top of the Burkeville confining unit is equal to the land-surface altitude, and in the subcrop area, the top of the Burkeville confining unit is coincident with the base of the Evangeline aquifer. The altitude of the base of the Burkeville confining unit is coincident with the top of the Jasper aquifer and varies locally because of the numerous salt domes in the area (Kasmarek and Robinson, 2004, fig. 27).

The updip limit of the Jasper aquifer is an undulating boundary approximately parallel to the coast and extending as far north as Lavaca, Gonzales, Fayette, Washington, 


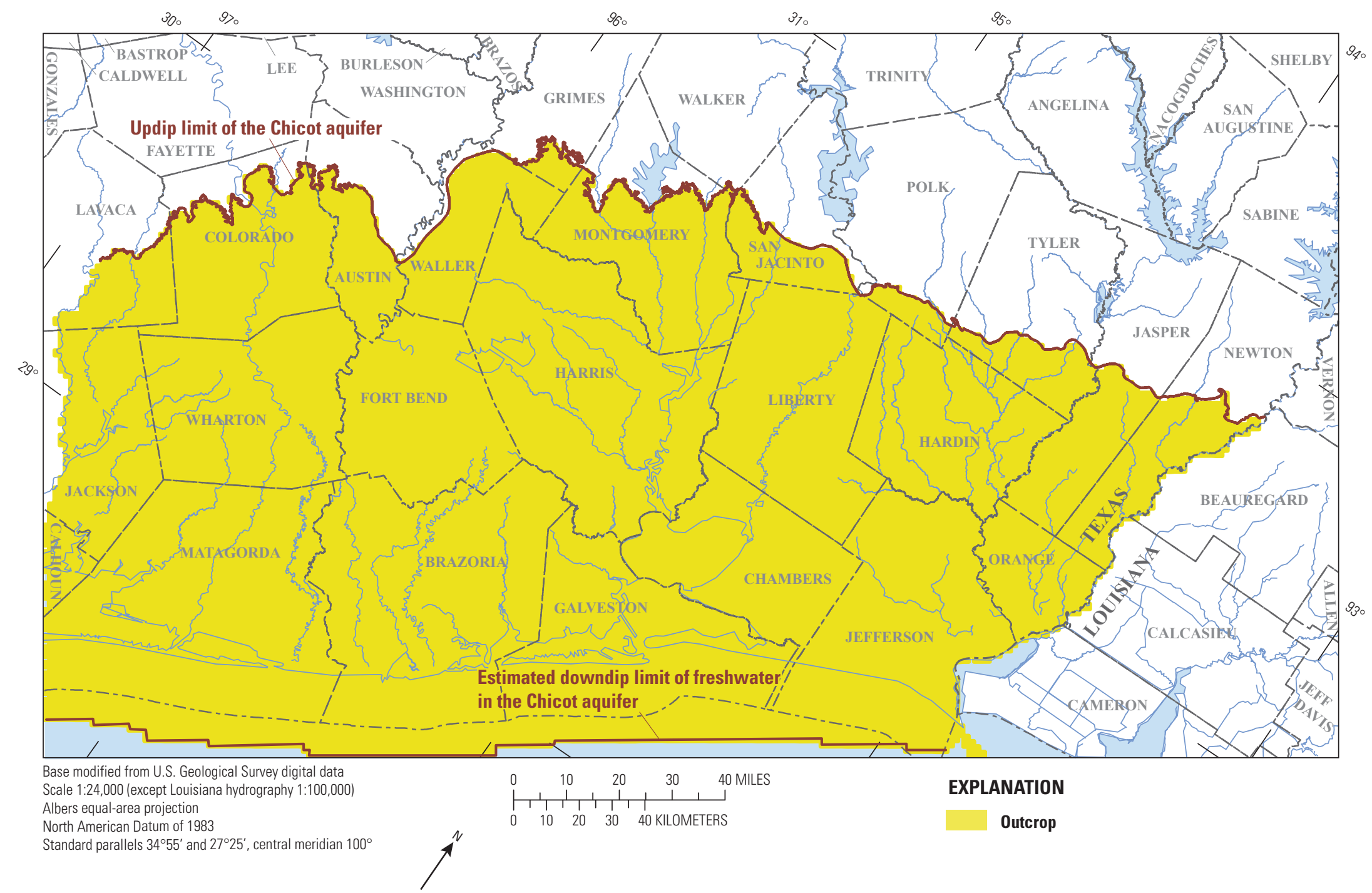




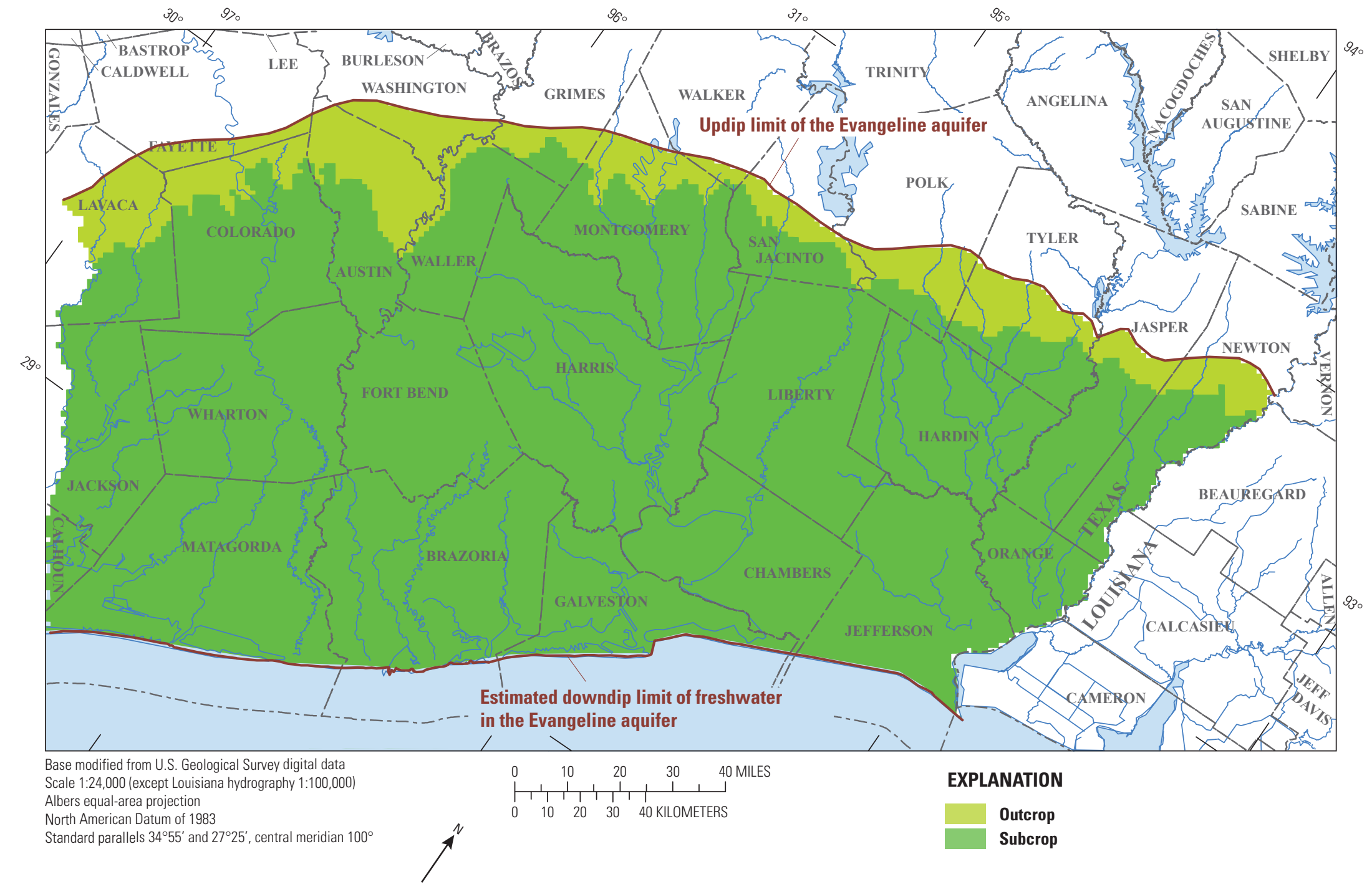

Figure 5. Extent, outcrop area, and subcrop area of the Evangeline aquifer in the Houston Area Groundwater Model study area. 


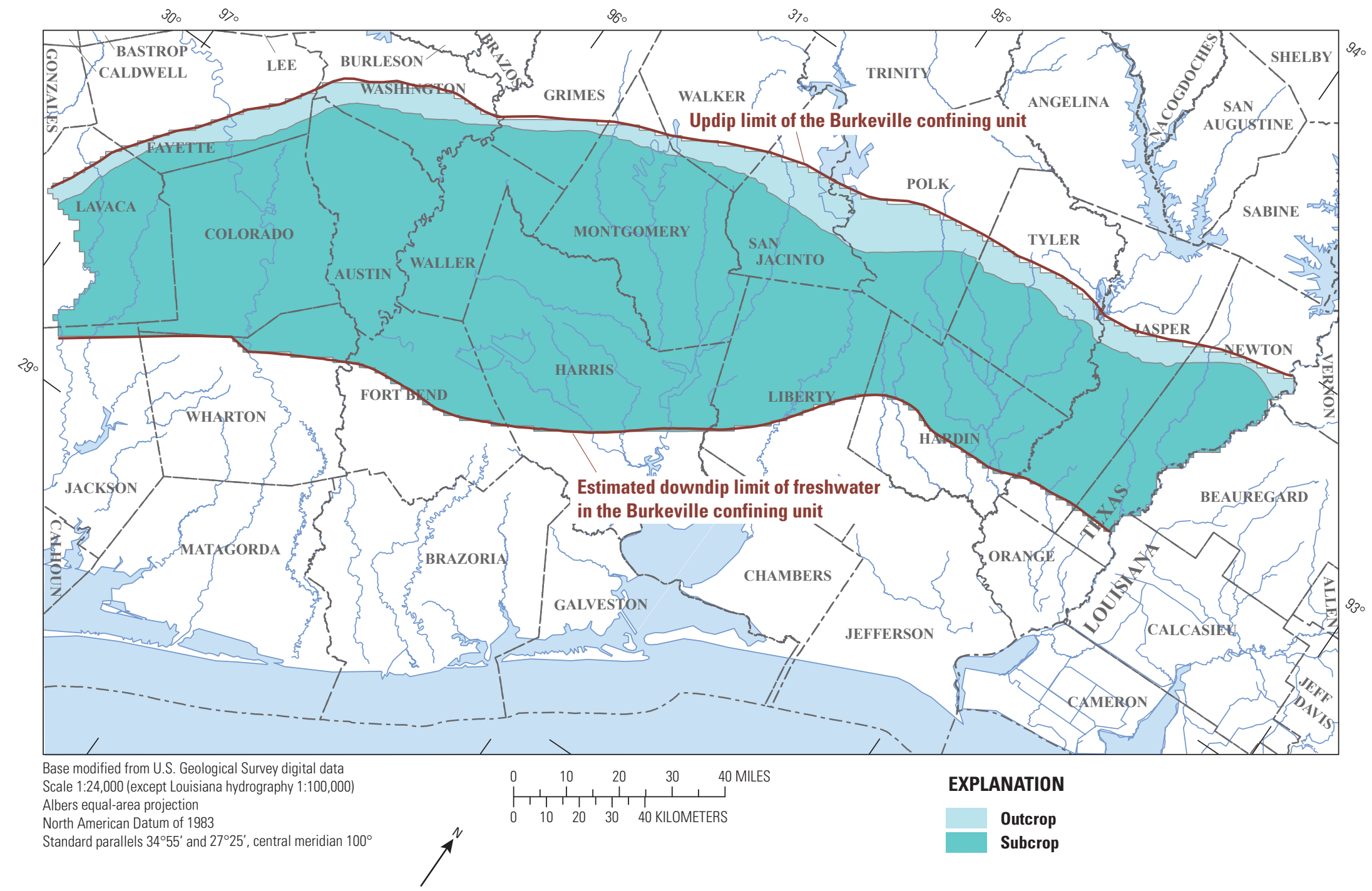


Brazos, Grimes, Walker, Trinity, Polk, Tyler, Angelina, Jasper, Newton, and Sabine Counties (fig. 7). Southeast of the downdip limit of freshwater, this unit is considered (for HAGM simulation purposes) a no-flow unit that prevents diffuse upward leakage of saline water. The altitude of the top of the Jasper aquifer in the HAGM study area ranges from less than 2,800 ft below datum to about $900 \mathrm{ft}$ above datum at its updip limit (Kasmarek and Robinson, 2004, fig. 22). The altitude of the base of the freshwater part of the Jasper aquifer (Kasmarek and Robinson, 2004, fig. 23) ranges from about $3,800 \mathrm{ft}$ below datum near the downdip limit of freshwater to about $500 \mathrm{ft}$ above datum in the outcrop area and varies locally because of numerous salt domes (Kasmarek and Robinson, 2004, fig. 27). The base of the Jasper aquifer in updip areas transgresses the stratigraphic boundary between the Fleming Formation and the Catahoula Sandstone (figs. 2 and 3). Strom and others (2003c) estimated the altitudes of the top and base of the Jasper aquifer and evaluated the thickness of the aquifer (Kasmarek and Robinson, 2004, fig. 24). The original cumulative clay thickness of the Jasper aquifer (Kasmarek and Robinson, 2004, fig. 25) was subtracted from aquifer thickness to construct the cumulative sand thickness (Kasmarek and Robinson, 2004, fig. 26). The basal unit for the HAGM (fig. 2) is the Catahoula confining system, which comprises the Catahoula Sandstone and, downdip, the Anahuac and Frio Formations. The Jasper aquifer is underlain by the Catahoula confining system, which is composed mostly of clay or tuff. The Catahoula confining system impedes substantial exchange of water between the Jasper aquifer and underlying units (Baker, 1986).

The paleodepositional environment of the sediments that formed the Gulf Coast aquifer system was a fluvial-deltaic or shallow-marine environment that produced interlayered, discontinuous sequences of clay, silt, sand, and gravel (Kasmarek and Robinson, 2004). (In this report, the term "sand" refers to coarse-grained sand and gravel sediments, whereas "clay" refers to fine-grained sediments including clay and silt.) Changes in land-surface altitudes related to naturally occurring land-surface subsidence of the depositional basin and sea-level transgressions and regressions created cyclical sedimentation facies. During periods when the sea level declined, fluvial deltaic processes deposited continental sediments, but as the sea level rose, the deposited continental sediments were reworked, and marine sediments were deposited. Because of this complex depositional process, the facies alternate cyclically from the predominantly continental sediments that compose the aquifers to the predominantly marine sediments that compose the confining units and clay layers within aquifers; therefore, the Gulf Coast aquifer system has a high degree of heterogeneity in both lateral and vertical extents (Sellards and others, 1932).

Normal growth faults are common throughout the unconsolidated sediments of the HAGM study area, and traces of some of these faults have been mapped and named. Based on the study of well logs and seismic-line data, these faults have been delineated to depths of 3,000-12,000 ft below land surface (Verbeek and others, 1979). The presence of most of these faults is associated with natural geologic processes. The scale of fault movement is insufficient to completely offset entire hydrogeologic units; however, if an offset results in the juxtaposition of relatively more permeable sediments against relatively less permeable sediments, the rate and direction of groundwater flow could be affected. Although growth faults are common in the study area, the exact locations and frequency with which associated offsets appreciably affect groundwater flow is unknown. Because the distribution and magnitude of such occurrences in the study area are unknown, accounting for them in the HAGM was not possible. Numerous salt domes originating from the Jurassic-age Louann Salt have risen through the overlying strata (Halbouty, 1967) and have been mapped in the HAGM area (Beckman and Williamson, 1990). In some areas, the salt domes have penetrated the aquifers. The upward intrusions of the salt domes decrease the thickness of the adjacent aquifer sediments and radially alter the prevailing hydraulic characteristics and flow paths in the adjacent aquifer sediments. These widely distributed salt domes increase the heterogeneity of the hydraulic characteristics of the aquifers (Kasmarek and Robinson, 2004).

\section{Hydraulic Properties}

Carr and others (1985) estimated transmissivity and storativity of the Chicot and Evangeline aquifers from simulation and are approximately the same as that used in the HAGM. Estimated transmissivity of the Chicot aquifer ranged from about 3,000 to about 50,000 square feet per day $\left(\mathrm{ft}^{2} / \mathrm{d}\right)$, and storativity ranged from about 0.0004 to 0.1 (dimensionless). Estimated transmissivity of the Evangeline aquifer ranges from about 3,000 to about $15,000 \mathrm{ft}^{2} / \mathrm{d}$, and storativity ranged from about 0.00005 to 0.1 . For both aquifers, the simulations indicated that the larger storativities are in the updip outcrop areas that are under water-table conditions; the smaller storativities are in downdip areas that are under confined conditions. Baker (1986) estimated transmissivity of the Jasper aquifer from simulation for an area coincident with most of the Jasper aquifer in the HAGM area; the transmissivity of the Jasper aquifer simulated in that study ranged from less than 2,500 to about $35,000 \mathrm{ft}^{2} / \mathrm{d}$. Wesselman (1967) estimated transmissivity for all three aquifers and storativity for the Chicot and Evangeline aquifers from aquifer tests in Jasper, Newton, Orange, and Hardin Counties. Transmissivities of the Chicot aquifer ranged from 12,300 to $68,000 \mathrm{ft}^{2} / \mathrm{d}$; the Evangeline aquifer, 2,130 to $14,800 \mathrm{ft}^{2} / \mathrm{d}$; and the Jasper aquifer, 1,070 to $14,000 \mathrm{ft}^{2} / \mathrm{d}$. Wesselman (1967) also estimated storativities of the Evangeline aquifer ranging from 0.00063 to 0.0015 and of the Jasper aquifer ranging from 0.000382 to 0.00119 . Strom and others $(2003 \mathrm{c})$ reported storativities for the Jasper aquifer as large as 0.2. Several other previous studies (for example Jorgensen, 1975) estimated transmissivity in aquifers for parts of counties in the HAGM study area; those estimates generally are within the ranges listed above. 


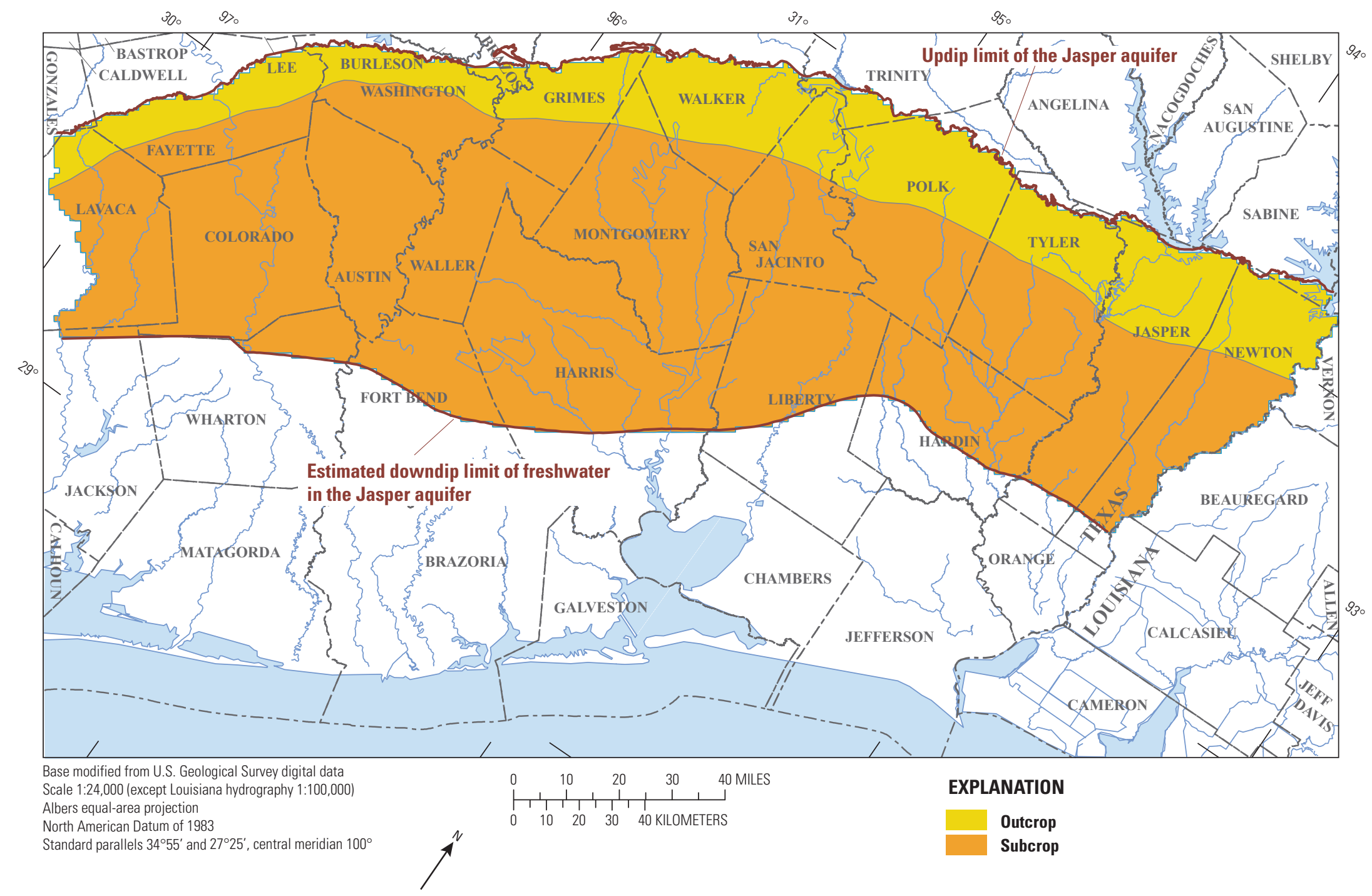


The transmissivity of an aquifer is equal to the hydraulic conductivity multiplied by the thickness of the aquifer (Freeze and Cherry, 1979, p. 59); "hydraulic conductivity" is used extensively in this report. Initial transmissivity distributions for the aquifers were constructed with data from Wesselman (1967), Carr and others (1985), Baker (1986), and Kasmarek and Strom (2002) by using geographic information system (GIS) applications. The initial transmissivity of the Burkeville confining unit was computed by multiplying values of hydraulic conductivity representative of a midrange between silty sand and marine clay (average of 0.01 foot per day [ft/d]) (Freeze and Cherry, 1979, table 2.2, p. 29) by the areally distributed thickness of the confining unit. In this report, hydraulic conductivity refers to horizontal hydraulic conductivity, unless otherwise noted.

\section{Groundwater Flow Conditions, Recharge, and Discharge}

The uppermost parts of the Gulf Coast aquifer system (shallow zones), which include outcrop areas, are under shallow, unconfined water-table conditions. As depth increases in the aquifer system and the cumulative thicknesses of the interbedded sand and clay increase, water-table conditions transition to confined potentiometric conditions. Thus, the lowermost parts of the aquifer system (deep zones) are under confined conditions. The middle parts of the aquifer system (intermediate zones) therefore are under semiconfined conditions. Because the transition from water table to confined conditions incrementally increases with depth, assigning specific depth horizons to shallow, intermediate, and deep zones is problematic (Kasmarek and Robinson, 2004).

Assuming that groundwater flows downgradient and perpendicular to equipotential lines, simulated predevelopment potentiometric surfaces of the Chicot, Evangeline, and Jasper aquifers (Kasmarek and Robinson, 2004, figs. 62-64) confirm the generalized conceptual model of the natural groundwaterflow system. Recharge enters the system in topographically high updip outcrops of the hydrogeologic units in the northwestern parts of the HAGM study area and either flows relatively short distances discharging into topographically lower areas to features such as streams or flows longer distances southeastward through deeper zones, where it is discharged by diffuse-upward leakage in topographically low areas along coastal areas.

As first described by Tóth (1963) and summarized by Johnston (1999) relative to regional aquifer systems, natural (predevelopment) groundwater flow can be subdivided into local, intermediate, and regional flow systems. Local flow follows relatively short flow paths in shallow zones and is controlled mainly by topography. Recharge to local flow systems occurs in topographically high areas, and discharge occurs in nearby, topographically low areas. Intermediate flow moves along relatively deeper flow paths compared to local flow, with groundwater flowing from recharge areas through intermediate zones to downgradient discharge areas. Regional flow follows relatively long flow paths from regional recharge areas through deep zones to distal discharge areas such as the downgradient limits of an aquifer system. Referring to the local, intermediate, and deep flow systems of the aquifer is a basic way to explain the groundwater flow in the aquifer system, but the true nature of the flow system is more complex because of the paleodepositional environment and the stresses of groundwater withdrawals on the aquifer. Tóth (1963) noted that to assume an exact, one-to-one correspondence among local, intermediate, and regional flow systems would be an oversimplification.

If this concept of subdividing natural groundwater flow is applied to the Gulf Coast aquifer system, the implications are that an appreciable amount of the precipitation that infiltrates the subsurface (total recharge) in the relatively topographically high outcrop areas of the hydrogeologic units joins local flow systems. Thus, much of the total precipitation enters from and exits to the shallow subsurface by streams and in topographically low areas. A proportionally smaller amount of the total recharge joins intermediate flow systems, and an even smaller amount of the total recharge joins regional flow systems. Wood (1956, p. 30-33), in an early study of the availability of groundwater in the Gulf Coast region of Texas, stated that, "Within the rainfall belts of 40-50 inches per year, probably 1 inch or more of the water that enters the outcrop of the aquifers updip from the heavily pumped areas is discharged to the streams in the outcrop area as base flow or rejected recharge."

The natural groundwater-flow system has been altered in places (the Houston area, for example) by decades of substantial and concentrated withdrawals in the Chicot and Evangeline aquifers. By 1977, water levels had declined to as much as $250 \mathrm{ft}$ and $350 \mathrm{ft}$ below datum in the Chicot and Evangeline aquifers, respectively (Gabrysch, 1979). Because the Chicot and Evangeline aquifers are hydraulically connected, in these areas, withdrawals have increased verticalhead gradients and have induced downward flow from local and intermediate flow systems into the regional flow system, thus capturing some flow that would have discharged naturally (Gabrysch, 1979).

Few studies that focus specifically on recharge to the system in the HAGM study area are available. For example, Baker (1986) and a study of potential recharge in the Houston area by the U.S. Geological Survey Robert K. Gabrysch [retired] and Fred Liscum [retired], U.S. Geological Survey, written commun., 1995) estimated that the recharge rate across the area ranged from 0.25 in. per year (in./yr) to 7 in./yr. A few additional studies report recharge rates within this range (Tarver, 1968; Sandeen, 1972; Loskot and others, 1982). An in-depth discussion of the results from previous recharge studies in the study area is available in Kasmarek and Robinson (2004). 


\section{Groundwater Development}

Rates of recharge to and discharge from the Chicot, Evangeline, and Jasper aquifers are affected by groundwater withdrawals from those aquifers. "Predevelopment" relative to the HAGM refers to aquifer conditions before 1891 or before the aquifers were measurably stressed by groundwater withdrawals; "postdevelopment" refers to aquifer conditions after the stress of withdrawals became measurable. Initially, the principal areas of concentrated groundwater withdrawals from the aquifer system in the HAGM study area were located in Harris, Galveston, and Fort Bend Counties (the Houston area). Much of the early groundwater-use information for the area, as summarized here, is from Lang and Winslow (1950) and Wood and Gabrysch (1965).

In the area of Houston (founded in 1836), surface water was initially used to meet water-supply demands. In 1886, the first well was drilled to a depth of $140 \mathrm{ft}$ and was reported as free flowing at more than 1,000 gallons per minute (gal/ min) (Lang and Winslow, 1950). By 1906, groundwater withdrawals had the capacity of as much as 19 million gallons per day (Mgal/d). By 1935, withdrawals averaged $24.5 \mathrm{Mgal} / \mathrm{d}$ and by $1941 \mathrm{had}$ increased to $27.2 \mathrm{Mgal} / \mathrm{d}$. From 1941 to 1950, groundwater use more than doubled. In 1954, water released from the newly constructed Lake Houston began to be used to augment groundwater supplies. The additional surface-water supply from Lake Houston resulted in reduced groundwater withdrawals from 1954 to 1960 . From the early 1960s to the mid-1970s, however, groundwater withdrawals increased at rates comparable to pre-1954 rates (Lang and Winslow, 1950). In 1975, because of increasing groundwater withdrawals and subsequent land-surface subsidence in Harris and Galveston Counties, the Harris-Galveston Coastal Subsidence District (HGCSD) was created and began to control land-surface subsidence by regulating groundwater withdrawals. In late 1976, groundwater withdrawals began to decrease in eastern Harris County because part of the demand began to be supplied by water from Lake Livingston. The policies of the newly created HGCSD resulted in decreased groundwater withdrawals in the Baytown and southeastern Harris County areas. The groundwater withdrawal rate exceeded $450 \mathrm{Mgal} / \mathrm{d}$ in 1976 and decreased to about 390 $\mathrm{Mgal} / \mathrm{d}$ in the early $1980 \mathrm{~s}$, but the trend reversed, and by 1990, withdrawals had increased to $493 \mathrm{Mgal} / \mathrm{d}$. A downward trend began again in the 1990s when withdrawals were about $463 \mathrm{Mgal} / \mathrm{d}$ by 1996. By 2000, withdrawals were about 895 Mgal/d (Harris-Galveston Subsidence District, 2012).

\section{Potentiometric Surfaces and Land-Surface Subsidence}

In the updip outcrop area of the Chicot aquifer and the outcrop areas of the Evangeline and Jasper aquifers and Burkeville confining unit (figs. 4-7), water-table conditions generally exist. The water table is assumed to be a subdued replica of the topography (Williams and Williamson, 1989). In outcrops of the Chicot and Evangeline aquifers in parts of Harris and Montgomery Counties, a seismic refraction investigation indicated that the water table ranges from about 10 to $30 \mathrm{ft}$ below land surface (Noble and others, 1996). Hydrographs of water levels in wells screened in the water table of the Chicot and Evangeline aquifers indicate that the water levels were not influenced by increased groundwater withdrawal in the area and have remained fairly stable (Kasmarek and Robinson, 2004, fig. 28). The USGS annually has measured water levels in wells and constructed maps of potentiometric surfaces of the Chicot and Evangeline aquifers in the greater Houston area since 1977 (Gabrysch, 1979) and of the Jasper aquifer since 2000. Related to groundwater withdrawal in the HAGM study area, the 2009 report (Kasmarek, Houston, and Ramage, 2009) in this series indicates that water-level-altitude contours ranged from $250 \mathrm{ft}$ below datum (hereinafter, datum) in a small area in southwestern Harris County to $200 \mathrm{ft}$ above datum in central to southwestern Montgomery County in the Chicot aquifer; from $300 \mathrm{ft}$ below datum in south-central Montgomery County to $200 \mathrm{ft}$ above datum at the intersecting borders of Waller, Montgomery, and Grimes Counties in the Evangeline aquifer; and from $175 \mathrm{ft}$ below datum in south-central Montgomery County to $250 \mathrm{ft}$ above datum in east-central Grimes County in the Jasper aquifer (Kasmarek, Houston, and Ramage, 2009).

In the 1830 s, before groundwater withdrawals from the aquifer system occurred in the HAGM study area, the potentiometric surfaces in the confined parts of the aquifers were higher than land surface. This was demonstrated by a well in Houston that was drilled to $140 \mathrm{ft}$ and flowed at more than $1,000 \mathrm{gal} / \mathrm{min}$. Groundwater development has caused substantial declines of as much as $350 \mathrm{ft}$ below datum (Gabrysch, 1979) of the potentiometric surfaces of the aquifers (and subsequent land-surface subsidence), primarily in Harris, Galveston, and Fort Bend Counties (Kasmarek and Robinson, 2004, figs. 48 and 49). These potentiometric-surface declines in unconsolidated confined aquifers cause a decrease in hydraulic pressure that creates a load on the skeletal matrix of the aquifer (Galloway and others, 1999, p. 9). Because coarsegrained sediments (sand layers) are more transmissive and less compressible than are fine-grained sediments (clay layers), the depressurization of sand layers is relatively rapid compared to that of clay layers and causes only slight skeletal-matrix consolidation. The depressuring and subsequent dewatering of clay layers requires more time compared to that of the sand layers, however, and is dependent on the thickness of the clay layers, the hydraulic characteristics of the clay layers, and the vertical-stress load of the sediment overburden. The delayed drainage of the clay layers continues to occur until the residual excess (transient) pore pressure in the clay layers equals the pore pressure of the adjacent sand layers. Until pressure equilibrium is attained, dewatering of the clay layers continues to apply a load to the skeletal matrix of the clay layers. This loading process is similar to what occurs in the 
sand layers, but additionally, the reorientation of the individual clay grains occurs, becoming perpendicular to the applied vertical load (Galloway and others, 1999, p. 9). Therefore, the dewatering caused by the depressurization of the clay layers combined with clay-grain realignment reduces the porosity and groundwater-storage capacity of the clay layers, which in turn allows them to inelastically and permanently compact. More than $10 \mathrm{ft}$ of land-surface subsidence has been documented in the Baytown area in southwestern Harris County (Gabrysch and Neighbors, 2005; Kasmarek, Gabrysch, and Johnson, 2009). Because of the weight (sediment load) of the overburden and the inelastic compaction characteristics of the clay layers, about 90 percent of the compaction is permanent (Gabrysch and Bonnett, 1975). Thus, when potentiometric surfaces rise and repressure compacted clay layers, there is little, if any, rebound of the land surface (Gabrysch and Bonnett, 1975). Although the compaction of one clay layer generally will not cause a noticeable decrease in the land-surface altitude, if numerous stacked clay-layer sequences (which are characteristic of the Gulf Coast aquifer system) depressure and compact, then appreciable decreases in land-surface altitude can and do occur (Gabrysch and Bonnett, 1975). A substantial amount of the total water withdrawn is derived from dewatering of the numerous clay layers of the aquifer: model simulations indicated that as much as 19 and 10 percent of the total water budget of the Chicot and Evangeline aquifers, respectively, is derived from the dewatering of the clay layers of the aquifers (Kasmarek and Strom, 2002).

\section{Simulation of Groundwater Flow and Land-Surface Subsidence}

\section{Model Description}

The finite-difference computer code MODFLOW-2000 (Harbaugh and others, 2000) was used to create and calibrate the HAGM to simulate groundwater flow and land-surface subsidence in the northern Gulf Coast aquifer system from predevelopment (1891) through 2009. The Subsidence and Aquifer-System Compaction (SUB) package designed for the MODFLOW-2000 model (Hoffman and others, 2003) was used to simulate clay compaction and storage, and thus land-surface subsidence, in the Chicot, Evangeline, and Jasper aquifers and the Burkeville confining unit. The Chicot, Evangeline, and Jasper aquifers and the Burkeville confining unit were simulated as four separate layers and discretized into two-dimensional finite-difference grids (fig. 1). By using GIS applications, model input data were georeferenced and assigned to model grid cells.

\section{Mathematical Representation}

The MODFLOW-2000 model uses finite-difference methods to solve the partial differential equation for threedimensional movement of groundwater of constant density through heterogeneous, anisotropic porous materials. The equation can be written as follows:

$$
\frac{\partial}{\partial x}\left(K x x \frac{\partial h}{\partial x}\right)+\frac{\partial}{\partial y}\left(K y y \frac{\partial h}{\partial y}\right)+\frac{\partial}{\partial z}\left(K z z \frac{\partial h}{\partial z}\right)-W=S s \frac{\partial h}{\partial t}
$$

where

$$
\begin{aligned}
& K_{x x}, K_{y y} \text {, and } K_{z z} \text { represent the hydraulic conductivity along } \\
& \text { the } x, y \text {, and } z \text { coordinate axes, which are } \\
& \text { assumed parallel to the major axes of } \\
& \text { hydraulic conductivity }\left(L t^{-1}\right) \text {; } \\
& h \quad \text { is hydraulic head }\left(L t^{-1}\right) \text {; } \\
& W \quad \text { is a volumetric flux per unit volume } \\
& \text { representing sources and/or sinks of } \\
& \text { water, with } W<0.0 \text { for flow out of the } \\
& \text { groundwater system and } W>0.0 \text { for flow } \\
& \text { in }\left(L t^{-1}\right) \text {; } \\
& L \text { is length; } \\
& t \quad \text { is time; and } \\
& L t^{1} \quad \text { is length divided by time }
\end{aligned}
$$

(Harbaugh and McDonald, 1996). This equation, with specification of appropriate boundary and initial conditions, constitutes a mathematical representation of the groundwaterflow system. In this application, the aquifer system was assumed to be horizontally isotropic; thus, there was no preferred direction of hydraulic conductivity in the horizontal.

The storage coefficient $\left(S_{s}\right)$ in equation 1 is particularly important in a confined and unlithified aquifer system like the Gulf Coast aquifer system. Because the aquifers do not have a rigid skeletal matrix, water is released not only from coarse-grained sediments like sand and gravel but also from fine-grained sediments like clay and silt. Therefore, the compressibility of water $\left(S_{w}\right)$ is necessarily considered, computed as

$$
S_{w}=S_{s w} \times b
$$

where

$S_{s w} \quad$ is specific storage due to compressibility of water $(L)$;

$\begin{aligned} S_{s w} & \text { is computed as } S_{s w}=\mathrm{q} \times g_{w} / E_{w}(L) ; \text { and } \\ b & \text { is thickness of the layer }(L)\end{aligned}$

where

$\theta \quad$ is porosity (dimensionless);

$\gamma_{w} \quad$ is unit weight of water (62.4 pounds [lb] per cubic foot $\left.\left[\mathrm{ft}^{3}\right]\right)$;

$E_{w} \quad$ is the bulk modulus of elasticity of water $\left(4.5 \times 10^{7} \mathrm{lb} / \mathrm{ft}^{2}\right)$; and

$L \quad$ is length (modified from Leake and Prudic, 1991). 
An additional important component of the aquifer system is the compressibility of the sediment skeleton, or $S_{k}$, computed as

$$
S_{k}=S_{s k} \times b,
$$

where

$$
\begin{gathered}
S_{s k} \quad \text { is specific storage due to compressibility of } \\
\text { water, and } \\
b \quad \text { is thickness of sediments (L) (modified from } \\
\text { Leake and Prudic, 1991). }
\end{gathered}
$$

As in equation 2, equation 3 is relevant to coarse- and fine-grained sediments, and thickness of the aquifer $(b)$ is present. Thus, as the thickness of the aquifer increases, the storage coefficient from compressibility of water $\left(S_{w}\right)$ and storage coefficient from compressibility of the sediment skeleton $\left(S_{k}\right)$ correspondingly increase, providing a greater volume of water from storage in the downdip areas of the aquifers along the coast. In the Layer-Property Flow package of MODFLOW (LPF), a single combined specific storage value, $S_{s}=S_{s w+} S_{s k}$, is specified and multiplied by layer thickness for the case where head is above the top of a model layer (confined conditions). Where the aquifer is unconfined (head is below the top of the layer), LPF applies a value of specific yield in formulation of the equations for groundwater flow. Use of the confined storage coefficient, $S$ $=S_{s} \times b$, is appropriate where compression and expansion of the aquifer skeleton and water are elastic; however, if inelastic (nonrecoverable) compaction of fine-grained sediments occurs and is important, an add-on package such as the SUB package (Hoffman and others, 2003) should be used with the no-delay interbeds option for the Gulf Coast aquifer system. For details on representing all storage properties in a model with aquifersystem compaction, see Leake and Prudic (1991).

\section{Grid Design}

The finite-difference grid (fig. 1) for the HAGM covers 33,565 square miles $\left(\mathrm{mi}^{2}\right)$ in southeastern Texas and southwestern Louisiana. The model grid was rotated 37.6 degrees clockwise so that the orientation of the model closely coincides with the natural groundwater divides, model boundaries, and predevelopment and postdevelopment flow paths. The four layers of the model together contain 134,260 grid blocks. Each layer consists of 137 rows and 245 columns. Layer 1 represents the Chicot aquifer, layer 2 the Evangeline aquifer, layer 3 the Burkeville confining unit, and layer 4 the Jasper aquifer. The grid blocks are uniformly spaced with each model cell area equal to $1 \mathrm{mi}^{2}$.

\section{Boundaries}

Model boundaries control where and how much water enters and exits the simulated aquifer system. The selection of model boundaries for the aquifers in this model was based on a conceptual interpretation of the flow system developed by using information reported by Meyer and Carr (1979), Carr and others (1985), Williamson and others (1990), and Strom and others (2003a, b, c). The northwestern boundaries of the three aquifers and the Burkeville confining unit are the northwestern extent of the updip outcrop sediments for each unit (Kasmarek and Robinson, 2004, figs. 8, 14, 20, 21). Northwest of these boundaries, the model grid blocks were assigned a hydraulic conductivity of zero to simulate no-flow boundaries. The downdip limit of freshwater (defined for this study as the location where the dissolved solids concentration is as much as 10,000 milligrams per liter $[\mathrm{mg} / \mathrm{L}]$ ) was chosen as the southeastern boundary of flow in each hydrogeologic unit. Southeast of these limits, the model grid blocks were assigned a hydraulic conductivity of zero to simulate no-flow boundaries. The location of the 10,000-mg/L line in each hydrogeologic unit was estimated from geophysical log data and from the coastward extent of freshwater withdrawals (Kasmarek and Robinson, 2004). A no-flow boundary at specified locations reflects an assumption of a stable downdip freshwater/saline-water interface. Along the coast in most of the HAGM study area, this assumption probably is valid: little or no human-induced stresses on the aquifer system in most of the coastal region likely have allowed long-term equilibrium to be established between the freshwater and the slightly more dense saline water that lies laterally adjacent to and beneath the freshwater. The southwestern and northeastern lateral boundaries for the Chicot, Evangeline, and Jasper aquifers and the Burkeville confining unit were selected to coincide with groundwater-flow divides associated with major rivers in the study area. The southwestern lateral boundary was located generally along the Lavaca River, and the northeastern lateral boundary was located in the general vicinity of the Sabine River (fig. 1). The assumption is that little lateral flow occurs across these boundaries, and thus they can reasonably be simulated as no-flow boundaries. The Catahoula confining system underlies the Jasper aquifer. The assumption is that the brackish water within the Catahoula confining system sufficiently impedes the exchange of water between the Jasper aquifer and deeper units, so the Catahoula confining system can reasonably be simulated as a no-flow base-of-system boundary.

\section{Recharge and Discharge}

The MODFLOW General-Head Boundary (GHB) package was used to simulate recharge and discharge in the outcrops of the Chicot, Evangeline, and Jasper aquifers and the Burkeville confining unit. This package allows the simulated water table of an aquifer system to function as a head-dependent flux (flow per unit area) boundary (Franke and others, 1987); that is, a condition in which the rate of flow between the water table and the adjacent deeper zone of the system is controlled by the difference between the water table (constant head) and the head in the adjacent deeper zone (which changes with model simulation time) and by the vertical hydraulic conductance between the water table and the immediately adjacent deeper zone. In interstream outcrop 
areas, the head differences indicate general downward flow or areas of recharge, and in stream and downdip areas along the coast, the head differences generally indicate upward flow or areas of discharge. Simulating the water table as a constant-head source (or sink) of water to the system requires an assumption that no long-term trends in the water table are indicated, as shown in the example hydrographs in Kasmarek and Robinson (2004, fig. 28). These hydrographs indicate that the water table remains stable even during documented periods of drought that occurred during 1932-34, 1938-40, 1947-48, 1950-57, and 1960-67 (State of Texas Drought Preparedness Council, 2006). Water-table-altitude data for the shallow zones of the hydrogeologic units from the model of Kasmarek and Robinson (2004) were used for HAGM model grid blocks in areas where the two models are coincident. These water-table-altitude data were originally created by using the method described by Williams and Williamson (1989) that used multiple linear regressions of depth-to-water data and topographic data to derive relations between depth to water and topography. This assumption is believed reasonable over most of the HAGM study area.

Flow between streams and the aquifer system (essentially discharge from aquifers to incised streams in outcrops) was not explicitly simulated in the model. The rationale for this approach is that the GHB package, assuming that the model is adequately calibrated, would account for stream discharge to the level of accuracy that such discharge is known. Additionally, few measured data are available on streamflow gains or losses for the major streams that flow across the outcrops of the Gulf Coast aquifer system. Because aquifer discharge to streams is not well known, such data are not particularly helpful for comparison with simulated data for purposes of calibration; there was little incentive to add more complexity to an already complex model by explicitly computing flow between streams to the aquifers. Although some additional recharge rates have recently been determined (Tarver, 1968; Sandeen, 1972; Loskot and others, 1982; Baker, 1986; and Kasmarek and Robinson, 2004), the additional complexity of including that information specifically, by substituting the GHB package with the River or Stream package and the Recharge package, was determined to be beyond the scope of this report.

\section{Initial Conditions}

Initial conditions, including heads and spatial distributions of hydraulic conductivity, leakance, sand storativity, clay storativity, and general-head boundary conductance from Kasmarek and Robinson (2004), provided the initial data before model calibration began. The leakance parameter is equivalent to vertical hydraulic conductivity divided by the vertical distance between the centers of model layers. The spatial distributions of head in each hydrogeologic unit for the initial predevelopment steady-state simulation also were coincident with Kasmarek and Robinson (2004). Additionally, the simulated values of head from the stress period associated with the year 2000 in the GAM (Kasmarek and Robinson, 2004) were consistent with the initial heads of the HAGM in year 2001. For more detailed information on the initial development of these datasets, refer to Kasmarek and Robinson (2004).

\section{Land-Surface Subsidence and Storage in Clays}

Simulation of land-surface subsidence (actually, compaction of clays) and release of water from storage in the clays of the Chicot, Evangeline, and Jasper aquifers and the Burkeville confining unit was accomplished by using the SUB package designed for use with MODFLOW-2000 by Hoffman and others (2003). As explained in Leake and Prudic (1991), effective stress is defined as the difference between geostatic pressure (overburden load) and fluid pressure (head). Head decreases in a confined aquifer do not change geostatic pressure if, as assumed in this application, watertable heads remain constant. With constant geostatic pressure, effective stress thus will increase by the same amount that heads decrease. Previous studies (Riley, 1969; Helm, 1975) indicate that compaction (or expansion) of interbedded clays is proportional, or nearly so, to change in effective stress. For sediments in confined aquifers with constant geostatic pressure, compaction also is proportional, or nearly so, to change in head. The relation is

$$
\Delta b=\Delta h S_{s} b_{o},
$$

where

$$
\begin{array}{cl}
\Delta b & \text { is the amount of compaction or expansion (L); } \\
\Delta h & \text { is the change in head (L); } \\
S_{s} & \text { is the skeletal (sand and clay) component of } \\
& \text { elastic or inelastic specific storage }\left(\mathrm{L}^{-1}\right) ; \\
b_{o} & \text { is the thickness of the interbed (L); and } \\
\mathrm{L} & \text { is length (modified from Leake and Prudic, } \\
& \text { 1991). }
\end{array}
$$

For changes in hydraulic head in which head remains above preconsolidation head, an elastic response is computed. For changes in head in which head declines below preconsolidation head, an inelastic response is computed, permanent clay compaction is calculated, and the preconsolidation head is reset to the new head value. For the HAGM, an initial value of preconsolidation head of about 70 $\mathrm{ft}$ below the starting head was used.

A preconsolidation head of about $70 \mathrm{ft}$ was used by Meyer and Carr (1979), Carr and others (1985), Kasmarek and Strom (2002), and Kasmarek and Robinson (2004). For the Chicot and Evangeline aquifers in the HAGM study area, the initial values of elastic- and inelastic-clay storativity were coincident with the model of Kasmarek and Robinson (2004). The initial values of elastic-clay storativity used in the HAGM for the Burkeville confining unit and the Jasper aquifer were calculated by multiplying existing GAM values of clay thickness by $1.0 \times 10^{-6}$. The initial values of inelasticclay storativity for the Burkeville confining unit and Jasper aquifer were derived by multiplying the values of elastic-clay storativity by 100 . 


\section{Withdrawals}

The primary sources of updated water-use data used in the HAGM are as follows: the Harris-Galveston Subsidence District (Harris and Galveston Counties); the Fort Bend Subsidence District (Fort Bend County); and the Lone Star Groundwater Conservation District, the Texas Water Development Board, and the San Jacinto River Authority (Montgomery County). HAGM simulations were made under transient conditions from 10,000 years before 1891 through 2009 for 78 groundwater withdrawal (stress) periods of variable length (fig. 8 and table 1). Stress period 1 has a long duration without withdrawals, thereby enhancing model stability prior to actual withdrawals that began in stress period 2 . For the years 1980, 1982, and 1988, monthly stress periods were applied. Substantially lower than average precipitation was recorded in the HAGM study area for those years. Monthly rather than annual stress periods allows the model to represent groundwater withdrawals on a monthly or seasonal basis if the model is used to simulate hypothetical drought scenarios in the future. Total groundwater withdrawals increased from an estimated $41 \mathrm{Mgal} / \mathrm{d}$ in 1891 to about 1,130 Mgal/d in 1976, peaked at about 1,135 Mgal/d in 1980, and varied during the next 20 years but generally trended downward to about $895 \mathrm{Mgal} / \mathrm{d}$ in 2000. Evaluation of these data indicates that groundwater withdrawals varied from $799 \mathrm{Mgal} / \mathrm{d}$ in 2001 to $869 \mathrm{Mgal} / \mathrm{d}$ in 2009. The lowest withdrawals, $747 \mathrm{Mgal} / \mathrm{d}$, occurred in 2007, and the highest withdrawals, $876 \mathrm{Mgal} / \mathrm{d}$, occurred in 2005. Historical water-use data supplied by the Texas Water Development Board (compiled by LBG-Guyton Associates) were used to update the 2001-9 data in Austin, Brazoria, Chambers, Hardin, Jefferson, Liberty, Matagorda, Walker, Waller, and Wharton Counties. For the remaining counties of the HAGM study area, water-use data were not updated for the period 2001-9 but were equal to and held constant during 2001-9 at the 2000 value of the GAM wateruse data of Kasmarek and Robinson (2004). Additional wateruse data were combined with the water-use data of the GAM for the Evangeline and Jasper aquifers in Montgomery County for the periods 1955-2000 and 1969-2000, respectively.

\section{Model Calibration}

Before calibration began, an initial predevelopment (no withdrawals) steady-state simulation was run to obtain starting heads for the hydrogeologic units for transient calibration simulations. Periodically during calibration, predevelopment steady-state simulations were run with the most current input data to obtain starting heads for successive transient calibration simulations. The input data that were adjusted from initial values on the basis of model output from successive transient simulations were hydraulic conductivity (transmissivity divided by aquifer thickness) of the aquifers, storativity of sands, vertical hydraulic conductance (leakance) between the water table and deeper zones of each hydrogeologic unit in outcrop areas, leakance between hydrogeologic units in subcrop areas, and inelastic-clay storativity (actually, inelastic-clay-specific storage, which is multiplied by aquifer or confining unit thickness) in the Chicot, Evangeline, and Jasper aquifers and the Burkeville confining unit. Water-table heads, hydraulic conductivity, and storativity of the Burkeville confining unit, storativity of the Jasper aquifer, and temporal and spatial distributions of withdrawals were adjusted. Elastic-specific storage of clays in the Chicot and Evangeline aquifers were computed by multiplying inelastic-clay storativities by 0.01 .

The HAGM was calibrated by an iterative trial-and-error adjustment of selected model input data (the aquifer properties that control water flow, recharge, discharge, and storage) in a series of transient simulations until the model output (simulated heads and land-surface subsidence and selected water-budget components) reasonably reproduced field measured (or estimated) aquifer responses and specified model calibration criteria. Transient model calibration comprised eight elements:

1. qualitative comparison of simulated and measured potentiometric surfaces of the Chicot, Evangeline, and Jasper aquifers for 2009 (Kasmarek, Houston, and Ramage, 2009);

2. quantitative comparison of simulated water levels and annually measured water levels of selected wells screened in the Chicot, Evangeline, and Jasper aquifers (calibration targets) by computing and evaluating the areal distribution of the root-mean-square error (RMSE) (square root of the sum of the squares of the differences between simulated and measured heads divided by the total number of calibration targets) of 497 sites for the three aquifers for 2009;

3. qualitative comparison of hydrographs of simulated and measured water levels for each aquifer;

4. quantitative comparison of simulated and measured subsidence by computation and areal distribution of the RMSE for 474 calibration target sites was performedRMSE values were calculated by using standard GIS techniques, whereby a gridded surface of the 2000 land-surface subsidence data (Gabrysch and Neighbors, 2005) was intersected with the simulated subsidence data for model cells coinciding with the locations of the 474 calibration targets, providing a spatial distribution of RMSE;

5. qualitative comparison of simulated subsidence from the 1890s through 2000 was compared to measured cumulative long-term land-surface subsidence from 1906 to 2000 (Gabrysch and Neighbors, 2005);

6. qualitative comparison of simulated predevelopment potentiometric surfaces of the aquifers to conceptualized configurations of the predevelopment surfaces based on hydrogeologic knowledge of the Gulf Coast aquifer system; 


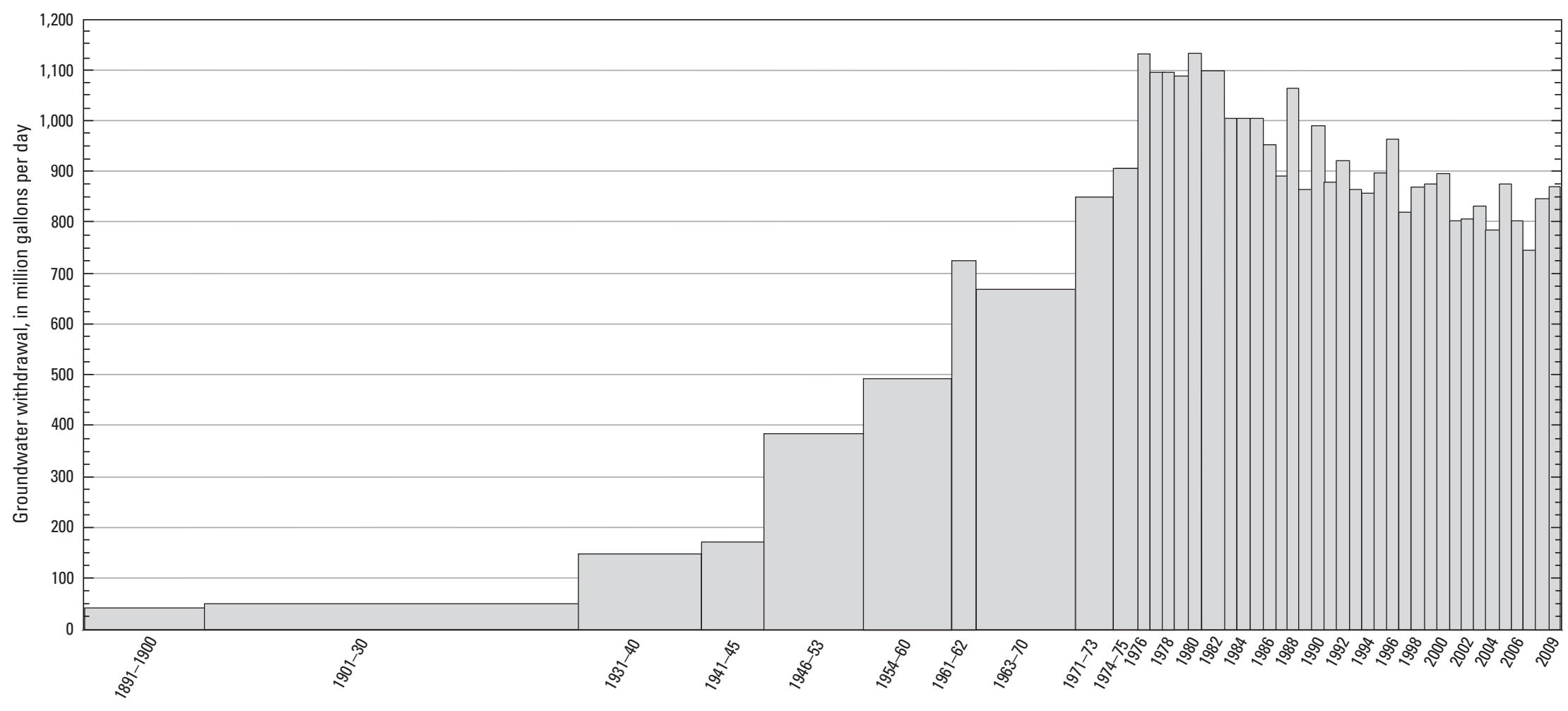

Stress periods, in years (table 1)

Figure 8. Total groundwater withdrawals used during transient Houston Area Groundwater Model simulations, by stress periods, 1891-2009 
Table 1. Groundwater withdrawal (stress) periods used in the Houston Area Groundwater Model.

\begin{tabular}{|c|c|c|c|c|c|c|c|c|}
\hline $\begin{array}{l}\text { Stress } \\
\text { period }\end{array}$ & $\begin{array}{l}\text { Length } \\
\text { of time } \\
\text { (years) }\end{array}$ & $\begin{array}{l}\text { Time } \\
\text { interval }\end{array}$ & $\begin{array}{l}\text { Stress } \\
\text { period }\end{array}$ & $\begin{array}{l}\text { Length } \\
\text { of time } \\
\text { (years) }\end{array}$ & $\begin{array}{c}\text { Time } \\
\text { interval }\end{array}$ & $\begin{array}{l}\text { Stress } \\
\text { period }\end{array}$ & $\begin{array}{l}\text { Length } \\
\text { of time } \\
\text { (years) }\end{array}$ & $\begin{array}{l}\text { Time } \\
\text { interval }\end{array}$ \\
\hline 1 & Steady state $^{1}$ & 10,000 years & 27 & 0.085 & Dec. 1980 & 53 & 0.085 & Aug. 1988 \\
\hline 2 & 10 & 1891-1900 & 28 & 1 & 1981 & 54 & 0.082 & Sept. 1988 \\
\hline 3 & 30 & 1901-30 & 29 & 0.085 & Jan. 1982 & 55 & 0.085 & Oct. 1988 \\
\hline 4 & 10 & $1931-40$ & 30 & 0.077 & Feb. 1982 & 56 & 0.082 & Nov. 1988 \\
\hline 5 & 5 & $1941-45$ & 31 & 0.085 & Mar. 1982 & 57 & 0.085 & Dec. 1988 \\
\hline 6 & 8 & $1946-53$ & 32 & 0.082 & Apr. 1982 & 58 & 1 & 1989 \\
\hline 7 & 7 & 1954-60 & 33 & 0.085 & May 1982 & 59 & 1 & 1990 \\
\hline 8 & 2 & $1961-62$ & 34 & 0.082 & June 1982 & 60 & 1 & 1991 \\
\hline 9 & 8 & $1963-70$ & 35 & 0.085 & July 1982 & 61 & 1 & 1992 \\
\hline 10 & 3 & 1971-73 & 36 & 0.085 & Aug. 1982 & 62 & 1 & 1993 \\
\hline 11 & 2 & $1974-75$ & 37 & 0.082 & Sept. 1982 & 63 & 1 & 1994 \\
\hline 12 & 1 & 1976 & 38 & 0.085 & Oct. 1982 & 64 & 1 & 1995 \\
\hline 13 & 1 & 1977 & 39 & 0.082 & Nov. 1982 & 65 & 1 & 1996 \\
\hline 14 & 1 & 1978 & 40 & 0.085 & Dec. 1982 & 66 & 1 & 1997 \\
\hline 15 & 1 & 1979 & 41 & 1 & 1983 & 67 & 1 & 1998 \\
\hline 16 & 0.085 & Jan. 1980 & 42 & 1 & 1984 & 68 & 1 & 1999 \\
\hline 17 & 0.077 & Feb. 1980 & 43 & 1 & 1985 & 69 & 1 & 2000 \\
\hline 18 & 0.085 & Mar. 1980 & 44 & 1 & 1986 & 70 & 1 & 2001 \\
\hline 19 & 0.082 & Apr. 1980 & 45 & 1 & 1987 & 71 & 1 & 2002 \\
\hline 20 & 0.085 & May 1980 & 46 & 0.085 & Jan. 1988 & 72 & 1 & 2003 \\
\hline 21 & 0.082 & June 1980 & 47 & 0.077 & Feb. 1988 & 73 & 1 & 2004 \\
\hline 22 & 0.085 & July 1980 & 48 & 0.085 & Mar. 1988 & 74 & 1 & 2005 \\
\hline 23 & 0.085 & Aug. 1980 & 49 & 0.082 & Apr. 1988 & 75 & 1 & 2006 \\
\hline 24 & 0.082 & Sept. 1980 & 50 & 0.085 & May 1988 & 76 & 1 & 2007 \\
\hline 25 & 0.085 & Oct. 1980 & 51 & 0.082 & June 1988 & 77 & 1 & 2008 \\
\hline 26 & 0.082 & Nov. 1980 & 52 & 0.085 & July 1988 & 78 & 1 & 2009 \\
\hline
\end{tabular}

${ }^{1}$ A 10,000-year steady-state period was used for model stability.

7. quantitative comparison of simulated water-budget components - primarily recharge and withdrawal rates. The simulated recharge rate was compared to the range of rates from previous recharge studies (see "Ground-WaterFlow Conditions, Recharge, and Discharge" section in Kasmarek and Robinson, 2004) to ensure that the value was reasonable. Similarly, simulated groundwater withdrawal rates were compared to the cumulative withdrawal rates published by HGSD, FBSD, and LSGCD for accuracy. Additionally, comparisons of simulated spatial distributions of recharge and discharge in the outcrops of aquifers to estimates of physically reasonable distributions based on knowledge of the hydrology of the Gulf Coast aquifer system also were used.

8. quantitative determination to ensure that the calibrated RMSE for each aquifer is 10 percent or less of the total range of calibrated simulated head.
Calibrated model parameters of the four layers of the GAM (Kasmarek and Robinson, 2004) and HAGM were compared to quantify the parameter differences (table 2). The additional water-use data (2001-9) used in the HAGM since the GAM was finalized required modification of the calibrated parameters, particularly in layer 4 (Jasper aquifer), to achieve recalibration.

The maximum value of simulated GHB conductance in layer 1 (Chicot aquifer) was decreased by more than two orders of magnitude, but the minimum value was increased by two orders of magnitude. All other maximum and minimum values of conductance in layer 2 (Evangeline aquifer), layer 3 (Burkeville confining unit), and layer 4 (Jasper aquifer) were unchanged (table 2).

The maximum value of inelastic-clay storativity (inelastic storage coefficient) was increased by about one order of magnitude in layer 1 and was increased by about two 
Table 2. Comparison of calibrated-parameter values used in the Groundwater Availability Model (GAM) (2004) and the Houston Area Groundwater Model (HAGM).

[min, minimum; max, maximum; GHB, general head boundary; ICS, inelastic-clay storativity; HC, hydraulic conductivity; $\mathrm{ft}$, feet; $\mathrm{ft}^{2} / \mathrm{day}$, square feet per day; $\mathrm{n} / \mathrm{s}$, not simulated; <, less than; $\mathrm{n} / \mathrm{a}$, not applicable; $\mathrm{ft}^{3} /$ day, cubic feet per day]

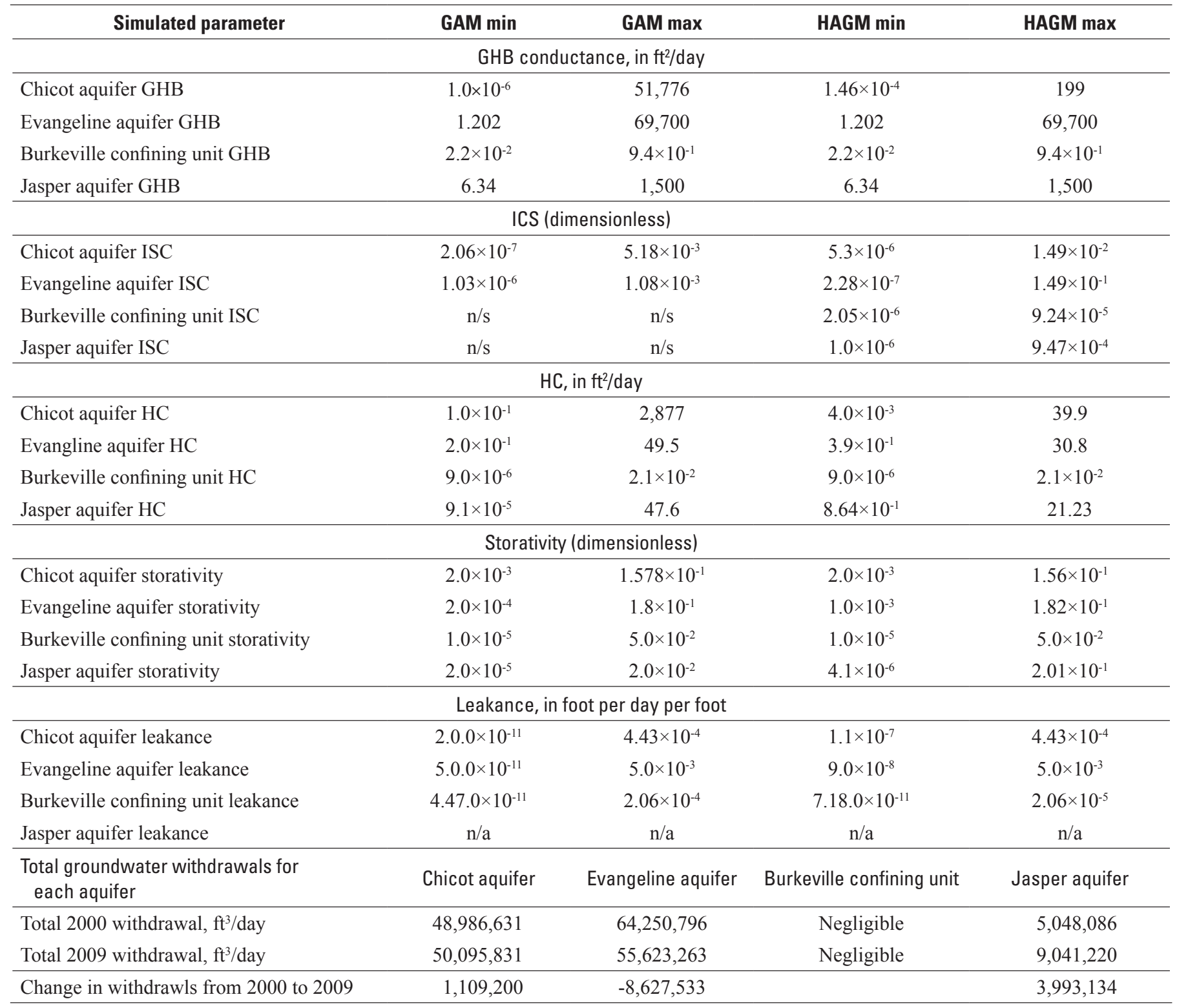

orders of magnitude for layer 2 . The minimum inelastic-clay storativity was increased by about one order of magnitude in layer 1 but decreased by about one order of magnitude in layer 2. A comparison of inelastic-clay storativity values for layers 3 and 4 was not possible because clay compaction was not simulated for these layers in the GAM.

The maximum value of simulated hydraulic conductivity (HC) value decreased about two orders of magnitude in layer 1 , decreased slightly for layer 2 , remained constant in layer 3 , and decreased by about half in layer 4 . The minimum
$\mathrm{HC}$ was decreased by about two orders of magnitude for the layer 1 , increased slightly for layer 2 , remained the same for the layer 3 , and increased by about three orders of magnitude for layer 4 .

The maximum value of simulated storativity (sand storage) remained about constant for layers 1, 2, and 3 but increased by about one order of magnitude for layer 4 . The minimum values of storativity for layers 1 and 3 remained constant, increased by about one order of magnitude for layer 2 , and decreased by about one order of magnitude for layer 4 . 
The maximum value of simulated leakance for layers 1 , 2, and 3 remained constant between the GAM and HAGM calibrated models. The minimum leakance in layer 1 was increased by about four orders of magnitude, was increased by about three orders of magnitude in layer 2, and remained about constant in layer 3. Additionally, a comparison of groundwater withdrawals for 2000 and 2009 for the four model layers indicates withdrawals increased by $1,109,200$ cubic feet per day $\left(\mathrm{ft}^{3} / \mathrm{d}\right)$ for layer 1 , decreased by $8,627,533 \mathrm{ft}^{3} / \mathrm{d}$ for layer 2 , and increased by $3,993,134 \mathrm{ft}^{3} /$ day for layer 4 . Water-use data for the Burkeville confining unit were unreported, therefore unknown, but are thought to be negligible.

\section{Model Results}

\section{Simulated Hydraulic Properties Associated with Groundwater Flow and Subsidence}

The calibrated spatial distributions of simulated hydraulic conductivity in the Chicot, Evangeline, and Jasper aquifers are shown in figures 9-11 and listed in table 2. Hydraulic conductivities of the Chicot aquifer ranged from $4.0 \times 10^{-3}$ to $39.91 \mathrm{ft} / \mathrm{d}$, with the larger values located in Harris, Fort Bend, Liberty, Chambers, Galveston, Wharton, Colorado, Tyler, Jasper, and Newton Counties. Hydraulic conductivities of the Evangeline aquifer ranged from $3.9 \times 10^{-1}$ to $30.79 \mathrm{ft} / \mathrm{d}$, with largest values located in southeast Fort Bend County. Hydraulic conductivities of the Burkeville confining unit are coincident with values used in the GAM (Kasmarek and Robinson, 2004). Hydraulic conductivities of the Jasper aquifer ranged from $8.64 \times 10^{-1}$ to $21.23 \mathrm{ft} / \mathrm{d}$, with the larger values located in northern Harris and Montgomery Counties. Spatial distributions of hydraulic conductivity indicate that, generally, the largest values are coincident with areas of large withdrawals and are consistent with previous studies (Wesselman, 1972; Jorgensen, 1975; Carr and others, 1985; Baker, 1986; Kasmarek and Strom, 2002; Ryder and Ardis, 2002; see "Initial Conditions," Kasmarek and Robinson, 2004).

Simulated sand storativities of the Chicot and Evangeline aquifers $\left(2.0 \times 10^{-3}\right.$ to $1.56 \times 10^{-1}$ and $1.0 \times 10^{-3}$ to $1.82 \times 10^{-1}$, figs. 12 and 13, respectively) reflect aquifer conditions from confined to semiconfined to water table. Sand storativities of the Chicot and Evangeline aquifers (figs. 12 and 13) generally are largest in the updip, outcrop areas, where water-table conditions prevail. Storativities of the Burkeville confining unit are coincident with values used in the GAM (Kasmarek and Robinson, 2004). Storativities of the Jasper aquifer $\left(4.1 \times 10^{-6}\right.$ to $\left.2.01 \times 10^{-1}\right)$ are generally largest in the updip, outcrop areas associated with water-table conditions (fig. 14).

The simulated calibrated spatial distributions of inelasticclay storativity for the Chicot aquifer, the Evangeline aquifer, the Burkeville confining unit, and the Jasper aquifer are shown in figures 15-18, respectively. Because a large area of land-surface subsidence has been documented (Gabrysch and Neighbors, 2005; Kasmarek, Gabrysch, and Johnson, 2009) in Harris County and parts of Galveston, Fort Bend, Montgomery, Brazoria, Waller, Liberty, and Chambers Counties, only these areas of the model study area can be considered calibrated for elastic- and inelastic-clay storativity. Inelastic-clay storativities for the Chicot aquifer, the Evangeline aquifer, the Burkeville confining unit, and the Jasper aquifer range from $5.3 \times 10^{-6}$ to $1.49 \times 10^{-2}$, from $2.28 \times 10^{-7}$ to $1.49 \times 10^{-1}$, from $2.05 \times 10^{-6}$ to $9.24 \times 10^{-5}$, and from $1.0 \times 10^{-6}$ to $9.47 \times 10^{-4}$, respectively. A total of 474 calibrationtarget sites in Harris and surrounding counties were used to evaluate simulated subsidence compared to measured subsidence. After numerous iterative trial-and-error transient model simulations, the final RMSE was $0.37 \mathrm{ft}$.

The simulated potentiometric surfaces of the Chicot, Evangeline, and Jasper aquifers for 2009 (figs. 19-21; also shown are the selected wells used as calibration targets) indicate general agreement with measured potentiometric surfaces from Kasmarek, Houston, and Ramage (2009). The simulated 2009 potentiometric surfaces of the aquifers are shown in this report, but the simulated potentiometric surfaces for 1977, 1990, and 2000 compare favorably with coincident published water-level-altitude maps for 1977 (Gabrysch, 1979); 1990 (Kasmarek, 1997); and 2000 (Coplin and Santos, 2000: Chicot and Evangeline aquifer water-level altitudes; Kasmarek and Houston, 2007: 2000 Jasper aquifer water-level altitude). The RMSE of the simulated water levels for the three aquifers for 2009 were about $31.06 \mathrm{ft}$ for the Chicot aquifer, about $33.73 \mathrm{ft}$ for the Evangeline aquifer, and about $23.50 \mathrm{ft}$ for the Jasper aquifer (table 3 ). The RMSE were calculated to be about 6,5 , and 4 percent, respectively, for the total range in simulated heads for the three aquifers, with a -0.03 percent water-budget difference between the total simulated inflow and the total simulated outflow.

Water levels were measured from December 2008 through March 2009 in wells completed in the Chicot, Evangeline, and Jasper aquifers (Kasmarek, Houston, and Ramage, 2009). Simulated heads were compared to measured heads to evaluate the calibration validity of the groundwaterflow model. This comparison of simulated and measured heads of the Chicot aquifer, 2009 (fig. 22), indicates that the model is acceptable throughout the range of measured heads; however, simulated heads are lower than measured heads for values of measured head from about $+60 \mathrm{ft}$ to about -120 $\mathrm{ft}$. Similarly, for the simulated and measured heads of the Evangeline aquifer, 2009 (fig. 22), the model is acceptable throughout the range of heads, but simulated heads are lower than measured heads for values of measured head from about $-105 \mathrm{ft}$ to about $-235 \mathrm{ft}$. Comparisons of simulated and measured heads for the Jasper aquifer, 2009 (fig. 22), indicate close correlation. These graphical comparisons between the simulated and measured heads correlate well with the RMSE shown in table 3 . 


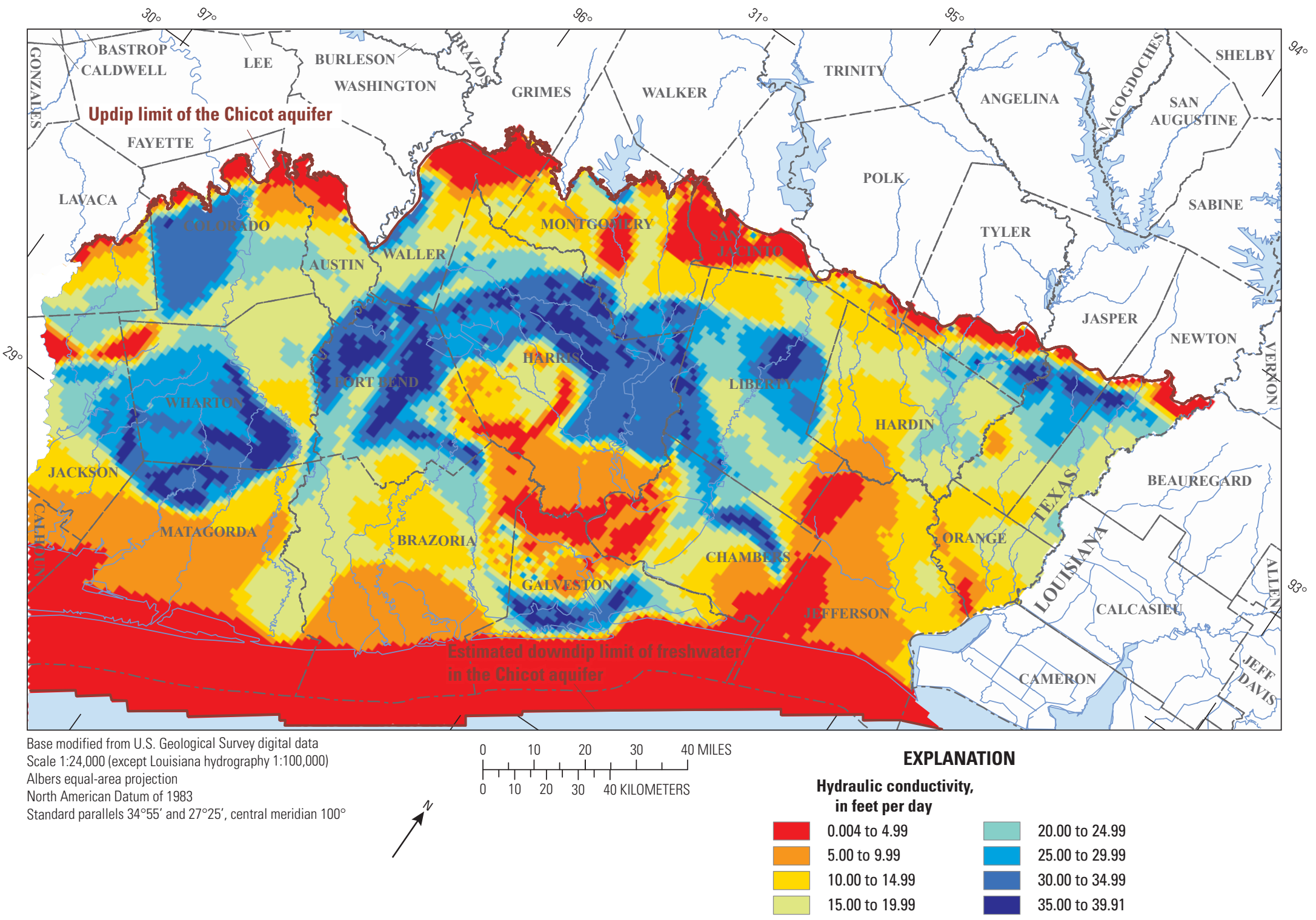

Figure 9. Simulated hydraulic conductivity of the Chicot aquifer in the Houston Area Groundwater Model study area. 


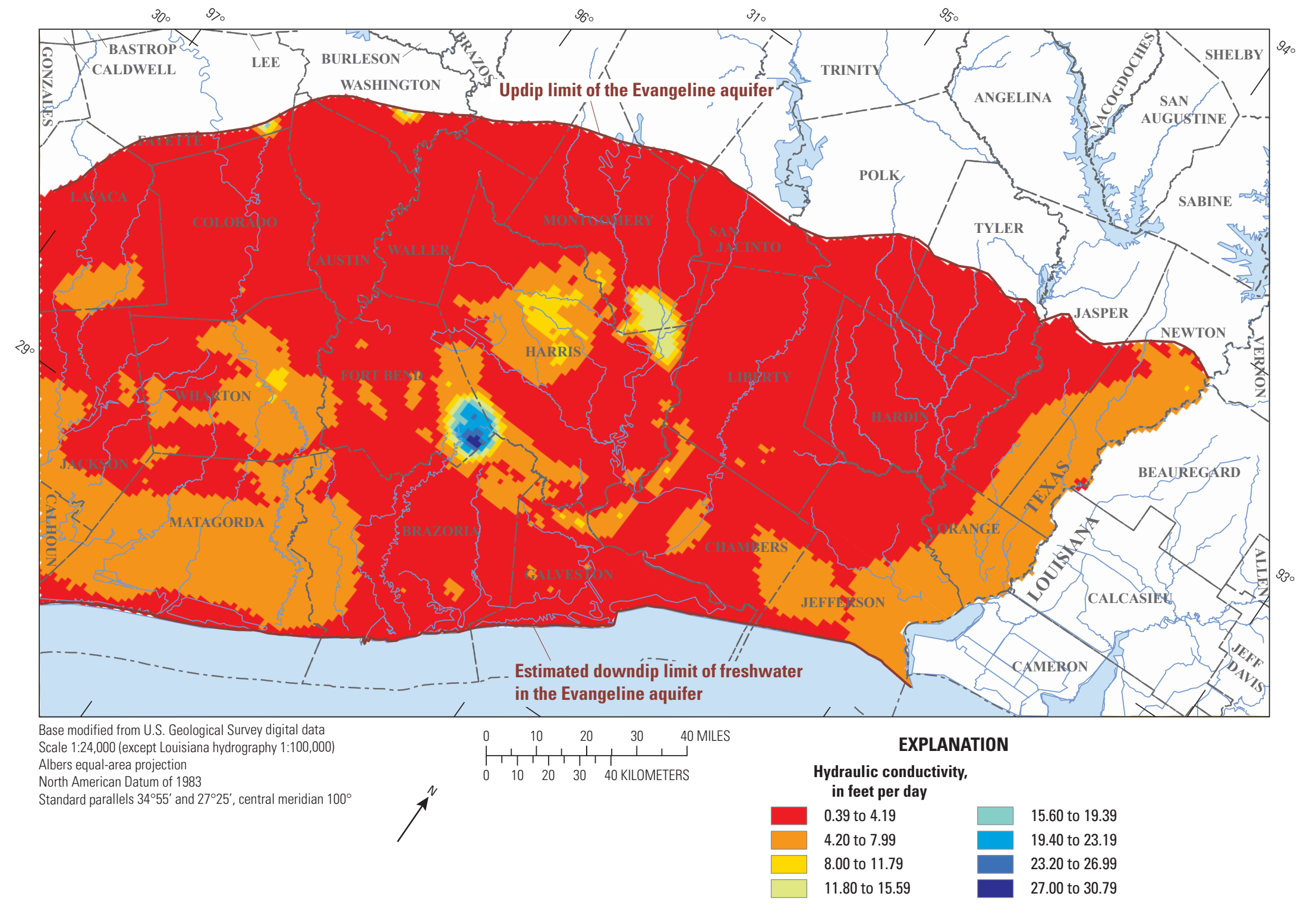




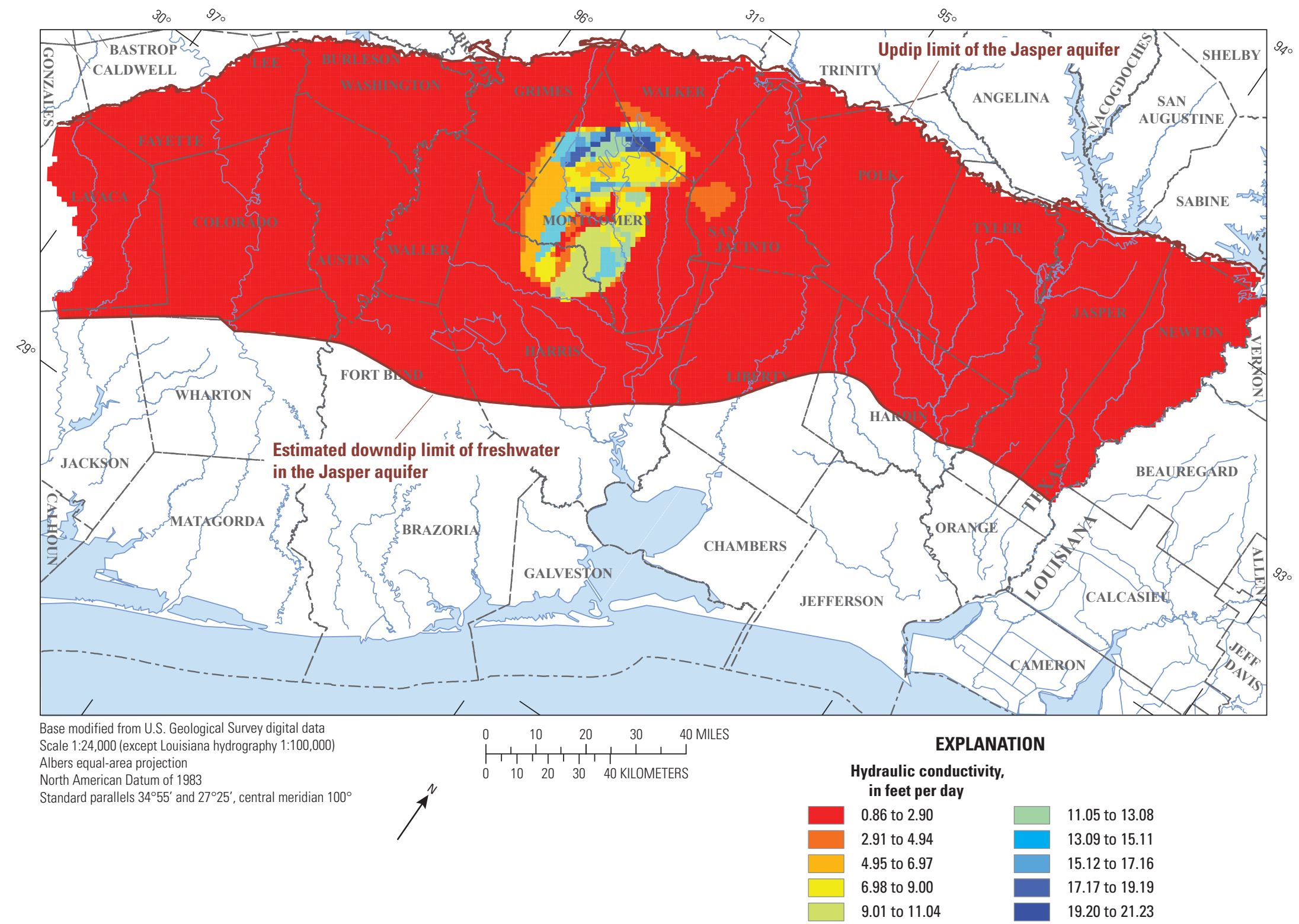

Figure 11. Simulated hydraulic conductivity of the Jasper aquifer in the Houston Area Groundwater Model study area. 


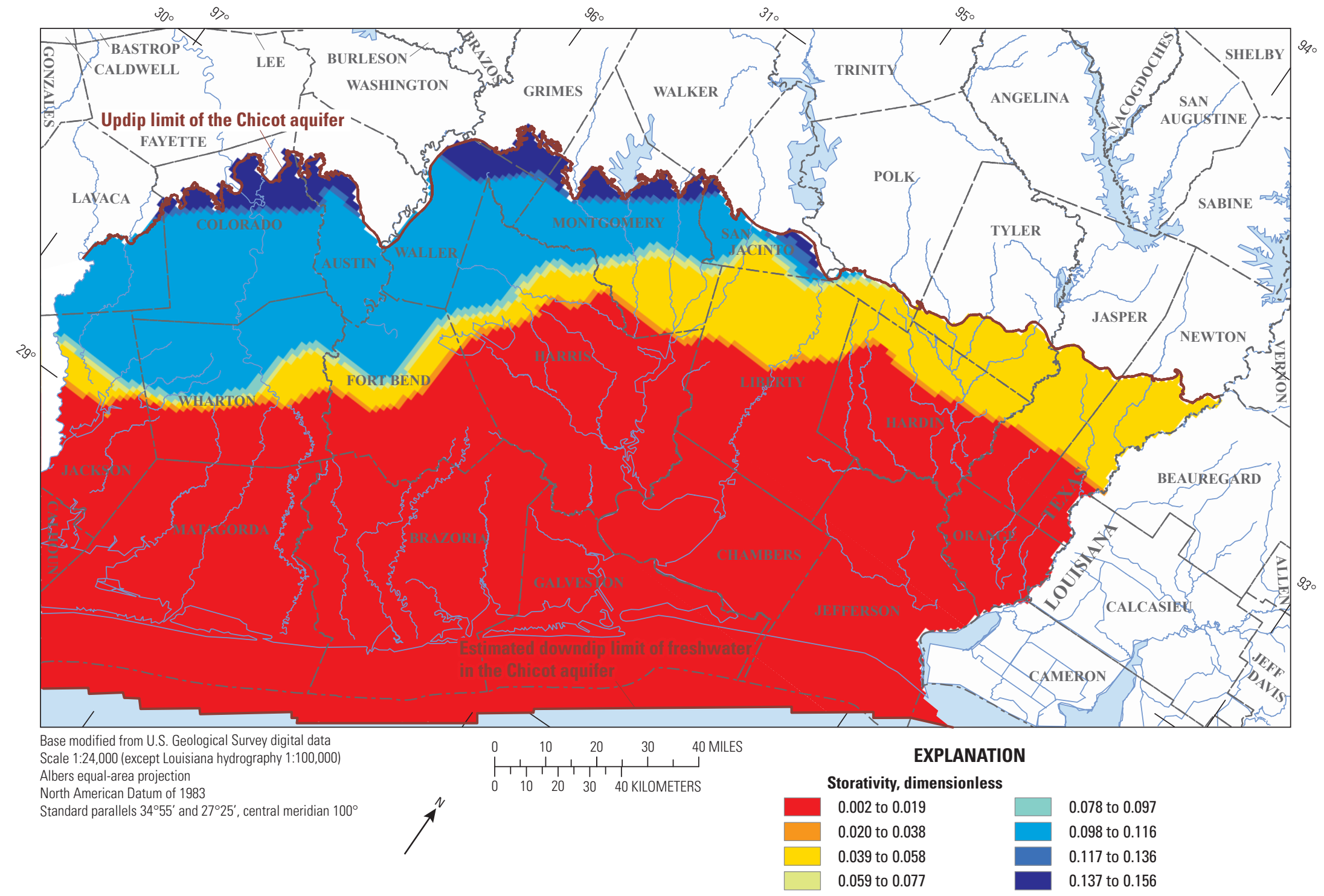




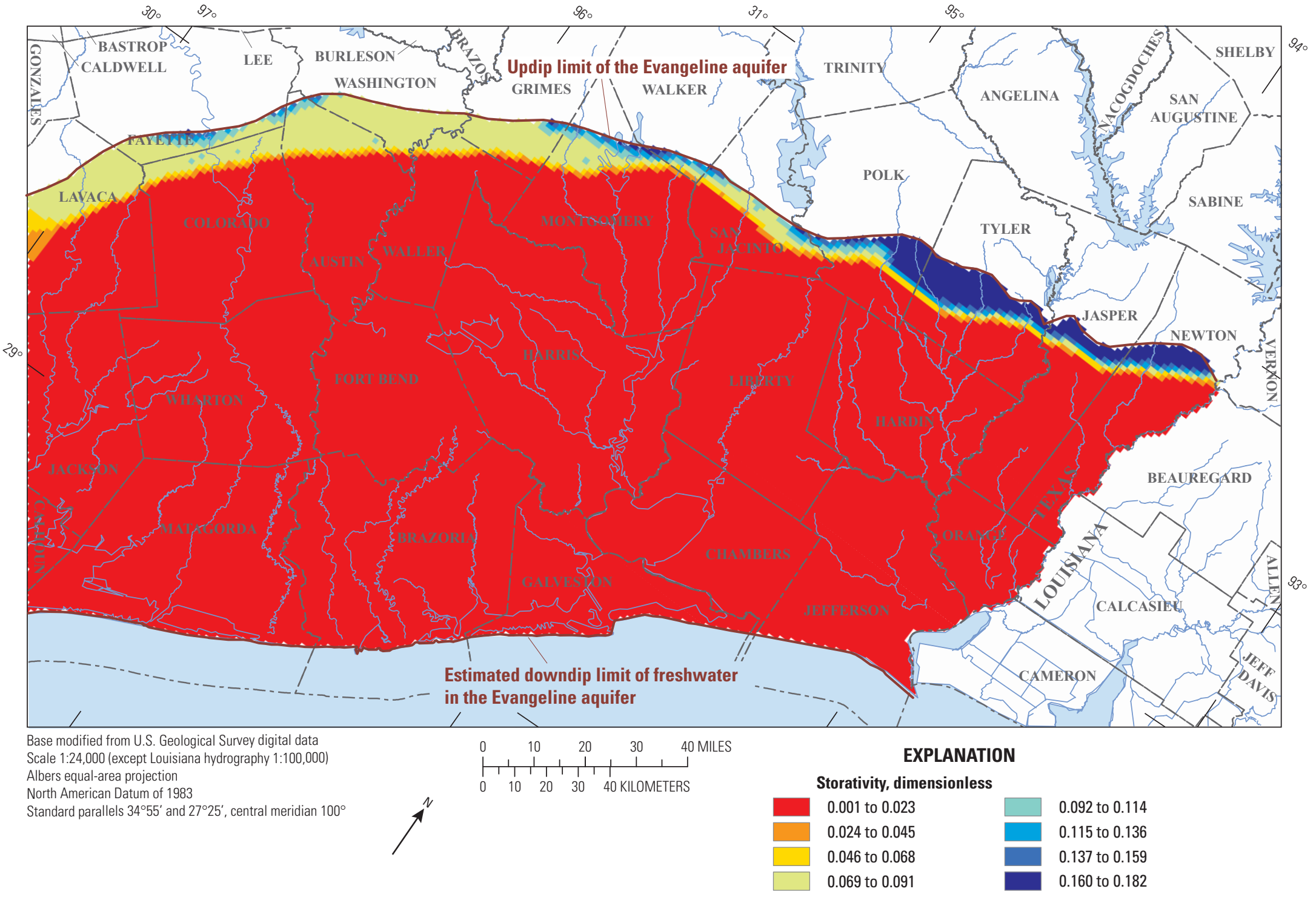

Figure 13. Simulated sand storativity of the Evangeline aquifer in the Houston Area Groundwater Model study area. 


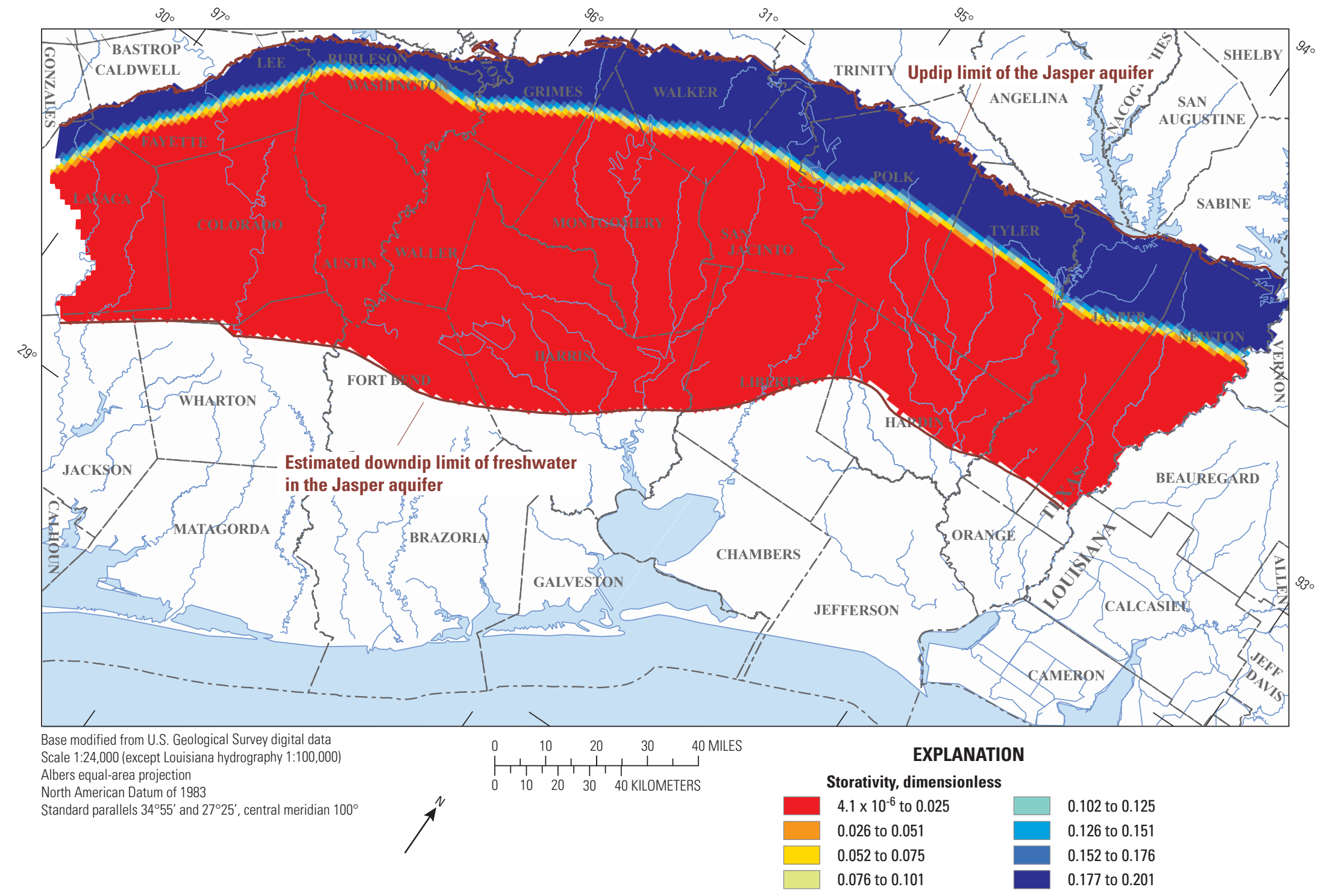




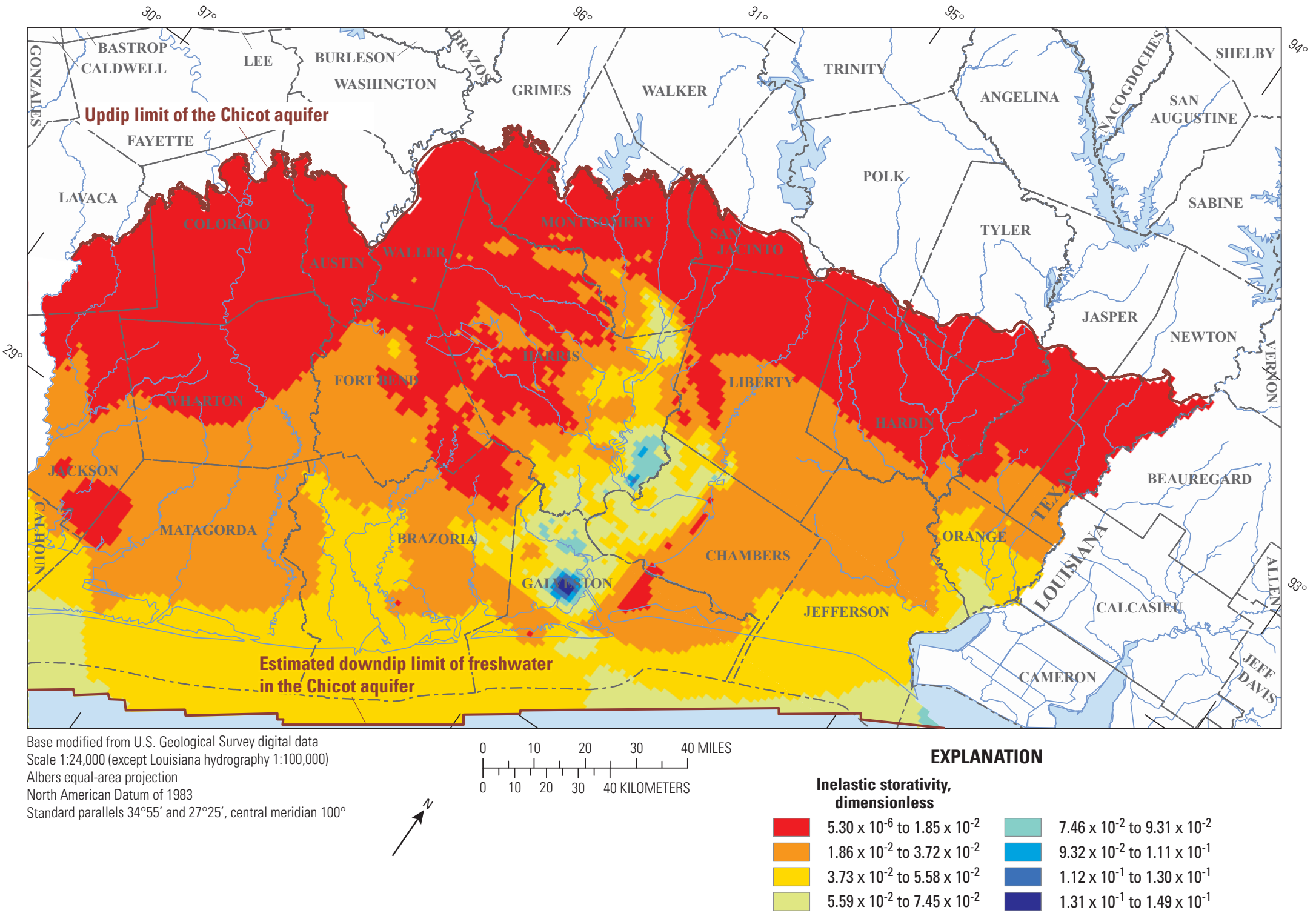

Figure 15. Simulated inelastic-clay storativity of the Chicot aquifer in the Houston Area Groundwater Model study area. 


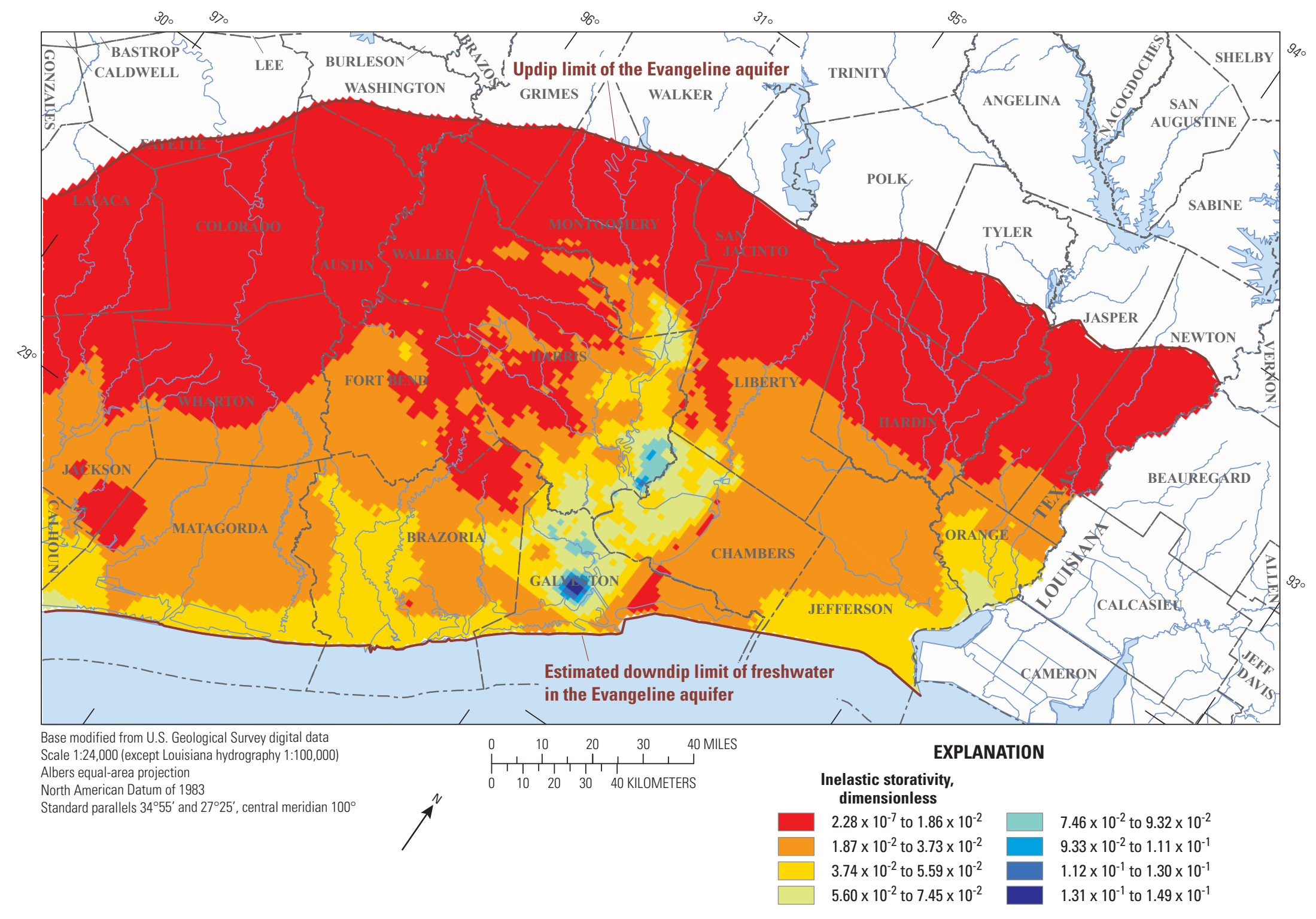




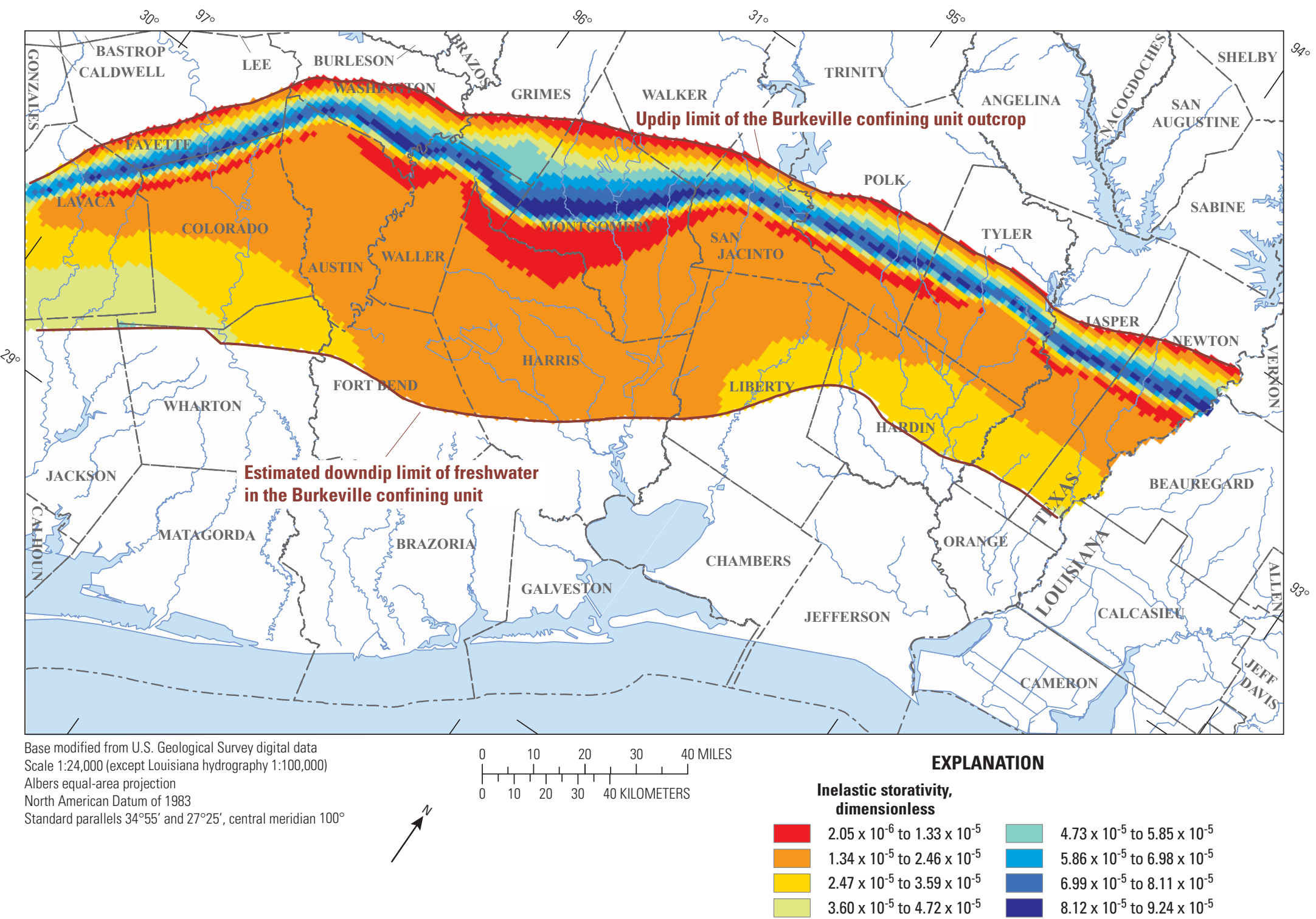

Figure 17. Simulated inelastic-clay storativity of the Burkeville confining unit in the Houston Area Groundwater Model study area. 


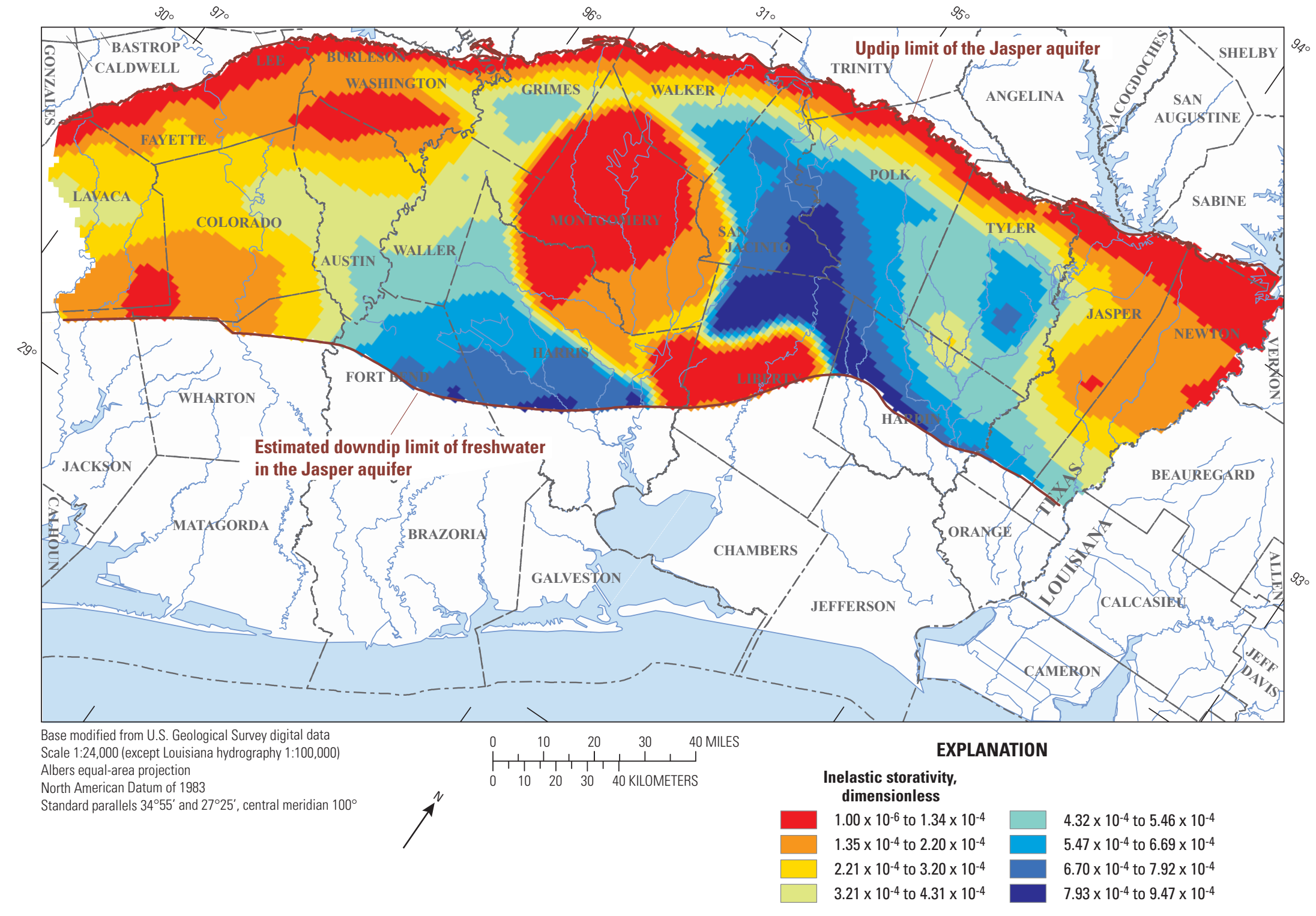




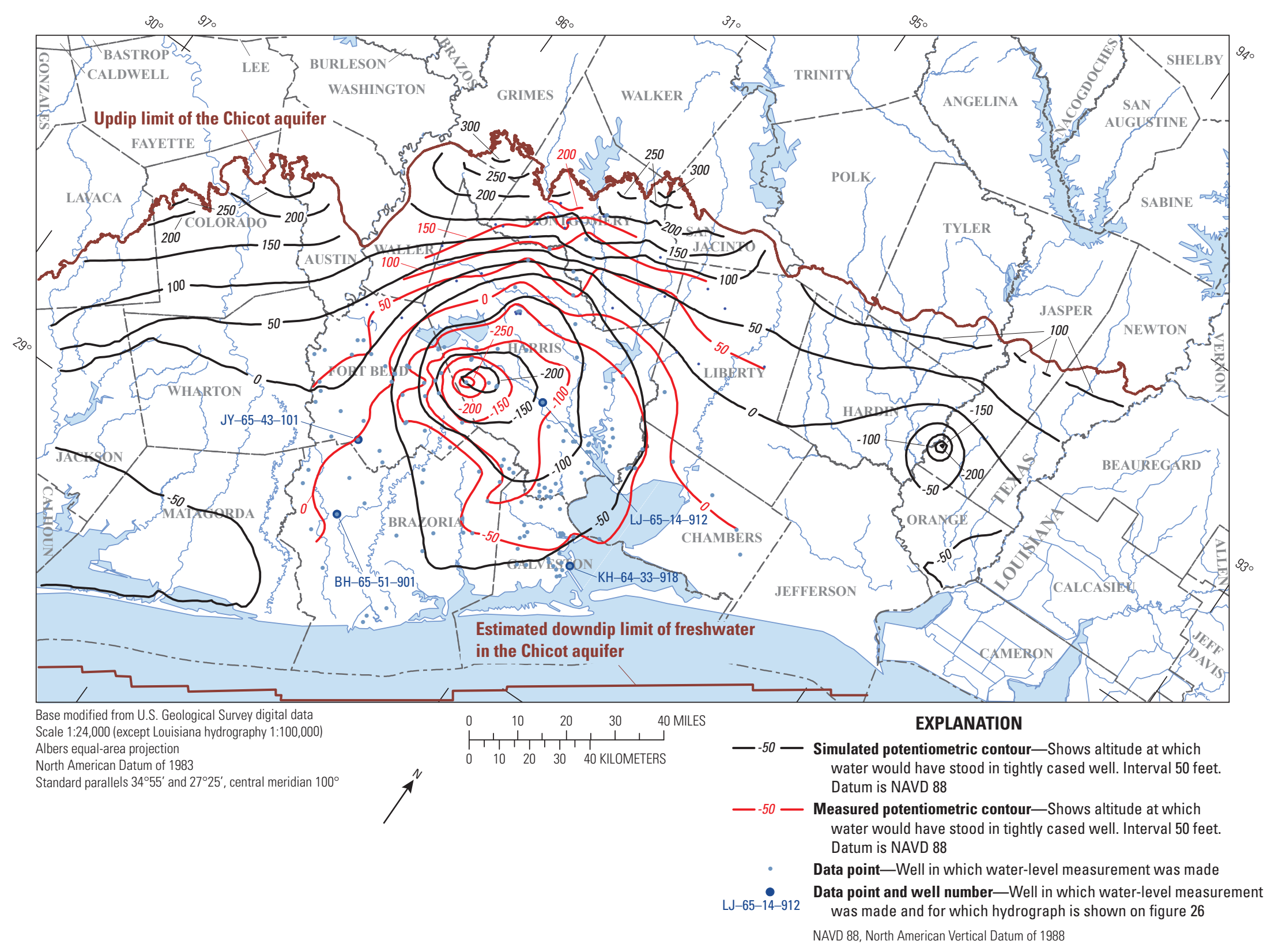

Figure 19. Simulated and measured potentiometric surfaces of the Chicot aquifer, 2009, and location of monitoring wells in the Houston Area Groundwater Model study area. 


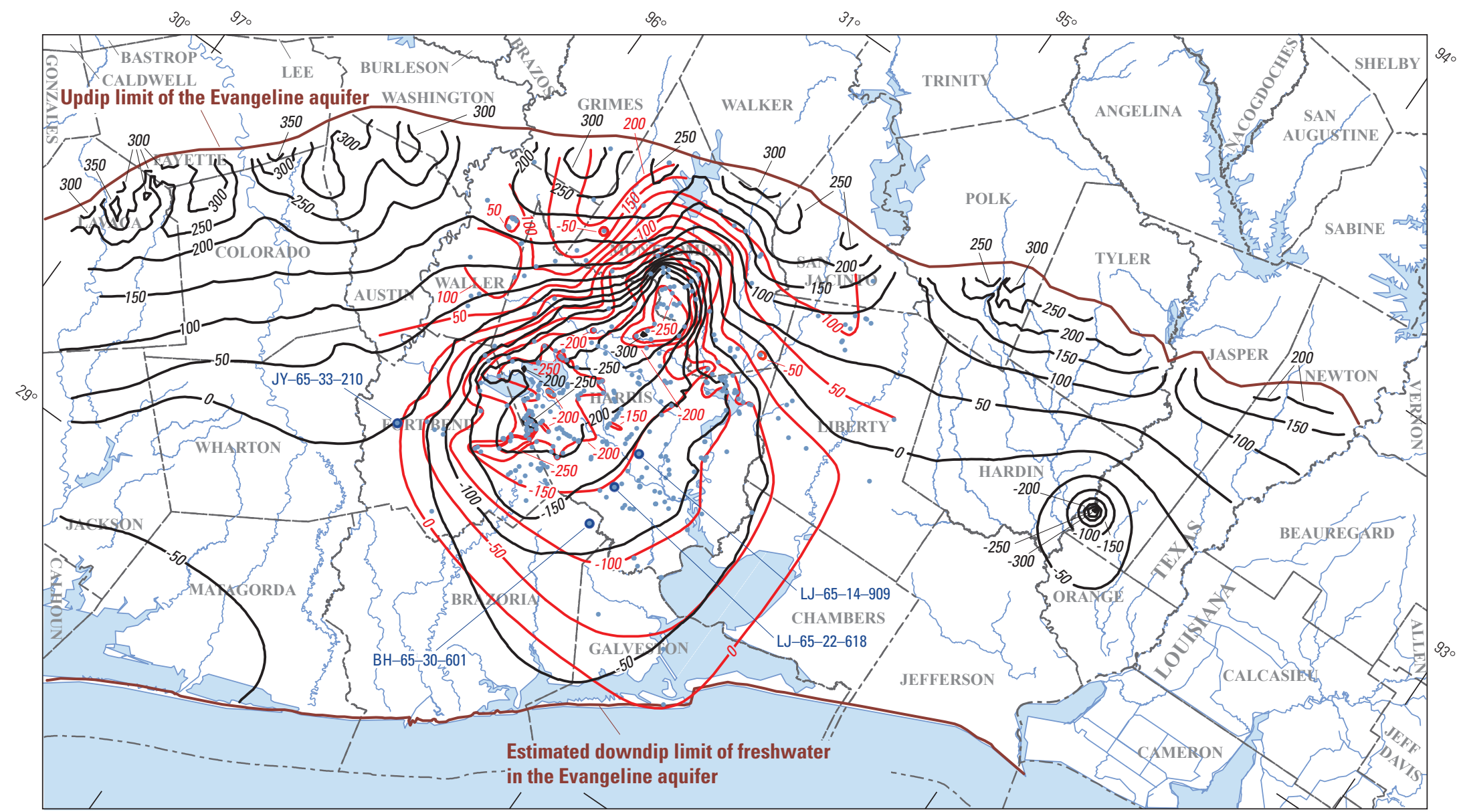

Base modified from U.S. Geological Survey digital data Scale 1:24,000 (except Louisiana hydrography 1:100,000 Albers equal-area projection

Standard parallels $34^{\circ} 55^{\prime}$ and $27^{\circ} 25^{\prime}$, central meridian $100^{\circ}$

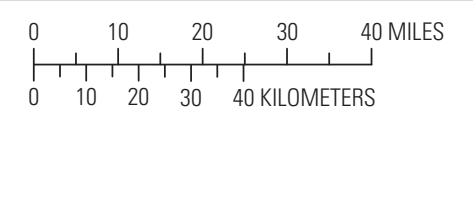

EXPLANATION

- -50 - Simulated potentiometric contour-Shows altitude at which water would have stood in tightly cased well. Interval 50 feet. Datum is NAVD 88

—-50 — Measured potentiometric contour-Shows altitude at which water would have stood in tightly cased well. Intervals 50,100 , and 250 feet. Datum is NAVD 88

- Data point-Well in which water-level measurement was made

-65-14-909 Data point and well number-Well in which water-level measurement was made and for which hydrograph is shown on figure 27 NAVD 88, North American Vertical Datum of 1988

Figure 20. Simulated and measured potentiometric surfaces of the Evangeline aquifer, 2009, and location of monitoring wells in the Houston Area Groundwater Model study 


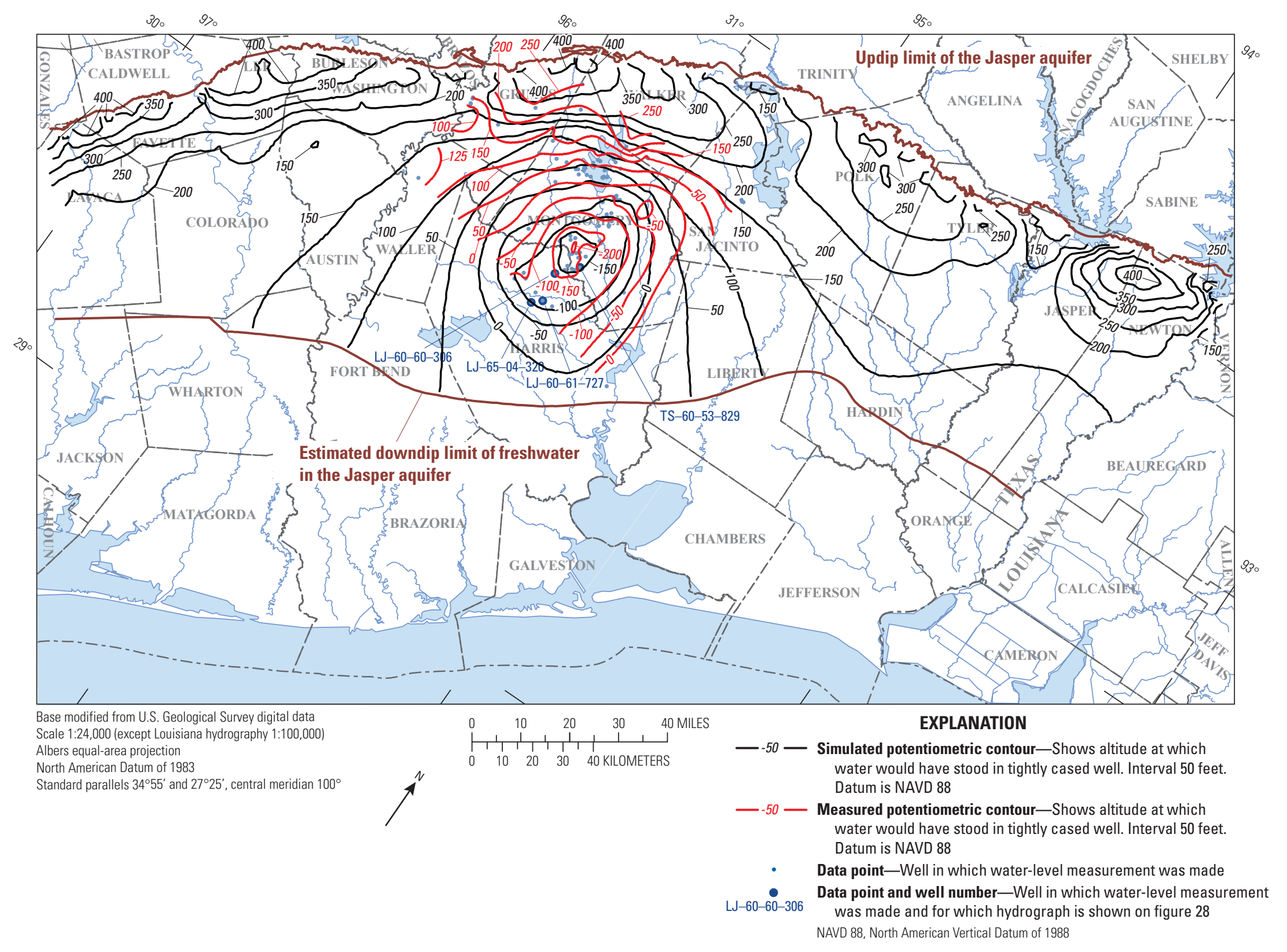

Figure 21. Simulated and measured potentiometric surfaces of the Jasper aquifer, 2009, and location of monitoring wells in the Houston Area Groundwater Model study area. 
Table 3. Number of water-level (head) measurements, root-meansquare errors of simulated head, and range of total simulated head in the Chicot, Evangeline, and Jasper aquifers, 2009.

\begin{tabular}{lccc}
\hline Aquifer & $\begin{array}{c}\text { Number of } \\
\text { water-level } \\
\text { measurements }\end{array}$ & $\begin{array}{c}\text { Root-mean- } \\
\text { square error } \\
\text { of simulated } \\
\text { water levels } \\
\text { (feet) }\end{array}$ & $\begin{array}{c}\text { Range of total } \\
\text { simulated head } \\
\text { (feet) }\end{array}$ \\
\hline Chicot & 165 & 31.06 & 366 \\
Evangeline & 251 & 33.73 & 541 \\
Jasper & 81 & 23.50 & 631 \\
\hline
\end{tabular}

The spatial distribution of water-level residuals (measured values of head minus simulated values of head) for the Chicot aquifer (fig. 23) indicates that most residuals are positive in the area of the model that contains monitoring wells, which means that the model computes head below the measured value. In other areas of the Fort Bend, Brazoria, Galveston, southwest Harris, Chambers, Liberty and Montgomery Counties, areas of negative and positive residual values are prevalent, which means that the model computes head above the measured value in these areas. From a spatial distribution of water-level (head) residuals for the Evangeline aquifer (fig. 24), most of the residuals are positive, with isolated areas of negative residuals in southeast Harris, northern Galveston, western Chambers, northern Waller, and southeast Grimes Counties; an area of negative residuals also extends from northern Waller County into Montgomery County. The spatial distribution of water-level (head) residuals for the Jasper aquifer (fig. 25) indicates an almost even distribution between negative and positive residuals. These residual values are less than residual values of the Chicot and Evangeline aquifers (figs. 23 and 24).

\section{Simulated and Measured Hydrographs}

Hydrographs of simulated and measured water levels for observation wells in Brazoria, Galveston, Harris, and Fort Bend Counties in wells screened in the Chicot aquifer (fig. 26) indicate that simulated and measured water levels match closely. The hydrographs for Galveston and Harris Counties (fig. 26B and $C$ ) reflect generally declining heads through the mid- to late 1970s followed by rises associated with decreased withdrawals. The hydrographs of simulated and measured water levels in observation wells in Brazoria and Fort Bend Counties for the Evangeline aquifer (fig. 27A and $B$ ) also match closely. The two hydrographs from wells in Harris County (fig. 27C and $D$ ) indicate similar matches between simulated and measured water levels from about 1998 through 2009, which spans the calibration period used for the HAGM. The hydrographs of simulated heads and measured heads in observation wells in Harris and Montgomery Counties for the Jasper aquifer (fig. 28) have similar water-level trends and become almost coincident in the mid-2000s.

\section{Simulated and Estimated Water-Budget Components}

Simulated recharge and discharge in outcrops of the hydrogeologic units, vertical leakage between units, changes in storage, and withdrawals for 2009 are summarized in figure 29. The diagram indicates a net recharge (total recharge minus natural discharge) of 779.6 cubic feet per second $\left(\mathrm{ft}^{3} / \mathrm{s}\right)$ (about $0.56 \mathrm{in} . / \mathrm{yr}$ ) in the Chicot aquifer outcrop, $35.0 \mathrm{ft}^{3} / \mathrm{s}$ (about $0.23 \mathrm{in} . / \mathrm{yr}$ ) in the Evangeline aquifer outcrop, negligible net recharge in the Burkeville confining unit outcrop, and $16.5 \mathrm{ft}^{3} / \mathrm{s}$ (about $0.07 \mathrm{in} . / \mathrm{yr}$ ) in the Jasper aquifer outcrop. For the entire system, the simulated total net recharge for 2009 was $831.1 \mathrm{ft}^{3} / \mathrm{s}$ (about $0.45 \mathrm{in} . / \mathrm{yr}$ ) in the outcrop areas. As a comparison, the simulated total recharge for the GAM in 2000 was $995 \mathrm{ft}^{3} / \mathrm{s}$ (about 0.54 in./yr) (Kasmarek and Robinson, 2004, p. 90). In terms of a water-budget balance (within $0.4 \mathrm{ft}^{3} / \mathrm{s}$ because of rounding error) for the entire system in $2009,945.2 \mathrm{ft}^{3} / \mathrm{s}$ of total recharge plus $391.9 \mathrm{ft}^{3} / \mathrm{s}$ from depletion of water in coarse-grained sediments (sands) and $104.8 \mathrm{ft}^{3} / \mathrm{s}$ from inelastic compaction of clays is offset by $114.1 \mathrm{ft}^{3} / \mathrm{s}$ of natural discharge and 1,328.2 $\mathrm{ft}^{3} / \mathrm{s}$ (about $858.4 \mathrm{Mgal} / \mathrm{d}$ ) of groundwater withdrawal. The net difference between total recharge $\left(945.2 \mathrm{ft}^{3} / \mathrm{s}\right)$ and withdrawal $\left(1,328.2 \mathrm{ft}^{3} / \mathrm{s}\right)$ is $383.0 \mathrm{ft}^{3} / \mathrm{s}$ (about $247.5 \mathrm{Mgal} / \mathrm{d}$ ), and the volume of withdrawal from the Chicot, Evangeline, and Jasper aquifers was about 44, 48, and 8 percent, respectively. The volumetric budget (expressed in cubic feet per day) for the transient simulation for the HAGM in 2009, at the end of stress period 78 , is shown in table 4 .

\section{Simulated and Measured Land-Surface Subsidence}

Simulated land-surface subsidence from 1891 (predevelopment) to 2000 and measured land-surface subsidence from 1906 to 2000 is shown in figure 30. In Harris County and counties immediately adjacent, where the main area of subsidence has been measured, the simulated and measured values of subsidence match closely. As much as 10 $\mathrm{ft}$ of measured subsidence has occurred in southeastern Harris County. A larger geographic area encompassing the maximum measured land-surface subsidence area and much of central to southeastern Harris County has subsided at least $6 \mathrm{ft}$. In the western part of the HAGM study area, another area of simulated subsidence centered in Wharton County has as much as $3 \mathrm{ft}$ of subsidence. In the eastern part of the HAGM study area, at the boundary of Hardin and Jasper Counties, an area of subsidence with as much as $3 \mathrm{ft}$ of subsidence was simulated. An isolated area with as much as $3 \mathrm{ft}$ of simulated subsidence is located in southeast Orange County. Measured subsidence has not been 


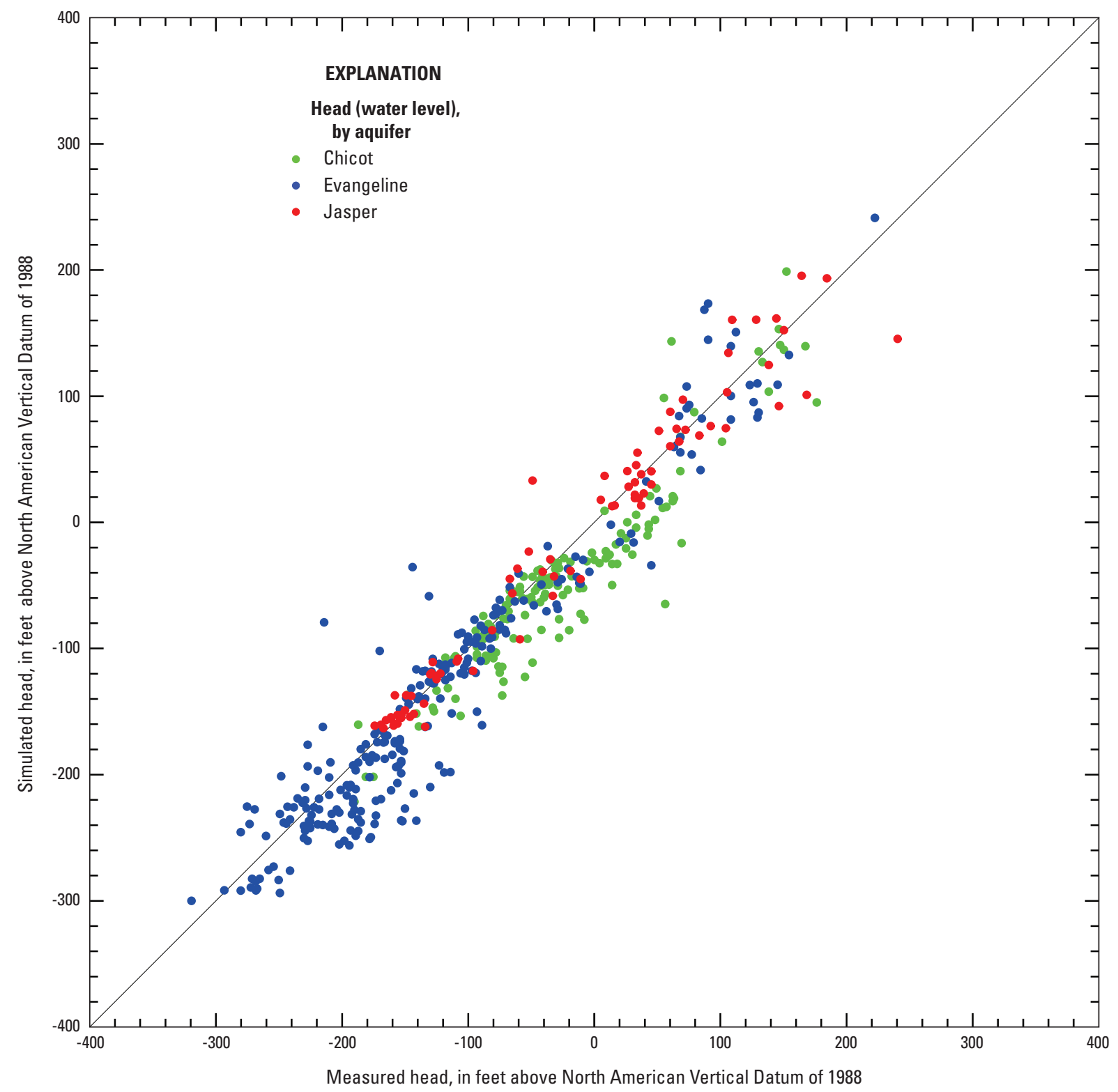

Figure 22. Relation between simulated and measured heads for the Chicot, Evangeline, and Jasper aquifers, 2009, in the Houston Area Groundwater Model study area.

documented for these western and eastern areas of the HAGM study area. Measured compaction of subsurface sediments at 11 borehole extensometer sites in Harris and Galveston Counties has been continually recorded since as early as 1973 (Kasmarek and others, 2009).

Simulated land-surface subsidence (1891-2009) and measured land-surface subsidence (1906-2000) is shown in figure 31. For these periods in Harris County and counties immediately adjacent, where the main area of measured subsidence is present, the simulated and measured subsidence match closely, but not as closely as in figure 30 . The most recent areas of simulated subsidence are generally in southern Montgomery, northwest Harris, and Fort Bend Counties, where water demand has increased and has resulted in sustained groundwater withdrawals during 2001-9. The two distal areas with as much as $3 \mathrm{ft}$ of simulated subsidence in the eastern and western areas of the HAGM study area depicted in figure 31 are similar to the areal extent of simulated subsidence shown for 2000 in figure 30 . 


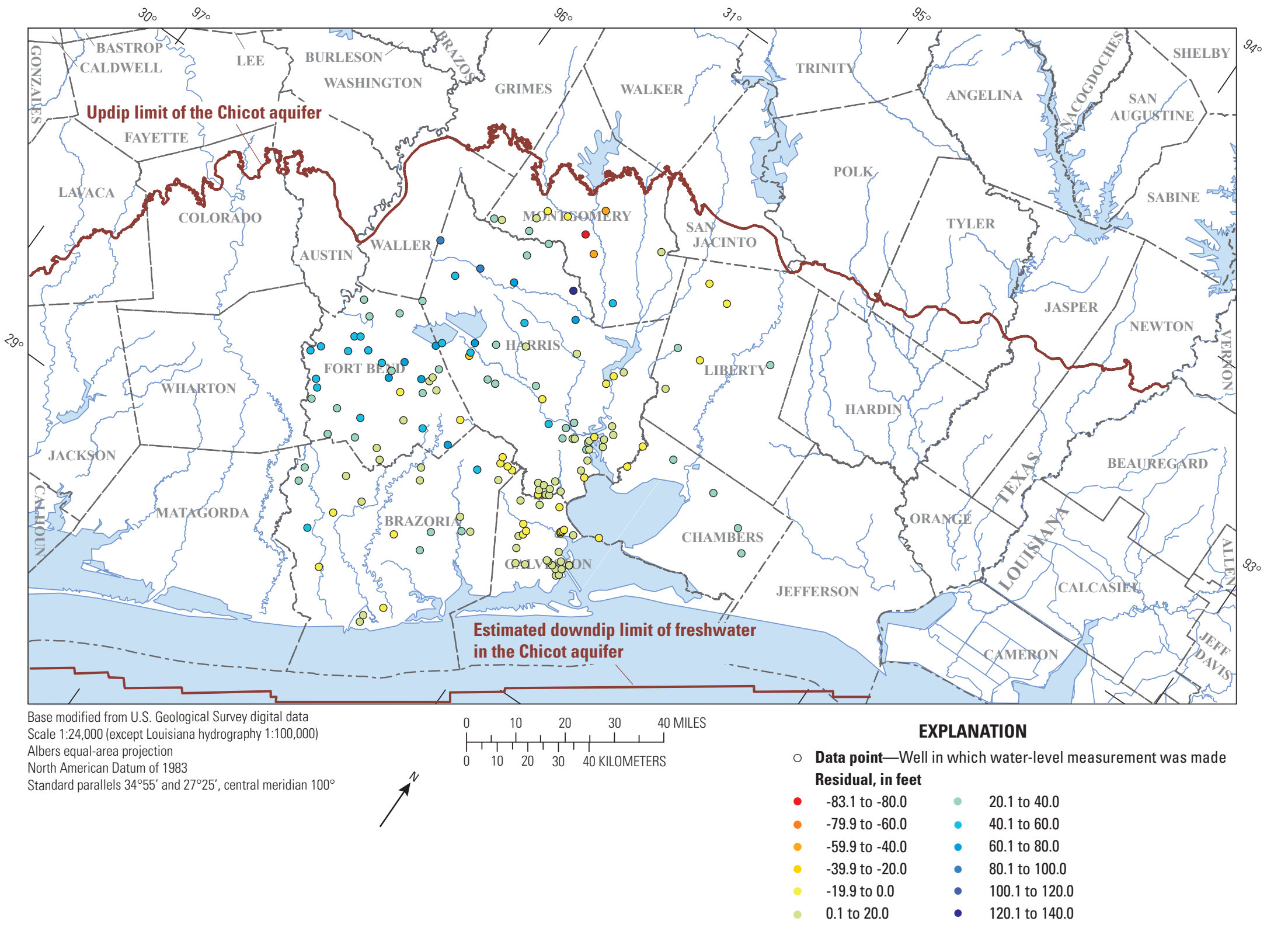

Figure 23. Spatial distribution of water-level (head) residuals (measured minus simulated heads) for the Chicot aquifer, 2009, in the Houston Area Groundwater Model study area. 


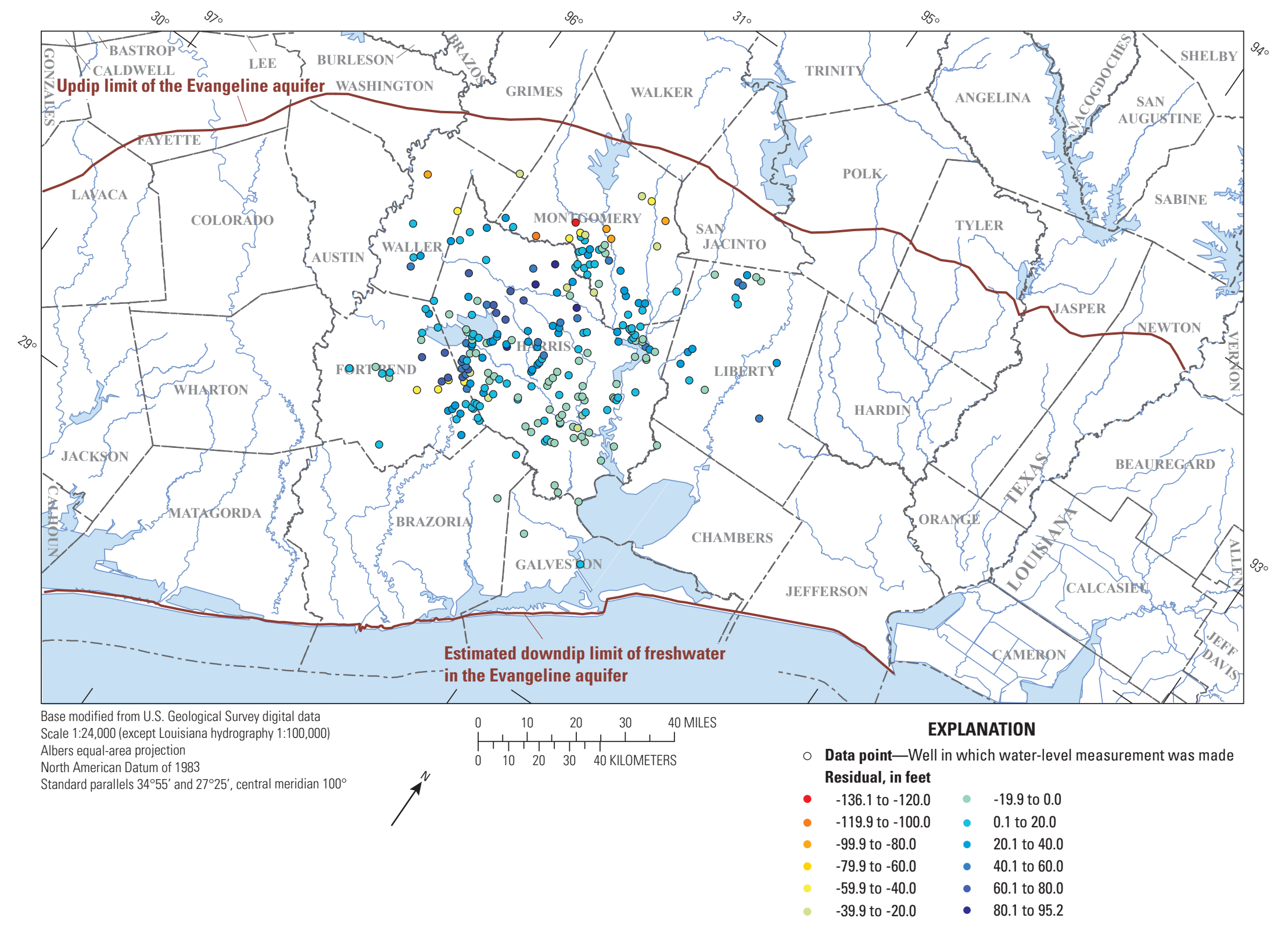

Figure 24. Spatial distribution of water-level (head) residuals (measured minus simulated heads) for the Evangeline aquifer, 2009, in the Houston Area Groundwater Model study area. 


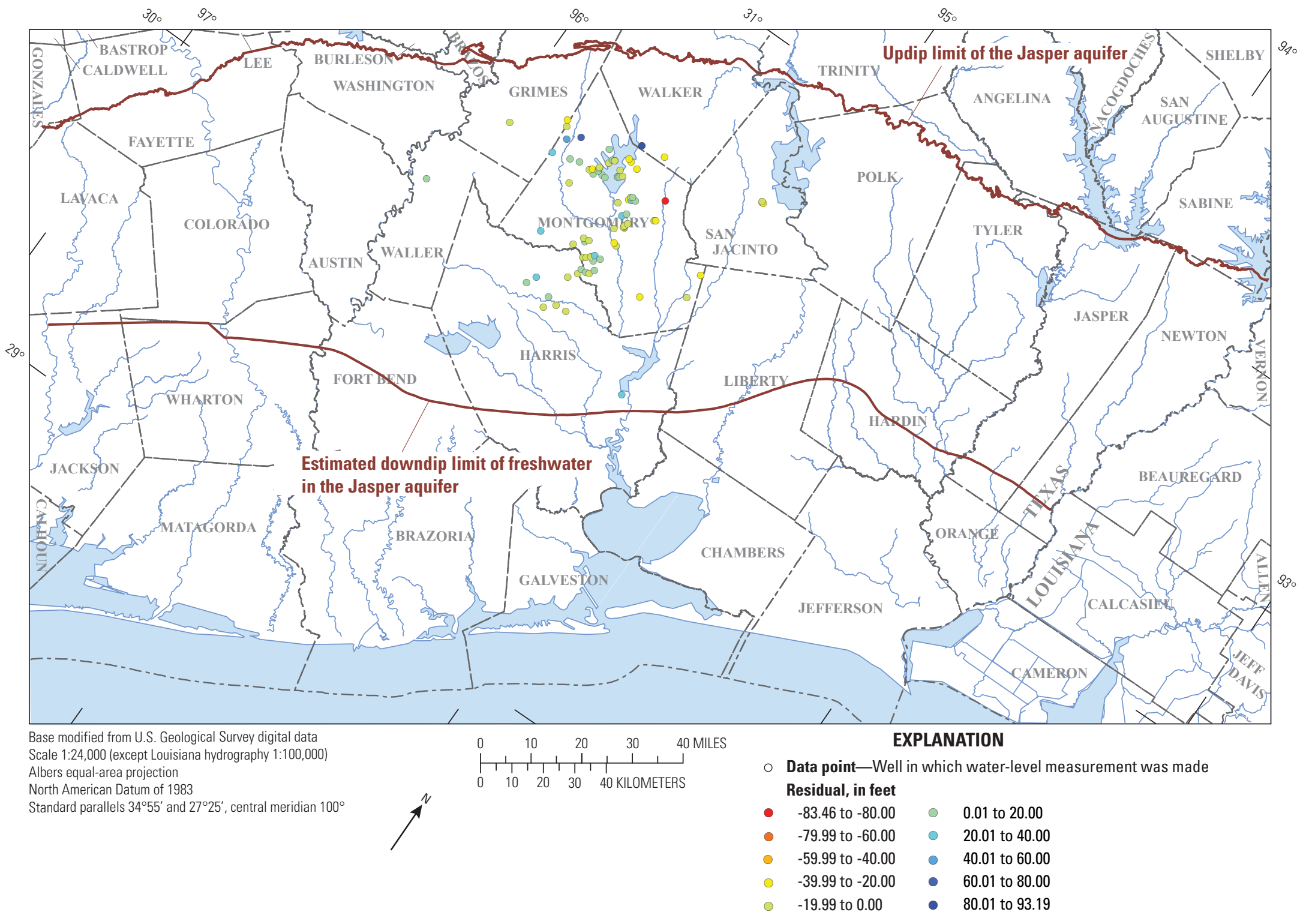

Figure 25. Spatial distribution of water-level (head) residuals (measured minus simulated heads) for the Jasper aquifer, 2009, in the Houston Area Groundwater Model study area. 

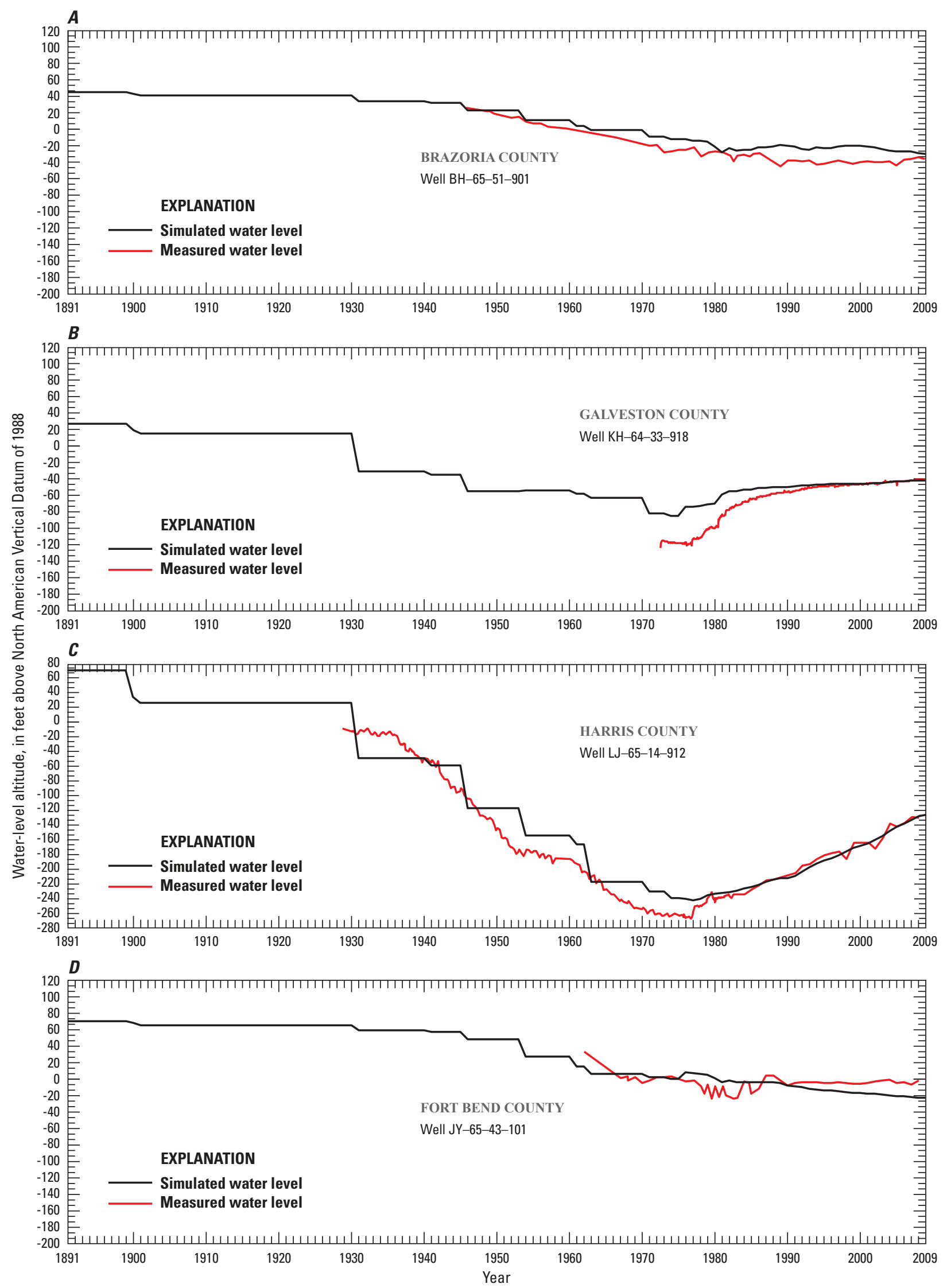

Figure 26. Hydrographs showing simulated and measured water levels in selected observation wells screened in the Chicot aquifer in $A$, Brazoria, $B$, Galveston, $C$, Harris, and $D$, Fort Bend Counties in the Houston Area Groundwater Model study area. 

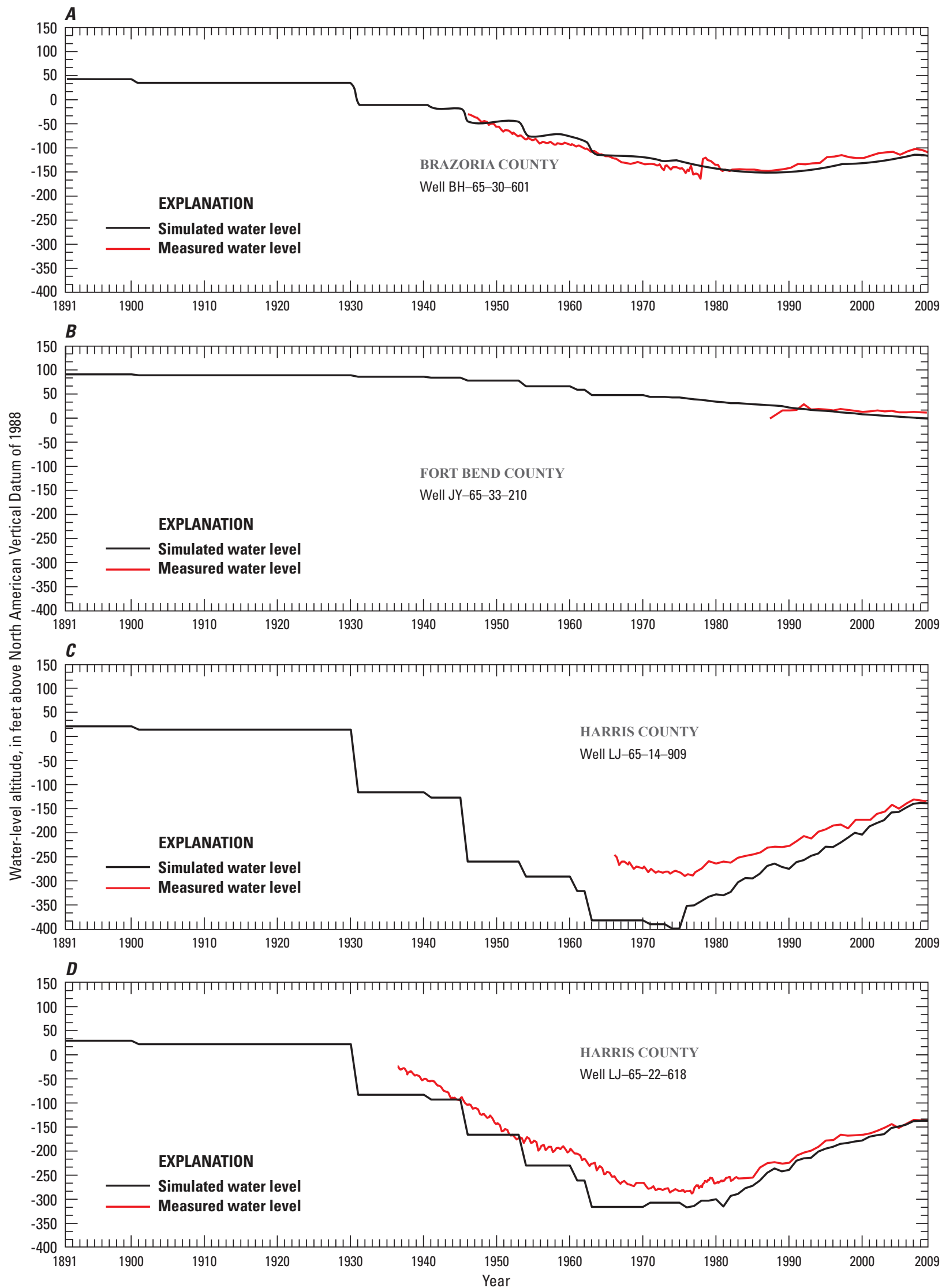

Figure 27. Hydrographs showing simulated and measured water levels in selected observation wells screened in the Evangeline aquifer in $A$, Brazoria, $B$, Fort Bend, and $C, D$, Harris Counties in the Houston Area Groundwater Model study area. 

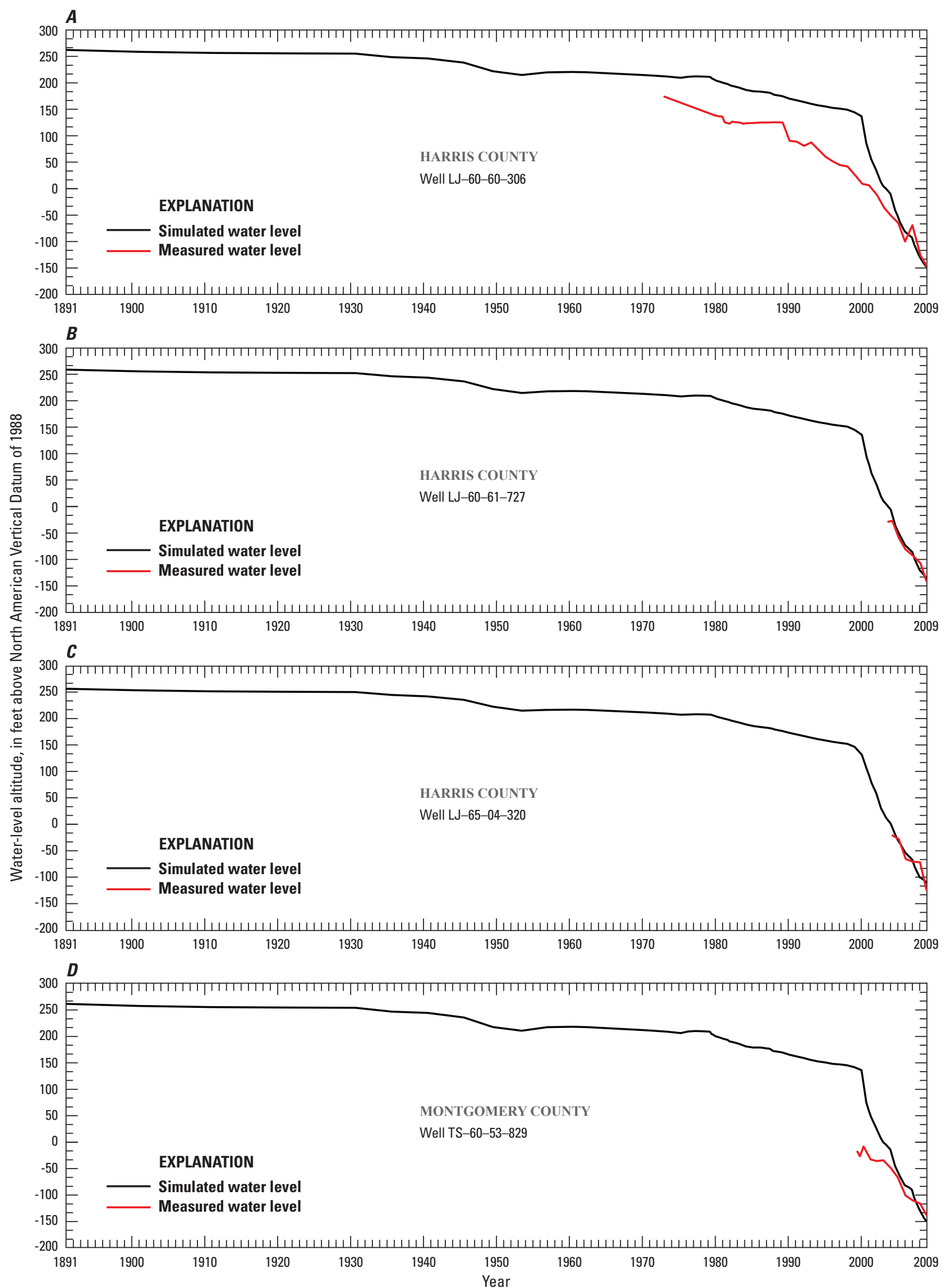

Figure 28. Hydrographs showing simulated and measured water levels in selected observation wells screened in the Jasper aquifer in $A, B, C$, Harris and $D$, Montgomery Counties in the Houston Area Groundwater Model study area. 


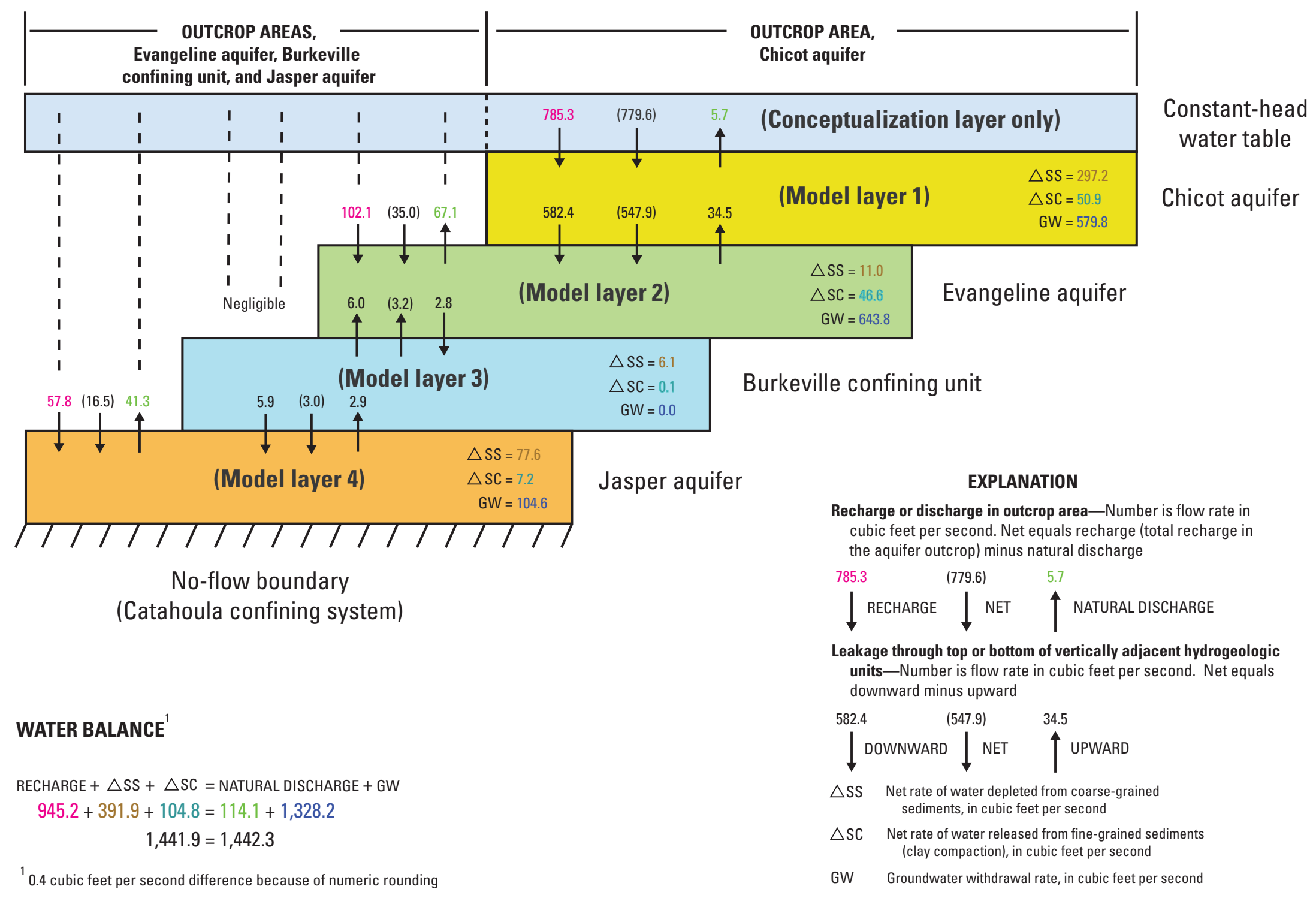


Table 4. Volumetric budget for the Houston Area Groundwater Model at the end of stress period 78, 2009.

[ft ${ }^{3} /$ day, cubic feet per day; E, exponent]

\begin{tabular}{|c|c|c|c|c|c|}
\hline $\begin{array}{c}\text { Cumulative } \\
\text { volumetric budget }\end{array}$ & $\begin{array}{l}\text { Sand } \\
\text { storage }\end{array}$ & $\begin{array}{l}\text { Groundwater } \\
\text { withdrawal }\end{array}$ & $\begin{array}{c}\text { Recharge and } \\
\text { natural discharge }\end{array}$ & $\begin{array}{l}\text { Clay } \\
\text { storage }\end{array}$ & $\begin{array}{l}\text { Total } \\
\text { volume }\end{array}$ \\
\hline Volume inflow ( $\mathrm{ft}^{3} /$ day) & $1.000 \mathrm{E}+12$ & $0.000 \mathrm{E}+00$ & $7.690 \mathrm{E}+13$ & $4.414 \mathrm{E}+11$ & $7.834 \mathrm{E}+13$ \\
\hline Volume outflow ( $\mathrm{ft}^{3} /$ day $)$ & $5.562 \mathrm{E}+10$ & $2.580 \mathrm{E}+12$ & $7.570 \mathrm{E}+13$ & $5.234 \mathrm{E}+09$ & $7.834 \mathrm{E}+13$ \\
\hline Cumulative volumetric percent error & & & & & 0.00 \\
\hline \multicolumn{6}{|c|}{2009 volumetric budget } \\
\hline Volume inflow ( $\mathrm{ft}^{3} /$ day $)$ & $3.478 \mathrm{E}+07$ & $0.000 \mathrm{E}+00$ & $8.166 \mathrm{E}+07$ & $9.102 \mathrm{E}+06$ & $1.255 \mathrm{E}+08$ \\
\hline Volume outflow ( $\mathrm{ft}^{3} /$ day $)$ & $9.166 \mathrm{E}+05$ & $1.148 \mathrm{E}+08$ & $9.859 \mathrm{E}+06$ & $4.233 \mathrm{E}+04$ & $1.256 \mathrm{E}+08$ \\
\hline 2009 volumetric percent error & & & & & -0.03 \\
\hline
\end{tabular}

An additional approach of simulating subsidence in Harris, Galveston, and Fort Bend Counties was the use of PRESS models developed by Helm (1975; 1976a, b; 1978). This model solves the Terzaghi equations of consolidation based on constant, one-dimensional total stress and transient changes of pore pressure at specific sites (Kasmarek and Strom, 2002). PRESS models were developed for 26 sites (fig. 32) by Freese and Nichols Inc. (Mike Reedy, Freese and Nichols Inc., written commun., 2011). For each PRESS site, a hydrograph was created by using coincident model cells of the simulated water-level data of the HAGM, and a value of subsidence was determined. A good correlation exists between the PRESS and HAGM simulated subsidence values. For example, the Pasadena site (fig. 32) indicates a PRESS determined subsidence value of $10.523 \mathrm{ft}$, and immediately adjacent to that site is a HAGM-simulated isolated 10-ft contour. Because the PRESS site locations (shown as polygons on fig. 32) encompass numerous model cells and may or may not extend across individual subsidence contours, a direct cell-by-cell or contour comparison is not a feasible evaluation. Instead, a more general areal comparison is appropriate.

\section{Sensitivity Analysis}

The sensitivity of calibrated model responses to changes in input data (the aquifer properties that control flow, recharge [general head boundary in the HAGM], discharge, subsidence, and storage, plus withdrawals) was evaluated. The values of selected model input data were iteratively and individually varied over ranges that may reflect plausible uncertainty (potential lack of accuracy of estimated or simulated values) in a series of simulations to present the effects of the uncertainty on simulated heads and subsidence. The effects of those changes on simulated 2009 water levels and land-surface subsidence were measured in terms of increases in RMSE (figs. 33 and 34, respectively). The plots depicting sensitivity of simulated water levels to changes in selected calibrated model input data (fig. 33) indicate that the model is more sensitive to groundwater withdrawals than to inelastic-clay storativity. In contrast, the plots depicting sensitivity of simulated land-surface subsidence to changes in selected calibrated model input data (fig. 34) indicate that the model is more sensitive to both groundwater withdrawals and sand storativity than to leakance. This analysis has implications if the HAGM is used for prediction of aquifer responses to future stresses. For example, the plots on figures 33 and 34 indicate that accurate estimates of withdrawals are more important to reliable predictions of heads and subsidence compared to accurate estimates of sand storativity.

\section{Model Limitations}

Several factors limit, or detract from, the ability of the HAGM to reliably simulate aquifer responses to groundwater withdrawals. The HAGM, like any nonlinear numeric model, is a simplification of the actual, complex aquifer system it simulates. As Brooks and others (1994) explain, simplification not only is necessary to make the problem tractable but also is necessary because the structure, properties, modeled boundaries, and stresses on the aquifer system can never be fully known. Simplifications involve assumptions about the actual system and the way it functions. Knowledge (or lack of knowledge) of the system is reflected in the quality and quantity of input data. The scale of the model, which is associated with the necessity to discretize a continuous system in space, also affects the ability of a model to produce reliable results. 


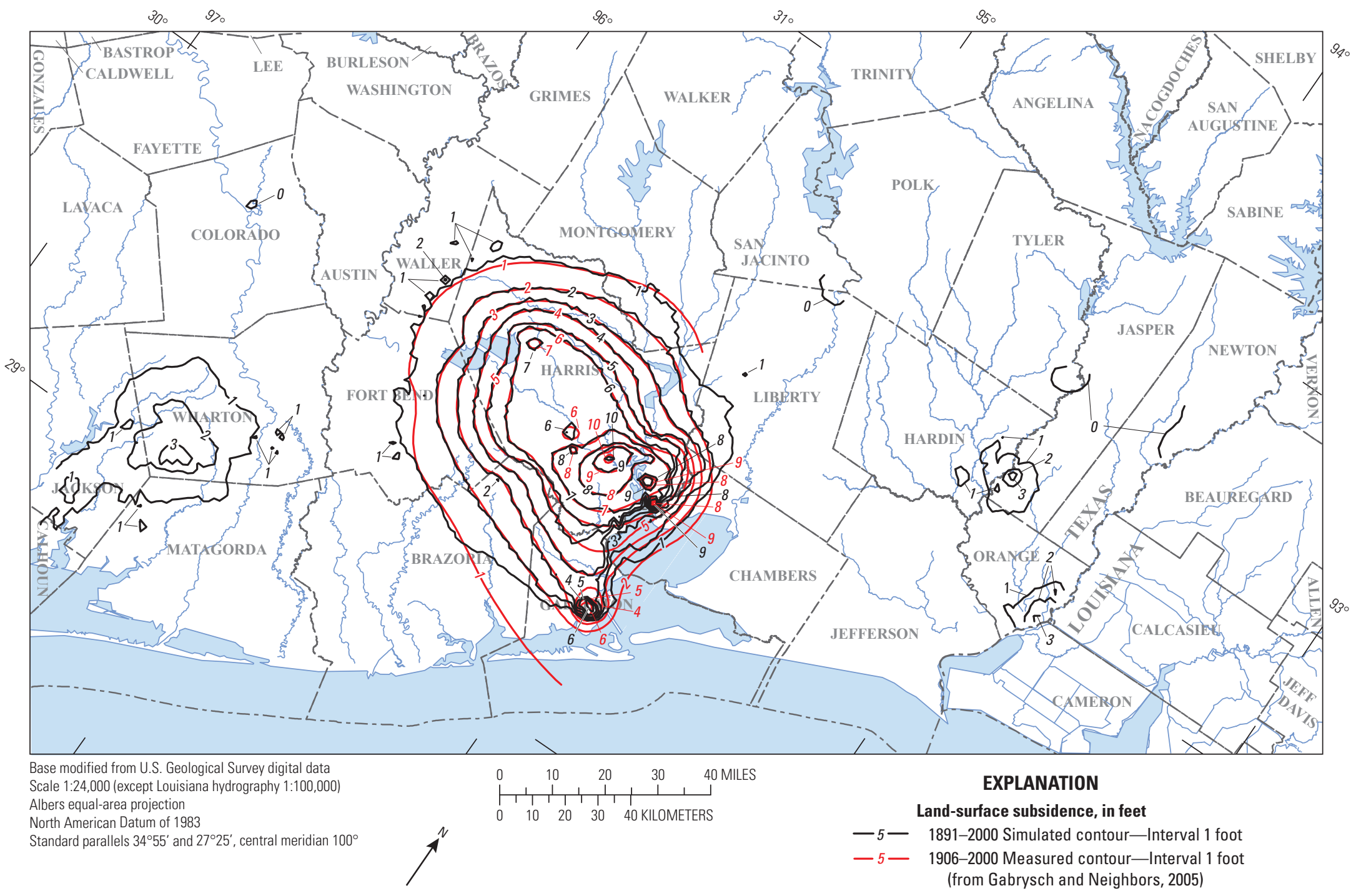




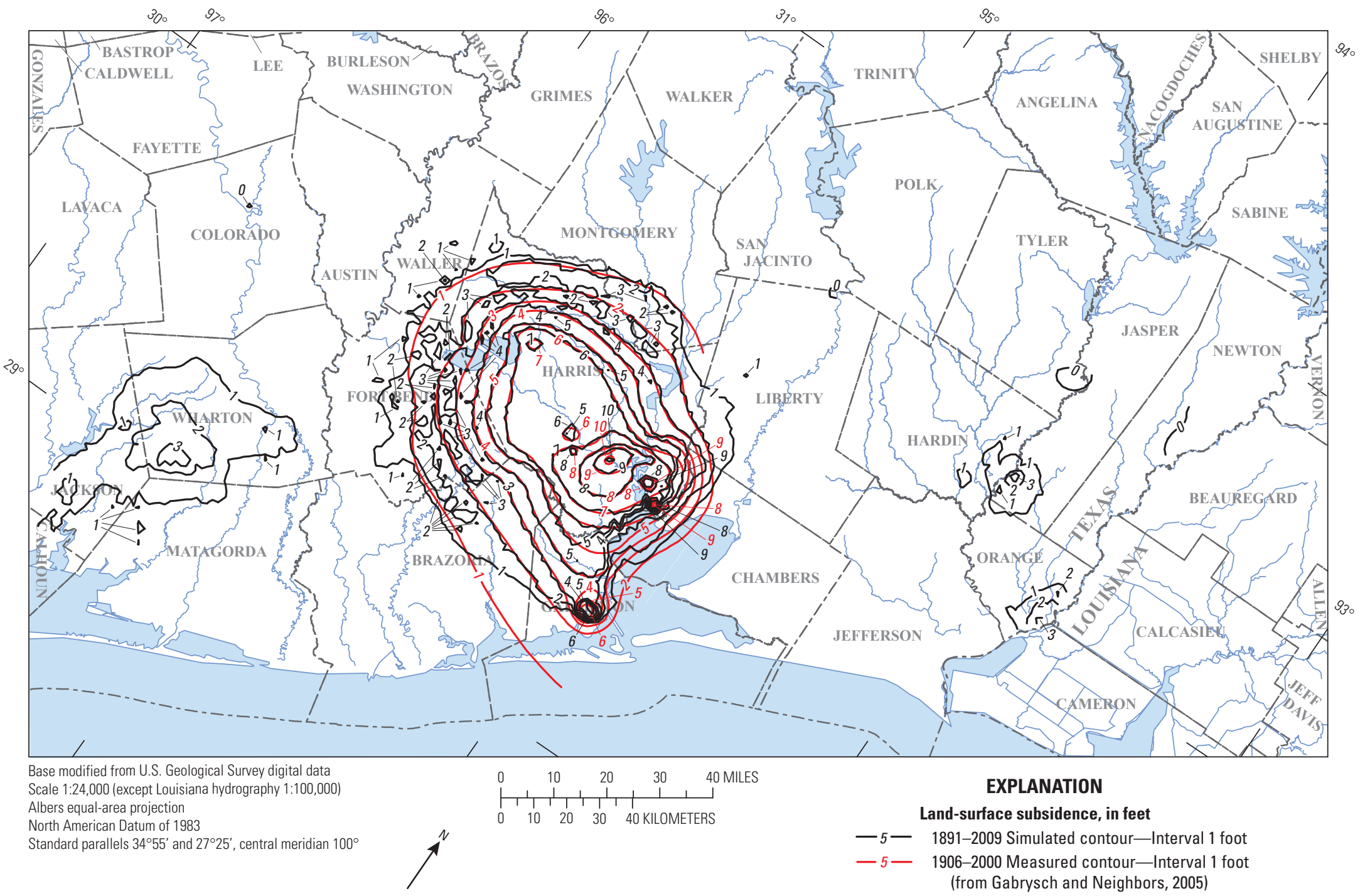

Figure 31. Simulated (1891-2009) and measured (1906-2000) land-surface subsidence in the Houston Area Groundwater Model study area. 


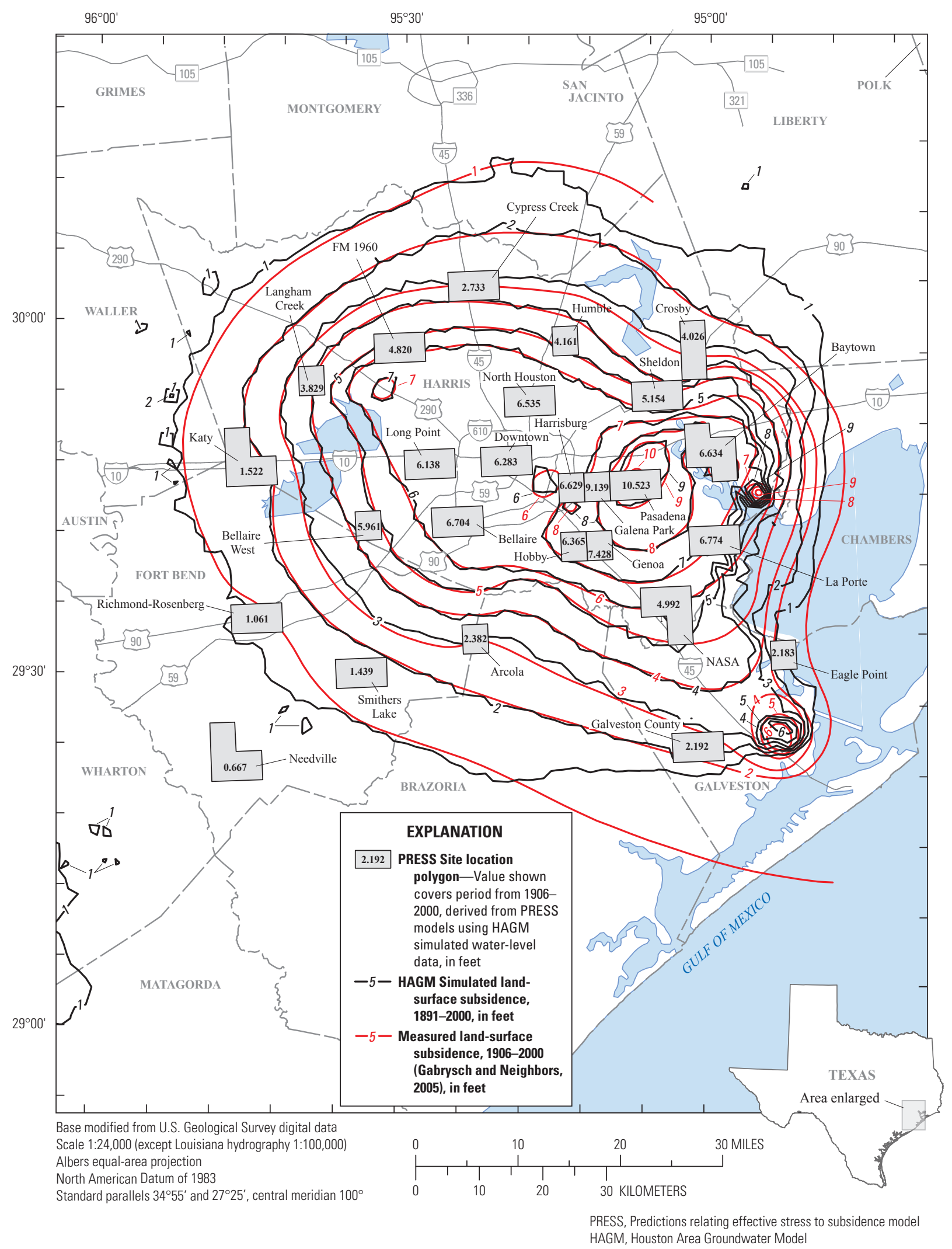

Figure 32. Predictions Relating Effective Stress to Subsidence (PRESS) model site locations and PRESS simulated land-surface subsidence, 1906-2000 (Mike Reedy, Freese and Nichols Inc., written commun., 2011), and Houston Area Groundwater Model simulated land-surface subsidence (1891-2009) and measured land-surface subsidence (1906-2000) in the Houston Area Groundwater Model study area. 


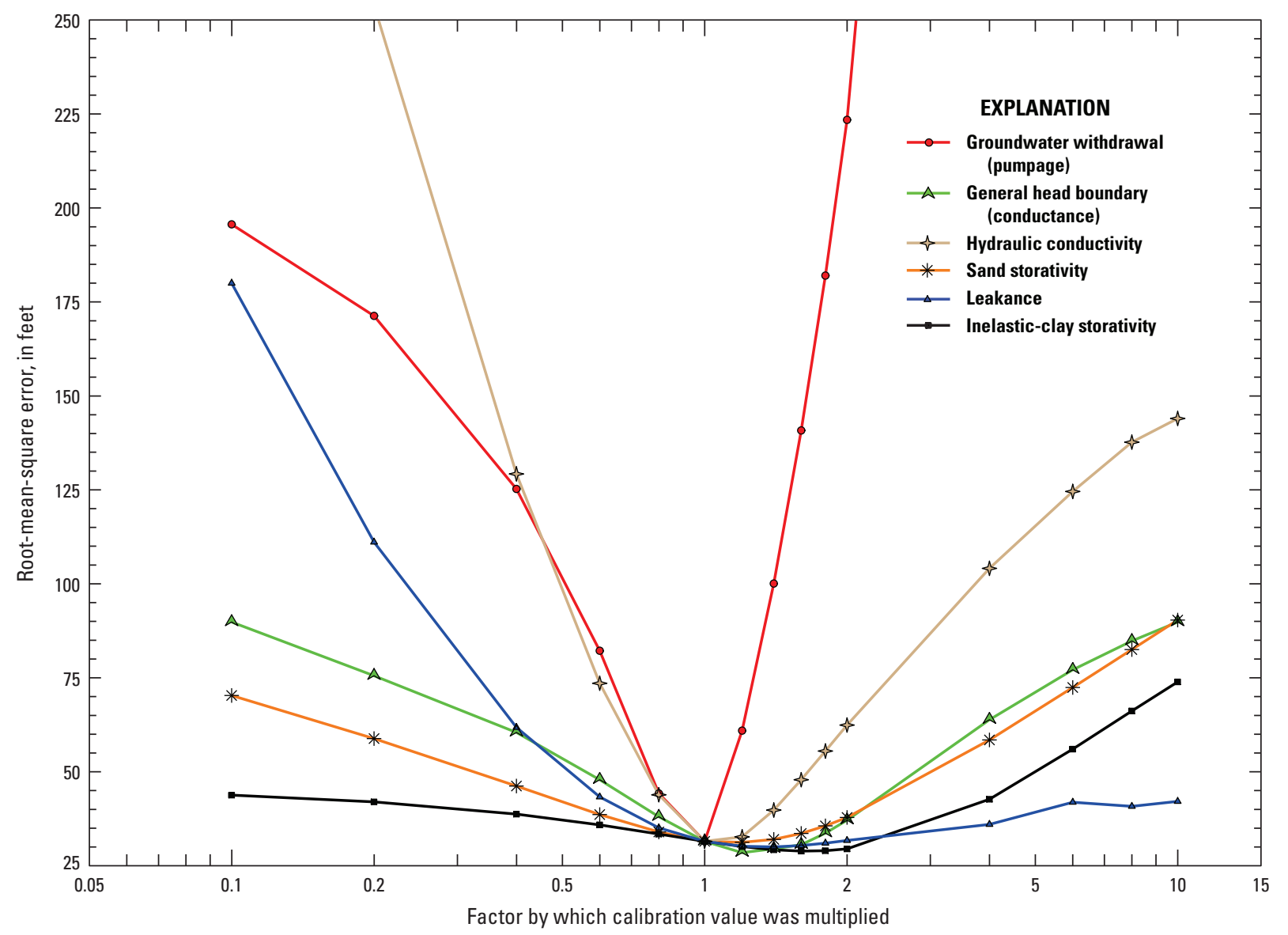

Figure 33. Sensitivity of simulated water levels to changes in selected calibrated model input data of the Houston Area Groundwater Model.

\section{Assumption}

A basic assumption is that the hydrogeologic units of the Gulf Coast aquifer system can be adequately represented by four discrete layers. This simplification is made because in the actual aquifer system the change from one aquifer to another with depth likely is transitional rather than abrupt. Other assumptions pertain to the boundary conditions. The conceptualization of the downdip boundaries of each hydrogeologic unit as the downdip limit of freshwater flow probably is realistic - salinity increases and flow becomes increasingly sluggish with distance downdip in each unit; however, the simplifying assumption that the downdip limit of freshwater flow in each unit is a sharp interface across which no flow occurs, the position of which is known and static over time, is more tenuous, as was discussed in the section "Hydrogeologic Units and Geologic Setting." The assumption of the southwestern and northeastern aquifer-system boundaries as no-flow, coincident with the Lavaca and Sabine Rivers, respectively, is not entirely realistic. Although those rivers likely represent effective groundwater-flow divides in the shallow subsurface, the vertical extent of their influence on groundwater flow is unknown. Those lateral boundaries are far enough from areas of major withdrawals, however, so that they likely have negligible influence on the simulated response of the aquifer to withdrawals. The base of the Jasper aquifer is assumed to be a no-flow boundary, although in the actual aquifer system, a relatively small amount of water probably flows between the Jasper aquifer and the underlying Catahoula confining system. Another assumption is that in areas of large withdrawals and substantial declines in the potentiometric surface of an aquifer, the overlying water table has not declined in response to increased downward gradients; water-table heads are held constant during simulations. If this assumption is not valid, then more recharge than actually occurs in the actual system could be simulated in such areas, which also could result in simulated heads higher than actual heads. Although the validity of this assumption has not been studied, that annual rainfall is likely sufficient to keep any actual long-term water-table declines to a minimum. As noted in the section on "Land-Surface Subsidence and Storage in Clays," assuming a constant-head water table also means constant geostatic pressure, which in turn makes changes in effective stress a function only of changes in head. If the 


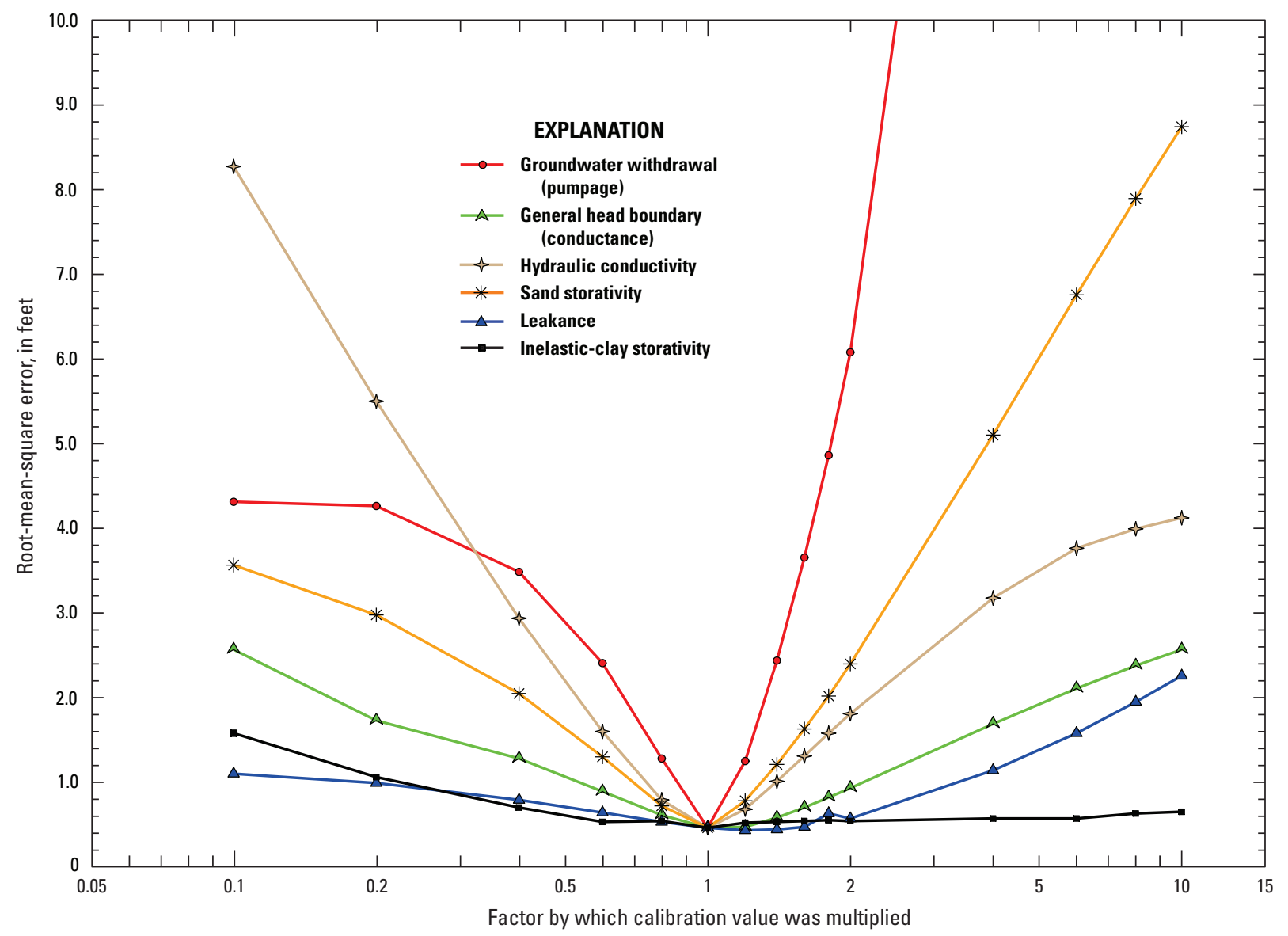

Figure 34. Sensitivity of simulated land-surface subsidence to changes in selected calibrated model input data of the Houston Area Groundwater Model.

assumption of a constant water table was not valid and the water table in the actual system was to decline appreciably, then the model could overestimate effective stress and thus overestimate compaction (subsidence). Also pertaining to the simulation of land-surface subsidence, the assumption was made that head changes within a model time step in the aquifer sands are the same as those in the interbedded clays; in other words, head changes in the clays do not lag those in the sands. If simulated time steps are too short to allow for dissipation of all excess-residual-pore pressure in the clays of the actual system, then the amount of water released by the clays in the simulated system will be unrealistically large for the time step. Leake and Prudic (1991, p. 7) provide an equation for the upper limit on the time required for excessresidual-pore pressure in the actual system to dissipate on the basis of interbedded clay properties, which can be compared to the length of model time steps. Computations for the interbedded clays in the aquifer system indicate that excessresidual-pore pressure will dissipate in about 300 days. Thus the 1-year model time steps that were applied for all of the transient period except for 1980, 1982, and 1988 appear to be adequate, but the 1-month model time steps during those
3 years probably are not, which implies that the simulated amount of water released by the clays for each of those 3 years probably is greater than the actual amount.

\section{Input Data}

Associated with each of the input datasets is a level of uncertainty and a degree of bias, neither of which is quantitatively known. The uncertainty arises from the fact that point measurements or estimates of the input data represent regions around the points. The bias originates from the facts that some properties are better known than others are and individual properties are better known in some areas than in others (data points commonly are concentrated in some areas and are sparse in others). The result is that the optimum (but non-unique) spatial distributions of input data arrived at through calibration, or history matching, are distributions of effective properties, not actual properties; that is, the set of property distributions for the calibrated model is one of potentially many plausible sets that would allow simulated heads, subsidence, and water-budget components to reasonably match those of the actual system under selected 
conditions. In all likelihood, the property distributions reflect the order of magnitude of the actual-system properties but not the true distributions of the actual-system properties. For example, the simulated spatial distributions of hydraulic conductivity of the Chicot, Evangeline, and Jasper aquifers (figs. 9-11), while generally of the correct orders of magnitude, indicate larger values and generally more "definition" in areas coincident with large withdrawals. The distributions reflect the availability of more historical information for those areas and thus more attention to those areas during calibration. It is likely that if comparable groundwater development, subsurface information, head data, and calibration attention were focused on the system in other parts of the HAGM study area, the distributions of hydraulic conductivity in those areas would reflect that situation and be different from the distributions of figures 9,10 , and 11 . What can be said about the spatial distributions of aquifer-system properties after calibration is that, collectively, they are one set of probably multiple sets of input data that allows the model to reasonably reproduce selected historical heads, land-surface subsidence, and groundwater flow. The possibility of multiple sets of input data implies that the reliability of the model for predictive simulation is uncertain.

\section{Scale of Application}

The HAGM is a regional-scale model, and as such, it is intended for regional-scale rather than local-scale analyses. Discretization of the HAGM area into 1- $\mathrm{mi}^{2}$ grid blocks in which aquifer properties and conditions are assumed to be averages over the area of each grid block precludes sitespecific analyses. For example, the simulated head in a grid block encompassing one or more pumping wells will represent an average head in the actual grid-block area rather than the head at or near the pumping well, which is much lower. An implication of simulated areal average heads is that, for calibration, comparison of simulated heads to measured heads might not always be comparable. Although explicit care is taken to ensure that static (nonpumping) water-level data are collected, undoubtedly some measured heads are influenced by nearby pumping or by antecedent pumping conditions or for other reasons are not representative of an average head in the grid-block area. Another scale-related issue - the "scale problem" as defined by Johnston (1999) — was described in the "Groundwater-Flow Conditions, Recharge, and Discharge" section. Because flow that enters and exits the actual system within the area encompassed by a single grid block cannot be simulated except by superposition of sources or sinks, which would be impractical over a regional area, the model does not simulate total recharge (and thus total [actual-system] groundwater flow). The fraction of total flow simulated is unknown, but the fraction of total flow simulated decreases as the grid-block size increases. This unknown flow fraction implies that any simulated components of flow not explicitly specified (for example, natural recharge and discharge) will be less than their actual-system counterparts. Explicitly specified components (for example, withdrawals) are based on measured or estimated actual-system data and therefore will more closely approximate actual-system magnitudes.

\section{Summary}

The availability of groundwater for municipal, industrial, and agricultural uses, as well as the potential subsidence associated with groundwater use, has been a concern in the Houston, Texas, area for decades. In cooperation with the Harris-Galveston Subsidence District, Fort Bend Subsidence District, and Lone Star Groundwater Conservation District, the U.S. Geological Survey developed and calibrated the Houston Area Groundwater Model (HAGM). Groundwater flow and land-surface subsidence in the northern part of the Gulf Coast aquifer system in Texas from predevelopment (before 1891) through 2009 were simulated; the objective of the HAGM is to accurately simulate and provide reliable, timely data on groundwater availability and land-surface subsidence in the Houston area through 2009. Results from the HAGM can be used to simulate aquifer response (changes in water levels and clay compaction) to future estimated water demands.

In a generalized conceptual model of the Gulf Coast aquifer system, the fraction of precipitation that does not evaporate, transpire through plants, or run off the land surface to streams enters the groundwater-flow system in topographically high updip outcrop areas of the hydrogeologic units in the northwestern part of the system. Most precipitation infiltrating into the saturated zone flows relatively short distances through shallow zones and then discharges to streams. The remainder of the water flows to intermediate and deep zones of the system southeastward of the outcrop areas where it is discharged by wells (in the developed system) and by upward leakage in topographically low areas near or along the coast. Because groundwater flow was simulated in the HAGM only as far as the downdip limit of freshwater, only the parts of the hydrogeologic units containing freshwater are described in this report.

The HAGM was developed to simulate groundwater flow and land-surface subsidence in the northern Gulf Coast aquifer system (Chicot aquifer, Evangeline aquifer, Burkeville confining unit, and Jasper aquifer) from predevelopment (1891) through 2009. The finite-difference computer code MODFLOW-2000 was used in this application. The finitedifference grid for the numerical model covers 33,565 square miles in southeastern Texas and southwestern Louisiana. The model grid was rotated 37.6 degrees clockwise so that the orientation of the model closely coincides with the natural groundwater divides, model boundaries, and predevelopment and postdevelopment flow paths. The four layers of the model together contain 134,260 grid blocks. Each layer consists of 137 rows and 245 columns. Layer 1 represents the Chicot aquifer, layer 2 the Evangeline aquifer, layer 3 the Burkeville confining unit, and layer 4 the Jasper aquifer. The grid blocks are uniformly spaced with each model cell area equal to 
1 square mile. The MODFLOW General-Head Boundary package was used to simulate recharge and discharge in the outcrops of the Chicot, Evangeline, and Jasper aquifers and the Burkeville confining unit. This package allows the water table of an aquifer system to function as a head-dependent flux. Initial conditions, including heads and hydraulic properties, provided a starting point for the model simulation. The initial conditions for head and hydraulic properties were coincident with the calibrated groundwater flow model previously created (2004) for the northern Gulf Coast by the USGS and cooperators.

Simulation of land-surface subsidence (actually, compaction of clays) and release of water from storage in the clays of the Chicot, Evangeline, and Jasper aquifers and the Burkeville confining unit was accomplished by using the Subsidence and Aquifer-System Compaction package designed for use with MODFLOW-2000. Simulations were made under transient conditions from 1891 through 2009 for 78 withdrawal (stress) periods of variable length. Total groundwater withdrawals increased from an estimated 41 million gallons per day in 1891 to about 869 million gallons per day in 2009.

The HAGM was calibrated by an iterative trial-and-error adjustment of selected model input data (the aquifer properties that control water flow, recharge, discharge, and storage) in a series of transient simulations until the model output (simulated heads, land-surface subsidence, selected waterbudget components) reasonably reproduced field measured aquifer responses.

Calibrated model parameters from each layer within the GAM and HAGM were compared to identify any differences in values. Generally, the additional data available in the model area since the development of the GAM required substantial modification of GAM parameters, particularly in the Jasper aquifer, for a complete calibration. Maximum general-head boundary conductance in the Chicot aquifer was reduced by more than two orders of magnitude, whereas generalhead boundary conductance values in the other model layers remained unchanged. Inelastic-clay storativity maximum and minimum values varied slightly between the two models in the Chicot and Evangeline aquifers but were of a consistent magnitude. Minimum hydraulic conductivity values decreased about two orders of magnitude in the Chicot aquifer, increased less than an order of magnitude in the Evangeline aquifer, and increased about three orders of magnitude in the Jasper aquifer. Maximum hydraulic conductivity values decreased nearly two orders of magnitude in the Chicot and less than one order of magnitude in the Evangeline and Jasper aquifers. Spatial distributions of simulated parameters of specific storage and leakance were similar between the GAM and HAGM calibrated models.

Hydraulic conductivities of the Chicot aquifer ranged from $4.0 \times 10^{-3}$ to 39.91 feet per day (ft/d), with the larger values located in Harris, Fort Bend, Liberty, Chambers, Galveston, Wharton, Colorado Tyler, Jasper, and Newton Counties. Hydraulic conductivities of the Evangeline aquifer ranged from $3.9 \times 10^{-1}$ to $30.79 \mathrm{ft} / \mathrm{d}$, with largest values located in northeast Fort Bend County. Hydraulic conductivities of the Burkeville confining unit are coincident with values used in the GAM. Hydraulic conductivities of the Jasper aquifer ranged from $8.64 \times 10^{-1}$ to $21.23 \mathrm{ft} / \mathrm{d}$, with the larger values located in northern Harris and Montgomery Counties.

Simulated sand storativities of the Chicot and Evangeline aquifers $\left(2 \times 10^{-3}\right.$ to $1.56 \times 10^{-1}$ and $1 \times 10^{-3}$ to $1.82 \times 10^{-1}$, respectively) reflect aquifer conditions from confined to semiconfined to water table. Sand storativities of the Chicot and Evangeline aquifers generally are largest in the updip, outcrop areas where water-table conditions prevail. Storativities of the Burkeville confining unit are coincident with values used in the GAM. Storativities of the Jasper aquifer $\left(4.1 \times 10^{-6}\right.$ to $\left.2.01 \times 10^{-1}\right)$ are generally largest in the updip, outcrop areas associated with water-table conditions.

Because a large area of land-surface subsidence has been documented in Harris County and parts of Galveston, Fort Bend, Montgomery, Brazoria, Waller, Liberty, and Chambers Counties, only these areas of the HAGM can be considered calibrated for elastic- and inelastic-clay storativity. Inelasticclay storativities for the Chicot aquifer, the Evangeline aquifer, the Burkeville confining unit, and the Jasper aquifer range from $5.3 \times 10^{-6}$ to $1.49 \times 10^{-2}$, from $2.28 \times 10^{-7}$ to $1.49 \times 10^{-1}$, from $2.05 \times 10^{-6}$ to $9.24 \times 10^{-5}$, and from $1.0 \times 10^{-6}$ to $9.47 \times 10^{-4}$, respectively. A total of 474 sites located in Harris and surrounding counties were used to evaluate simulated subsidence compared to measured subsidence. After numerous iterative trial-and-error transient model simulations, the final land-surface subsidence RMSE was $0.37 \mathrm{ft}$.

The simulated potentiometric surfaces of the Chicot, Evangeline, and Jasper aquifers for 2009 indicate general agreement with the measured potentiometric surfaces. The RMSE of the three aquifer potentiometric surfaces for 2009 were $31.06 \mathrm{ft}$ for the Chicot aquifer, $33.73 \mathrm{ft}$ for the Evangeline aquifer, and $23.50 \mathrm{ft}$ for the Jasper aquifer. The RMSE were about 6, 5, and 4 percent, respectively, for the total range in simulated heads for the three aquifers, with a -0.03 percent water-budget discrepancy between the total simulated inflow and the total simulated outflow.

Hydrographs were used to compare simulated and measured water levels; selected water wells with screened intervals in the Chicot, Evangeline, and Jasper aquifers match closely relative to the ranges of water-level change. Simulated water budget components for 2009 indicate that a net recharge (total recharge minus natural discharge) of 779.6 cubic feet per second $\left(\mathrm{ft}^{3} / \mathrm{s}\right.$ ) (about 0.56 inches per year [in./yr]) in the Chicot aquifer outcrop, $35.0 \mathrm{ft}^{3} / \mathrm{s}$ (about $0.23 \mathrm{in}$./yr) in the Evangeline aquifer outcrop, negligible net recharge in the Burkeville confining unit outcrop, and $16.5 \mathrm{ft}^{3} / \mathrm{s}$ (about $0.07 \mathrm{in} . / \mathrm{yr}$ ) in the Jasper aquifer outcrop. For the entire system, the simulated total net recharge for 2009 was $831.1 \mathrm{ft}^{3} / \mathrm{s}$ (about $0.45 \mathrm{in}$./yr).

In Harris County and counties immediately adjacent, where the main area of subsidence has been measured, the 1891-2000 simulated subsidence matches closely with the 1906-2000 measured subsidence. As much as $10 \mathrm{ft}$ of 
subsidence has occurred in southeastern Harris County near the northern end of Galveston Bay. A larger geographic area encompassing the maximum land-surface subsidence area and much of central to southeastern Harris County has subsided at least $6 \mathrm{ft}$. Again, in Harris County and counties immediately adjacent, where the main area of subsidence is present, the 1891-2009 simulated subsidence matches closely with the 1906-2000 measured subsidence, but not as closely as the simulated subsidence for 1891-2000. The most recent areas of subsidence are approximately located in southern Montgomery, northwest Harris, and Fort Bend Counties, where development has occurred and required sustained groundwater withdrawals during 2001-9.

An additional approach of simulating and predicting subsidence in Harris, Galveston, and Fort Bend Counties was the use of Predictions Relating Effective Stress to Subsidence (PRESS) model. For each PRESS site, a hydrograph was created by using coincident model cells of the simulated water-level data of the HAGM, and a value of subsidence was determined. A good correlation exists between the PRESS and HAGM simulated subsidence values. For example, at the Pasadena PRESS site, the simulated value is $10.523 \mathrm{ft}$ and the site is located immediately adjacent to a HAGM-simulated isolated $10 \mathrm{ft}$ contour.

The sensitivity of calibrated-model responses to changes in input data (the aquifer properties that control flow, recharge, discharge, subsidence, and storage, plus withdrawals) was evaluated. The HAGM sensitivity results indicate that accurate estimates of hydraulic conductivity and withdrawals are more important to reliable predictions of heads and subsidence compared to accurate estimates of sand storativity.

Several factors limit, or detract from, the ability of the HAGM to reliably predict aquifer responses to future conditions. The HAGM, like any nonlinear numeric model, is a simplification of the actual, complex aquifer system it simulates. Additionally, the HAGM is a regional-scale model, and as such, it is intended for regional-scale rather than localscale analyses. Discretization of the HAGM study area into 1 -square-mile grid blocks in which aquifer properties and conditions are assumed to be averages over the area of each grid block precludes site-specific analyses.

Associated with each of the input datasets are a level of uncertainty and a degree of bias, neither of which is quantitatively known. The uncertainty arises from the fact that point measurements or estimates of the input data represent regions around the points. The bias originates from the facts that some properties are better known than others are and individual properties are better known in some areas than in others (data points commonly are concentrated in some areas and are sparse in others). The result is that the optimum (but non-unique) spatial distributions of input data arrived at through calibration, or history matching, are distributions of effective properties, not actual properties; that is, the set of property distributions for the calibrated model is one of potentially many plausible sets that would allow simulated heads, subsidence, and water-budget components to reasonably match those of the actual system under selected conditions.

A basic assumption is that the hydrogeologic units of the Gulf Coast aquifer system can be adequately represented by four discrete layers, a simplification because, in the actual system, the change from one aquifer to another with depth likely is transitional rather than abrupt. Downdip salinity changes and lateral boundary conditions also are not absolutely known.

\section{References}

Ashworth, J.B., and Hopkins, Janie, 1995, Aquifers of Texas: Texas Water Development Board Report 345, 69 p.

Baker, E.T., Jr., 1979, Stratigraphic and hydrogeologic framework of part of the Coastal Plain of Texas: Texas Department of Water Resources Report 236, 43 p.

Baker, E.T., Jr., 1986, Hydrology of the Jasper aquifer in the southeast Texas Coastal Plain: Texas Water Development Board Report 295, 64 p.

Beckman, J.D., and Williamson, A.K., 1990, Salt-dome locations in the Gulf Coastal Plain, south-central United States: U.S. Geological Survey Water-Resources Investigations Report 90-4060, 44 p.

Brooks, R.J., Lerner, D.N., and Tobias, A.M., 1994, Determining the range of predictions of a groundwater model which arises from alternative calibrations: Water Resources Research, v. 30, no. 11, p. 2993-3000.

Carr, J.E., Meyer, W.R., Sandeen, W.M., and McLane, I.R., 1985, Digital models for simulation of groundwater hydrology of the Chicot and Evangeline aquifers along the Gulf Coast of Texas: Texas Department of Water Resources Report 289, $101 \mathrm{p}$.

Doyel, W.W., and Winslow, A.C., 1954, Pumpage of ground water and decline of artesian pressure in the Houston District, Texas, during 1951 and 1952: Texas Board of Water Engineers Bulletin 5401, 28 p.

Espey, Huston and Associates Inc., 1982, Phase II—Water management study: Prepared for Harris-Galveston Coastal Subsidence District, Friendswood, Texas [variously paged].

Federal Aviation Agency, 2007, Information for Operators: Accessed July 5, 2012, at: http://www.faa.gov/other_visit/ aviation_industry/airline_operators/airline_safety/info/ all_infos/media/2007/info 07008.pdf.

Fort Bend Subsidence District, 2010, Fort Bend Subsidence District 2003 regulatory plan: 14 p., accessed May 11, 2010, at http://www.fbsubsidence.org/assets/pdf/ FBRegPlan.pdf. 
Franke, O.L., Reilly, T.E., and Bennett, G.D., 1987, Definition of boundary and initial conditions in the analysis of saturated groundwater flow systems-An introduction: U.S. Geological Survey Techniques of Water-Resources Investigations, book 3, chap. B5, 15 p.

Freeze, R.A., and Cherry, J.A., 1979, Groundwater: Englewood Cliffs, N.J., Prentice-Hall, 604 p.

Fugro-McClelland (Southwest) Inc., 1997, Recalibration of PRESS models and development of two new models in Harris and Galveston Counties: Report no. 0401-3134 [variously paged].

Gabrysch, R.K., 1979, Approximate altitude of water levels in wells in the Chicot and Evangeline aquifers in the Houston area, Texas, spring 1977 and spring 1978: U.S. Geological Survey Open-File Report 79-334, 4 sheets.

Gabrysch, R.K., 1982, Ground-water withdrawals and changes in water levels in the Houston District, Texas, 1975-79: U.S. Geological Survey Open-File Report 82-431, 39 p.

Gabrysch, R.K., and Bonnett, C.W., 1975, Land-surface subsidence in the Houston-Galveston Region, Texas: U.S. Geological Survey in cooperation with the Texas Water Development Board Report 188, 18 p.

Gabrysch, R.K., and Neighbors, R.J., 2005, Measuring a century of subsidence in the Houston-Galveston region, Texas, USA, in Seventh International Symposium on Land Subsidence, Shanghai, P.R. China, October 23-28, 2005, Proceedings: p. 379-387.

Galloway, Devin, Jones, D.R., and Ingebritsen, S.E., eds., 1999, Land subsidence in the United States: U.S. Geological Survey Circular 1182, 177 p.

Halbouty, M.T., 1967, Salt domes-Gulf region, United States and Mexico: Houston, Gulf Publishing Co., 425 p.

Harbaugh, A.W., Banta, E.R., Hill, M.C., and McDonald, M.G., 2000, MODFLOW-2000, the U.S. Geological Survey modular groundwater model-User guide to modularization concepts and the groundwater flow process: U.S. Geological Survey Open-File Report 00-92, 121 p.

Harbaugh, A.W., and McDonald, M.G., 1996, User's documentation for MODFLOW-96, an update to the U.S. Geological Survey modular finite-difference groundwater flow model: U.S. Geological Survey Open-File Report 96-485, 56 p.

Harris-Galveston Subsidence District, 2012, Annual Groundwater Report 2012: accessed June 25, 2012, at http:// www.hgsubsidence.org/documents/index.html.

Helm, D.C., 1975, One-dimensional simulation of aquifer system compaction near Pixley, California-Part 1, Constant parameters: Water Resources Research, v. 11, no. 3, p. 465-478.
Helm, D.C., 1976a, Estimating parameters of compacting fine grained interbeds within a confined aquifer system for a one dimensional simulation of field observations, in Johnson, A.I., ed., Land subsidence: International Association of Hydrological Sciences, Publication 121, p. 145-156.

Helm, D.C., 1976b, One dimensional simulation of aquifer system compaction near Pixley, California-Part 2, Stress dependent parameters: Water Resources Research, v. 12, no. 3, p. 375-391.

Helm, D.C., 1978, Field verification of a one-dimensional mathematical model for transient compaction and expansion of a confined aquifer system, in 26th Hydraulic Division Specialty Conference on Verification of Mathematical and Physical Models in Hydraulic Engineering, College Park, Md., Aug. 9-11, 1978, Proceedings: American Society of Civil Engineers, p. 189-196.

Hoffman, J., Leake, S.A., Galloway, D.L., and Wilson, A.M., 2003, MODFLOW-2000 Groundwater Model-User guide to the Subsidence and Aquifer-System Compaction (SUB) Package: U.S. Geological Survey Open-File Report 03-233, $46 \mathrm{p}$.

Johnston, R.H., 1999 [revised], Hydrologic budgets of regional aquifer systems of the United States for predevelopment and development conditions: U.S. Geological Survey Professional Paper 1425, 34 p.

Jorgensen, D.G., 1975, Analog-model studies of groundwater hydrology in the Houston district, Texas: Texas Water Development Board Report 190, 84 p.

Kasmarek, M.C., 1997, Water-level altitudes in wells completed in the Chicot and Evangeline aquifers, Fort Bend County and adjacent areas, Texas, January-February 1990: U.S. Geological Survey Open-File Report 97-784, 2 sheets.

Kasmarek, M.C., Gabrysch, R.K., and Johnson, M.R., 2009, Estimated land-surface subsidence in Harris County, Texas, 1915-17 to 2001: U.S. Geological Survey Scientific Investigations Map 3097, 2 sheets.

Kasmarek, M.C., and Houston, N.A., 2007, Water-level altitudes 2007 and water-level changes in the Chicot, Evangeline, and Jasper aquifers and compaction 19732006 in the Chicot and Evangeline Aquifers, HoustonGalveston Region, Texas: U.S. Geological Survey Scientific Investigations Map 2968, 4 p., 18 sheets.

Kasmarek, M.C., Houston, N.A., and Ramage, J.K., 2009, Water-level altitudes 2009 and water-level changes in the Chicot, Evangeline, and Jasper aquifers and compaction 1973-2008 in the Chicot and Evangeline aquifers, HoustonGalveston region, Texas: U.S. Geological Survey Scientific Investigations Map 3081, 3 p., 16 sheets. 
Kasmarek, M.C., and Robinson, J.L., 2004, Hydrogeology and simulation of groundwater flow and land-surface subsidence in the northern part of the Gulf Coast aquifer system, Texas: U.S. Geological Survey Scientific Investigations Report 2004-5102, 111 p.

Kasmarek, M.C., and Strom, E.W., 2002, Hydrogeology and simulation of groundwater flow and land-surface subsidence in the Chicot and Evangeline aquifers, Houston area, Texas: U.S. Geological Survey Water-Resources Investigations Report 02-4022, 61 p.

LBG-Guyton Associates, 1997, Groundwater model review and conversion: Prepared for Harris-Galveston Coastal Subsidence District, Friendswood, Tex., 18 p.

Lang, J.W., and Winslow, A.G. (in collaboration with W.N. White), 1950, Geology and ground-water resources of the Houston district, Texas: Texas State Board of Water Engineers Bulletin 5001, 55 p.

Leake, S.A., and Prudic, D.E., 1991, Documentation of a computer program to simulate aquifer-system compaction using the modular finite-difference groundwater flow model: U.S. Geological Survey Techniques of WaterResources Investigations, book 6, chap. A2, 68 p.

Lone Star Groundwater Conservation District, 2010, Lone Star Groundwater Conservation District rules and bylaws: accessed May 11, 2010, at http://www.lonestargcd.org/ management_plan.html.

Loskot, C.L., Sandeen, W.M., and Follett, C.R., 1982, Groundwater resources of Colorado, Lavaca, and Wharton Counties, Texas: Texas Department of Water Resources Report 270, 240 p.

McDonald, M.G., and Harbaugh, A.W., 1988, A modular three dimensional finite-difference groundwater flow model: U.S. Geological Survey Techniques of Water-Resources Investigations, book 6, chap. A1, 586 p.

Meyer, W.R., and Carr, J.E., 1979, A digital model for simulation of groundwater hydrology in the Houston area, Texas: Texas Department of Water Resources Limited Publication LP-103, 133 p.

National Oceanic and Atmospheric Administration, 2012a, Tropical Storm Allison Heavy Rains and Floods Texas and Louisiana, June 2001: Accessed June 25, 2012, at http://www.nws.noaa.gov/os/assessments/pdfs/allison.pdf.

National Oceanic and Atmospheric Administration, 2012b, Comparative Climate Data for the United States Through 2011: Accessed June, 26, 2012, at http:/www.ncdc.noaa. gov/pub/data/ccd-data/CCD-2011.pdf.
Noble, J.E., Bush, P.W., Kasmarek, M.C., and Barbie, D.L., 1996, Estimated depth to the water table and estimated rate of recharge in outcrops of the Chicot and Evangeline aquifers near Houston, Texas: U.S. Geological Survey Water-Resources Investigations Report 96-4018, 19 p.

Riley, F.S., 1969, Analysis of borehole extensometer data from central California, in Tison, L.J., ed., Land subsidenceVolume 2: International Association of Scientific Hydrology, Publication 89, p. 423-431.

Ryder, P.D., and Ardis, A.F., 2002, Hydrology of the Texas Gulf Coast aquifer systems: U.S. Geological Survey Professional Paper 1416-E, 77 p.

State of Texas Drought Preparedness Plan, 2006, accessed June 24, 2012, at http://www.txdps.state.tx.us/dem/ CouncilsCommittees/droughtCouncil/droughtPrepPlan.pdf.

Strom, E.W., Houston, N.A., and Garcia, C.A., 2003a, Selected hydrogeologic datasets for the Chicot aquifer, Texas: U.S. Geological Survey Open-File Report 03-297, 1 CD-ROM.

Strom, E.W., Houston, N.A., and Garcia, C.A., 2003b, Selected hydrogeologic datasets for the Evangeline aquifer, Texas: U.S. Geological Survey Open-File Report 03-298, 1 CD-ROM.

Strom, E.W., Houston, N.A., and Garcia, C.A., 2003c, Selected hydrogeologic datasets for the Jasper aquifer, Texas: U.S. Geological Survey Open-File Report 03-299, 1 CD-ROM.

Tarver, G.R., 1968, Ground-water resources of Polk County, Texas: Texas Water Development Board Report 82, 109 p.

Trescott, P.C., 1975, Documentation of finite-difference model for simulation of three-dimensional groundwater flow: U.S. Geological Survey Open-File Report 75-438, 30 p.

Sandeen, W.M., 1972, Ground-water resources of Washington County, Texas: Texas Water Development Board Report $162,111 \mathrm{p}$.

Sellards, E.H., Adkins, W.S., and Plummer, F.B., 1932, The geology of Texas - Volume I, Stratigraphy: Austin, The University of Texas, Bureau of Economic Geology Bulletin 3232, 1,007 p.

Tóth, J., 1963, A theoretical analysis of groundwater flow in small drainage basins: Journal of Geophysical Research, v. 68 , no. 16 , p. $4795-4812$.

Verbeek, E.R., Ratzlaff, K.W., and Clanton, U.S., 1979, Faults in parts of north-central and western Houston metropolitan area, Texas: U.S. Geological Survey Miscellaneous Field Studies Map MF-1136, 1 sheet. 
Wesselman, J.B., 1967, Ground-water resources of Jasper and Newton Counties, Texas: Texas Water Development Board Report 59, $177 \mathrm{p}$.

Wesselman, J.B., 1972, Groundwater resources of Fort Bend County, Texas: Texas Water Development Board Report $155,176 \mathrm{p}$.

Williams, T.A., and Williamson, A.K., 1989, Estimating watertable altitudes for regional groundwater flow modeling, U.S. Gulf Coast: Ground Water, v. 27, no. 3, p. 333-340.

Williamson, A.K., Grubb, H.F., and Weiss, J.S., 1990, Groundwater flow in the Gulf Coast aquifer systems, south central United States-A preliminary analysis: U.S. Geological Survey Water-Resource Investigations Report 89-4071, $124 \mathrm{p}$.
Wood, L.A., 1956, Availability of ground water in the Gulf Coast region of Texas: U.S. Geological Survey unnumbered open-file report, $55 \mathrm{p}$.

Wood, L.A., Gabrysch, R.K., 1965, Analog model study of groundwater hydrology in the Houston district, Texas, with a section on Design, construction, and use of electric analog models, by E.P. Patten, Jr.: Texas Water Commission Bulletin 6508, 103 p.

Wood, L.A., Gabrysch, R.K., and Marvin, Richard, 1963, Reconnaissance investigations of the ground-water resources of the Gulf Coast Region, Texas: U.S. Geological Survey Open-File Report in cooperation with the Texas Water Commission, Bulletin 6305, 114 p. 

